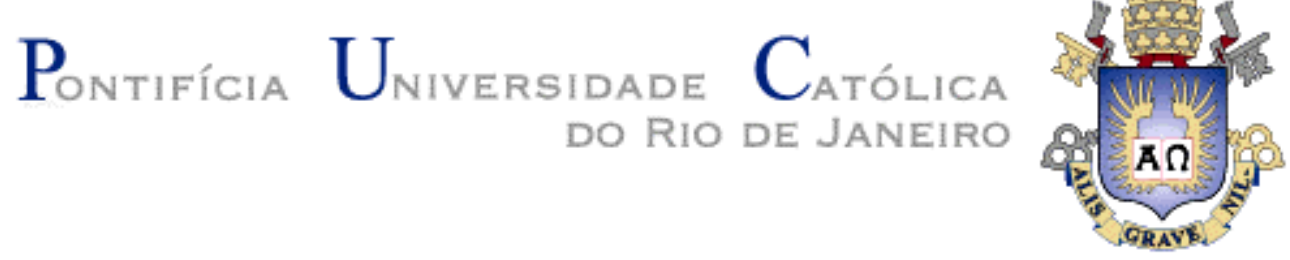

Vanessa Burjack Maranhão Gomes de Sá

\title{
Alinhamento cultural e socialização organizacional: um estudo de caso
}

Dissertação de Mestrado

Dissertação apresentada ao Programa de Pós-graduação em Administração de Empresas da PUC-Rio como requisito parcial para obtenção do grau de Mestre em Administração de Empresas.

Orientadora: Prof. ${ }^{a}$ Patrícia Amélia Tomei

Rio de Janeiro

Novembro de 2012 


\title{
Pontifícia U Uiversidade Católlica $_{\text {a }}$ \\ GRAVB:
}

Vanessa Burjack Maranhão Gomes de Sá

\begin{abstract}
Alinhamento cultural e socialização organizacional: um estudo de caso
\end{abstract}

Dissertação apresentada ao Programa de Pós-graduação em Administração de Empresas da PUC-Rio como requisito parcial para obtenção do grau de Mestre em Administração de Empresas. Aprovada pela Comissão Examinadora abaixo assinada.

Prof. - Patrícia Amélia Tomei Orientadora Departamento de Administração - PUC - Rio

Prof. - Flávia de Costa Neves Cavazotte IBMEC-Rio

Prof. Helio Arthur Reis Irigaray EBAPE/ FGV

Prof. a Mônica Herz Vice-Decana de Pós-Graduação do CCS - PUC-Rio 
Todos os direitos reservados. É proibida a reprodução total ou parcial do trabalho sem autorização do autor, do orientador e da universidade.

\section{Vanessa Burjack Maranhão Gomes de Sá}

Graduou-se em Administração de Empresas pelo Centro Universitário de Brasília - UniCEUB - em 2002. Atualmente, trabalha como administradora da Empresa Petróleo Brasileiro S.A. Pós Graduouse em Marketing de Serviços pela Upis Faculdades Integradas em maio de 2004 e em Avaliação da Gestão Pública pela Escola Nacional de Administração Pública - ENAP - em 2006.

Ficha Catalográfica

Sá, Vanessa Burjack Maranhão Gomes de

Alinhamento cultural e socialização organizacional: um estudo de caso / Vanessa Burjack Maranhão Gomes de Sá; orientadora: Patrícia Amélia Tomei. - Rio de Janeiro: PUC, Departamento de Administração, 2012.

136 f. ; $30 \mathrm{~cm}$

1. Dissertação (mestrado) - Pontifícia Universidade Católica do Rio de Janeiro, Departamento de Administração.

Inclui referências bibliográficas.

1. Administração - Teses. 2. Alinhamento cultural. 3. Valores. 4. Cultura. 5. Práticas de socialização. I. Tomei, Patrícia Amélia. II. Pontifícia Universidade Católica do Rio de Janeiro. Departamento de Administração. III. Título.

CDD: 658 


\section{Agradecimentos}

A Deus, por estar sempre ao meu lado, guiando minhas decisões e conduzindo-me para minhas realizações.

À minha família, pelo apoio e incentivo de todas as horas. Sem eles na minha vida, nada teria sentido e eu não seria a pessoa que sou hoje.

À orientadora Patrícia Tomei pela dedicação, perspicácia e parceria para a realização deste trabalho.

Aos 16 colegas de trabalho entrevistados, minha gratidão pela disponibilidade, informações e pelo interesse demonstrado.

À Empresa, objeto do meu estudo e, em especial, aos meus Gerentes Charles Nobre Peroba e Gilmar Pereira, pelo estímulo e apoio constantes.

A todos os amigos e conhecidos que contribuíram direta ou indiretamente para a realização deste estudo.

Aos meus colegas da PUC-Rio e a todos os funcionários do Departamento de Administração. 


\section{Resumo}

Sá, Vanessa B. M. Gomes de; Tomei, Patrícia Amélia. Alinhamento cultural e socialização organizacional: um estudo de caso. Rio de Janeiro, 2012. 136p. Dissertação de Mestrado - Departamento de Administração, Pontifícia Universidade Católica do Rio de Janeiro.

Este estudo teve como objetivo analisar se os valores transmitidos pela Companhia foram internalizados pelos empregados. Foi realizado um estudo de caso em uma empresa de economia mista cujo processo de recrutamento e seleção ocorre via concurso público. Os recém-chegados passam por um período de iniciação, conhecido por Ambientação, a partir do qual valores, comportamentos e normas da Empresa são transmitidos. Depois, participam do Curso de Formação com o objetivo de alinhar conhecimentos básicos e técnicos. Em seguida, ocorre a alocação efetiva na área, a partir da qual os empregados passam a ter contato mais direto com a cultura da Empresa. Durante este estudo, foram realizadas dezesseis entrevistas em profundidade, com empregados que já possuem aproximadamente seis anos de casa e que participaram juntos da Ambientação e do Curso de Formação, objetivando verificar se as táticas de socialização contribuíram para alinhar as expectativas dos empregados às necessidades da Empresa bem como os valores individuais aos valores organizacionais. Os principais resultados da pesquisa sugerem: a) com base nas expectativas dos entrevistados, os empregados ao aceitarem entrar na empresa, enxergavam que poderiam se encaixar no perfil desejável pela Companhia; b) com relação aos valores declarados explicitamente pela Companhia, especialmente, durante a Ambientação e o Curso de Formação, os entrevistados, em geral, compartilham desses valores. Nesse caso, o processo de socialização teve seu papel fundamental em prol do alinhamento cultural; c) com relação aos valores não explícitos, mas presentes na Cultura da Companhia há divergência entre os valores individuais e os organizacionais. A Companhia ainda que defenda que privilegia competências técnicas, transparência, mobilidade e meritocracia - na prática - apresenta práticas organizacionais diferentes do Discurso.

\section{Palavras-Chave}

Alinhamento Cultural; valores; cultura; práticas de socialização. 


\section{Abstract}

Sá, Vanessa B. M. Gomes de; Tomei, Patrícia Amélia (Advisor). Organization fit and socialization organizational: a case's study. Rio de Janeiro, 2012. 136p. MSc.Dissertation. - Departamento de Administração, Pontifícia Universidade Católica do Rio de Janeiro.

With this study, we try to analyze if the employees learned about the organizational values. A case's study was conducted in a Brazilian mixed economy Company, where the recruiting process occurs by a public contest. The new employees have to go through a period of initiation, known as "Ambientação", from which values, behaviors and rules are transmitted by the Company. Afterwards, they have a training course to get acquaintance with basic and technical issues. Then, they start working on a specific area where, for the first time, they really have contact with the Company's culture. During this study, there have been 16 in-depth interviews with the newcomers who have already worked for 6 years in the Company and attended the same training course when they joined the organization. These interviews were the instrument to measure if the socialization tactics were sufficient to achieve the expectations of the newly employees and the Company needs and also the individual values and organizational values. The results that were achieved suggest: a) based on the employees expectations, they figured that they could fit the company's employees profile; b) according to the Company's explicit values informed during "Ambientação" and the Training Course the employees accept these values. In this case, the socialization process was important to the cultural alignment; c) concerning the inexplicit values, there is some disagreement between individual and organizational values. The Company although defends technical practices, transparency, mobility and meritocracy really uses different organizational practices.

\section{Keywords}

Organization fit; values; culture; socialization tactics. 


\section{Sumário}

1. Introdução 11

1.1. Objetivo Final 12

1.2. Objetivos Intermediários 12

1.3. Relevância do Estudo 13

1.4. Delimitação do Estudo 13

1.5. Estrutura da Dissertação 14

2. Referencial Teórico 16

2.1. Valores Organizacionais 16

2.1.1. Conceituação 16

2.1.2. Estrutura dos Valores Organizacionais 18

2.1.3. Gestão de Valores 20

2.2. Cultura Organizacional 22

2.2.1. Definições de Cultura Organizacional 22

2.2.2. Níveis da Cultura organizacional 24

2.3. Alinhamento Cultural 25

2.3.1. Person-Organization Fit 25

2.3.2. Importância do Alinhamento Cultural 27

2.3.3. O Alinhamento Cultural e a Socialização 28

2.4. Socialização Organizacional 30

2.4.1. Socialização e Identidade Organizacional 33

2.4.2. Fases da Socialização 34

2.4.3. Estratégias de Socialização 35

3. Metodologia da Pesquisa 39

3.1. Tipo da Pesquisa 39

3.2. Estratégia de investigação 40

3.3. Seleção dos Entrevistados $\quad 40$

3.4. Coleta dos Dados 42

3.5. Tabulação e Análise dos Dados 42

3.6. Limitações do Método 43 
4. Descrição do Caso 45

4.1. Características Gerais 45

4.2. História da Empresa $X \quad 45$

4.3. Missão, Visão, Valores e Comportamentos Organizacionais 49

4.4. Objetivos Estratégicos de Recursos Humanos 51

4.5. Sobre a Universidade Corporativa Empresa X 52

4.5.1. O Programa de Formação de Empregados 53

4.5.1.1. Conceituação 54

4.5.1.2. Fases do Programa de Formação de Empregados 55

5. Discussão dos Resultados 58

5.1. Análise de conteúdo $\quad 58$

5.1.1. Período Anterior à Entrada Organizacional 58

5.1.2. Período da Ambientação e do Curso de Formação 66

5.1.3. Período entre a Alocação na Área até a data da entrevista 87

5.2. Análise do Programa de Formação de Empregados à luz das Teorias de Van Maanen 109

$\begin{array}{ll}\text { 6. Conclusão } & 118\end{array}$

7. Considerações Finais 125

8. Referências Bibliográficas 126 


\section{Lista de Quadros}

Quadro 1 - Perfil dos Respondentes 41

Quadro 2 - Valores e Comportamentos da Empresa X 90 


\section{Lista de Abreviaturas e Siglas}

\begin{tabular}{|c|c|}
\hline ABAST & Abastecimento \\
\hline BNDES & Banco Nacional de Desenvolvimento Econômico e Social \\
\hline CENAP & Centro de Aperfeiçoamento de Pesquisas de Petróleo \\
\hline \multirow[t]{2}{*}{ CENPES } & Centro de Pesquisas e Desenvolvimento Leopoldo Américo \\
\hline & Miguez de Mello \\
\hline CLT & Consolidação das Leis do Trabalho \\
\hline CNP & Conselho Nacional de Petróleo \\
\hline $\mathrm{E} \& \mathrm{P}$ & Exploração e Produção \\
\hline EDIHB & Edifício Horta Barbosa \\
\hline Fafen & Fábrica de Fertilizantes Nitrogenados \\
\hline FIRJAN & Federação das Indústrias do Estado do Rio de Janeiro \\
\hline GAPRE & Gabinete da Presidência \\
\hline GD & Gerenciamento de Desempenho \\
\hline GLP & Gás liquefeito de petróleo \\
\hline IVPO & Inventário de Perfis de Valores Organizacionais \\
\hline OCB & Organizational Citizenship Behavior \\
\hline OPEP & Organização dos países produtores de petróleo \\
\hline PLR & Participação nos Lucros e Resultados \\
\hline Procap & Programa de Capacitação Tecnológica em Águas Profundas \\
\hline PSP & Processo Seletivo Público \\
\hline REDUC & Refinaria Duque de Caxias \\
\hline RELAN & Refinaria Landulpho Alves \\
\hline RH & Recursos Humanos \\
\hline \multirow[t]{2}{*}{ SAP } & Sistemas, Aplicativos e Produtos para Processamento de \\
\hline & Dados \\
\hline SEPES & Serviço de Pessoal \\
\hline SMS & Segurança, Meio Ambiente e Saúde \\
\hline UFBA & Universidade Federal da Bahia \\
\hline UFRJ & Universidade Federal do Rio de Janeiro \\
\hline
\end{tabular}




\section{Introdução}

Os estudos recentes têm sugerido que o alinhamento entre as características do individuo e as da organização podem impactar o comportamento e as atitudes dos empregados. Quando as pessoas entram para uma organização, encontram valores similares ou não aos seus. Para as organizações, quanto maior o alinhamento entre os valores presentes na cultura organizacional e aqueles trazidos pelos novos entrantes, maiores as chances de aumentar a satisfação dos empregados, a eficácia organizacional bem como reduzir a rotatividade e o estresse.

Existe hoje uma grande preocupação das Empresas em buscar profissionais com valores alinhados aos da sua cultura organizacional, o que reforça a importância do tema: alinhamento cultural para as organizações. Muitas delas, em prol desse alinhamento, oferecem programas de socialização com vistas a divulgar a sua cultura para que os novos entrantes possam se adequar aos padrões de comportamento desejáveis por aquela empresa. Dessa forma, a socialização passa a ser o instrumento utilizado pelas organizações para transferir normas, valores, crenças e comportamentos aos novos empregados.

Van Maanen (1996) reforça esse entendimento na medida em que entende a socialização como um processo pelo qual o indivíduo aprende valores, normas de comportamentos esperados, que lhe permitem participar como membro de uma organização. Trata-se, então, de um processo que ocorre durante toda a interação do indivíduo com a organização, implicando também a renúncia de certas atitudes, valores e comportamentos.

No caso em questão, a Empresa utiliza o processo seletivo público como instrumento de recrutamento e seleção, e o seu processo de socialização tem o intuito de transferir valores, comportamentos e atitudes já que - via concurso público - a seleção privilegia a qualificação técnica do indivíduo, mas não o seu nível de alinhamento cultural com a organização. Dessa forma, o processo de socialização representa um papel importante para as organizações que buscam o alinhamento indivíduo-organização. 
Nessa linha, o presente estudo de caso tem por objetivo analisar se o processo de socialização da Empresa $X$ contribuiu para a internalização dos valores organizacionais sob a percepção dos empregados. Para tanto, far-se-á uma identificação das expectativas dos novos entrantes, identificação de que valores transmitidos pela Companhia foram internalizados, comparando-os às práticas organizacionais.

Será realizado um estudo de caso da Empresa X, uma sociedade de economia-mista, que seleciona seus empregados via processo seletivo público com ênfase em qualificação técnica, ou seja, embasado nos testes de múltipla escolha que avaliam a capacitação técnica do indivíduo que, por sua vez, somente após ter sido aprovado e convocado para tomar posse, apresenta o seu perfil cultural e suas competências. Para favorecer o alinhamento indivíduoorganização, a Empresa oferece aos empregados recém-chegados um período de socialização, conhecido por Programa de Formação de Empregados.

Nesse contexto, algumas questões que embasarão este estudo se originam: até que ponto os programas de socialização favorecem a internalização de valores? Como se internalizam nos públicos com subculturas diferentes as práticas, comportamentos e vivências dos valores discursados nos programas de socialização organizacional? A análise dessas questões será o objetivo deste trabalho que, com base em um estudo de caso de um grupo de empregados contratados há seis anos em uma organização, verificará se os valores transmitidos pela Companhia foram internalizados pelos empregados, comparando-os às práticas organizacionais.

1.1.

\section{Objetivo Final}

Para tratarmos do problema de pesquisa, este trabalho tem como objetivo final analisar se os valores transmitidos pela Companhia foram internalizados pelos empregados.

\section{2.}

\section{Objetivos Intermediários}


Para alcançar o objetivo final de pesquisa, é necessário primeiro delimitar os objetivos intermediários, dispostos a seguir:

- Identificar as expectativas dos empregados na época de sua entrada na Companhia;

- Identificar os valores organizacionais transmitidos pela Companhia;

- Conhecer que valores foram internalizados pelos empregados;

- Comparar valores presentes na Cultura da Companhia com as práticas organizacionais (Discurso x Prática);

- Classificar o processo de Socialização à luz das teorias de Van Maanen sob a percepção dos empregados que participaram do processo de socialização;

1.3.

\section{Relevância do Estudo}

O presente estudo poderá servir como fonte de consulta para empresas públicas e sociedades de economia mista que admitem pessoas via processo seletivo público e que buscam, por meio de programas para aculturação de $\underline{\text { membros, }}$ a transmissão de crenças, valores e normas com vistas à consolidação de um sistema único de valores institucionalizado.

O estudo também poderá servir como insumo para pessoas que pesquisam sobre alinhamento cultural e socialização organizacional na busca por um aprofundamento sobre o tema.

Alem disso, poderá contribuir para elucidar a importância e o papel das percepções dos indivíduos em relação às práticas de socialização, demonstrando que o indivíduo é membro-participativo e influenciador da cultura organizacional.

1.4 .

Delimitação do Estudo 
Estudos recentes demonstram a importância do gerenciamento cultural para as organizações. Para esse gerenciamento eficaz, conhecer, além das expectativas iniciais, os valores pessoais dos membros e os valores organizacionais é fundamental para se buscar o comprometimento dos funcionários e o alinhamento cultural.

Vale destacar que entre os processos que contribuem tanto para o gerenciamento quanto para o alinhamento cultural estão: o tipo de liderança da organização, estratégias e planos de ação, políticas de Recursos Humanos, sistemas de recompensas, planos de comunicação, mudanças conjunturais, entre outros. Neste trabalho, focar-se-á na socialização como um dos grandes influenciadores da cultura organizacional.

O processo de socialização, segundo Van Maanen e Shein (1979), é a forma como a aprendizagem ocorre e aquilo que as pessoas aprendem sobre o seu trabalho em organizações é freqüentemente resultado direto de como se dá esse aprendizado.

Esta pesquisa tem por objetivo principal investigar se os valores discursados pela Companhia foram internalizados pelos novos entrantes. Será estudada a influência do processo de socialização utilizado pela empresa na absorção dos valores organizacionais pela perspectiva dos empregados, ou seja, serão realizadas entrevistas com empregados que passaram pela Ambientação e pelo Curso de Formação há seis anos, buscando conhecer seus anseios iniciais e até que ponto os valores organizacionais foram absorvidos por eles.

Por outro lado, não consta no escopo deste estudo investigar questões relativas a comprometimento organizacional, identidade, significado do trabalho e clima organizacional.

Além disso, o enfoque qualitativo e subjetivo desta pesquisa não permite a generalização dos resultados para outros indivíduos da organização. Os resultados são representativos no âmbito do estudo proposto.

\section{5 .}

\section{Estrutura da Dissertação}


Esta dissertação está organizada em nove capítulos: O primeiro capítulo Introdução - contextualiza o problema que vai ser estudado, define os termoschave, objetivo final, objetivos intermediários, a relevância do estudo e a sua delimitação. No segundo capítulo - Referencial Teórico - é apresentada uma revisão da literatura sobre o tema em questão, incluindo conceitos relacionados a valores, cultura organizacional, alinhamento cultural e programas de socialização. O terceiro capítulo aborda e discute a metodologia da pesquisa: o tipo de pesquisa, estratégia de investigação, seleção de entrevistados, coleta, tabulação e análise dos dados e limitações do método. O capítulo 4 trata da empresa em questão: perfil, história, estratégia e demais características gerais, além de uma breve descrição do programa de formação de empregados (como ocorre a socialização dos novos membros). O capítulo 5 traz a análise de conteúdo com base nas entrevistas realizadas, fazendo-se referência às teorias de Van Maanen (1978, 1979, 1996). O capítulo 6 contempla as Conclusões do estudo; o capítulo 7, as Considerações Finais. No oitavo capítulo, são apresentadas as Referências Bibliográficas. E, por último, no nono capítulo, os Apêndices. 


\section{2.}

\section{Referencial Teórico}

\section{1.}

\section{Valores Organizacionais}

\subsection{1.}

\section{Conceituação}

A literatura mostra que entre os vários elementos presentes na cultura organizacional, os valores e crenças se destacam, podendo ser os valores considerados como a essência que orienta a vida da organização (TEVES, 2005). No caso de organizações com fortes culturas corporativas, os valores são considerados como regras, influenciando diretamente a rotina e as ações das pessoas, ou seja, os valores fazem uma declaração aberta da organização de como se espera que todos se comportem, inclusive os líderes e administradores. Quando isso acontece de fato, constrói-se uma cultura coesa que reforça a visão e a missão da empresa, e cada empregado se torna responsável pelo seu sucesso (BARRETT, 2000).

Para Tamayo, Mendes e Paz (2000) os valores podem ser definidos como princípios ou crenças, organizados hierarquicamente, relativos a estados de existência ou a modelos de comportamentos desejáveis que orientam a vida da empresa. Assim, valores são grandes influenciadores nos comportamentos e nas atitudes dos indivíduos (MEGLINO; RAVLIN, 1998). Ainda segundo Tamayo e Borges (2006), os valores organizacionais contêm três aspectos básicos:

- Aspectos cognitivos dos valores por constituírem parâmetros para julgar e justificar um comportamento individual e organizacional;

- Têm um forte componente motivacional, pois oferecem um sentido comum de direção a todos os empregados, facilitando a obtenção dos interesses e metas da organização; 
- Oferecem preferências por determinadas metas, estratégias e comportamentos.

Ratificando a sua importância para as organizações, Chatman $(1989,1991)$ e Bhargava e Mathur (2002), defendem que os valores organizacionais representam o núcleo da cultura organizacional, pois direcionam atitudes, julgamentos e comportamentos individuais, diferenciando uma organização da outra. Bhargava e Mathur (2002) acreditam que o sistema de valores existente em uma organização forma o fundamento da cultura organizacional, produzindo senso de direção para todos e guia para o comportamento de rotina dos membros.

Adicionalmente, Klenke (2005) entende os valores como a base para a geração de comportamentos que se adéquam às necessidades dos grupos, nos quais diferentes valores têm graus de importância diferenciados para cada indivíduo. Com base nisso, o autor enfatiza que valores são como construtos latentes envolvidos na avaliação de atividades ou resultados, tendo uma natureza geral e aplicável a vários níveis como nações, grupos e indivíduos.

No entanto, segundo Kabanoff e Daly (2002), vale diferenciar valores individuais de organizacionais. Os valores organizacionais são aqueles compartilhados e, em alguns casos, podem refletir as práticas organizacionais e, em outros casos, refletem o que as pessoas efetivamente acreditam que a sua organização é verdadeiramente, o que gostariam que a organização fosse ou o que gostariam que os acionistas acreditassem que a organização poderia ser.

Dessa forma, pode-se verificar que a clara percepção e o compartilhamento dos valores organizacionais pelas pessoas que nela atuam influenciam o comportamento a ponto de impactar na capacidade de motivação, criação e inovação do grupo e da organização e, conseqüentemente, na execução de suas estratégias (BARRETT, 2006).

Vale destacar que segundo Deal e Kennedy (apud FREITAS, 1991) os valores compartilhados definem o caráter fundamental da organização, aquilo que a diferencia das outras. Soma-se a isso o fato de Freitas (1991) pressupor a noção de compartilhamento como aquela em que não há uniformidade, mas sim convivência com os valores da organização quando esses são diferentes dos valores individuais (TROMPENAARS, 1994; HOFSTEDE, 1991; MORGAN, 1996; PETTIGREW, 1996). Valores organizacionais não são valores pessoais dos 
indivíduos, mas constituem valores das pessoas no que se refere ao funcionamento da organização: dizem respeito ao que um grupo dominante considera como ideal, aos princípios que devem orientar as ações organizacionais, na perspectiva desse grupo.

Com base nesse contexto, as definições sobre cultura organizacional tendem a um consenso com respeito ao fato de que os valores constituem um importante componente da cultura organizacional (MICHILOVA; HUTCHINGS, 2006). Nesta pesquisa, os valores compartilhados serão compreendidos como princípios relativos aos padrões desejáveis que orientam o dia a dia da Empresa.

\subsection{2.}

\section{Estrutura dos Valores Organizacionais}

Tamayo e Borges (2006), ao considerar que o ser humano se depara com necessidades de diversos tipos e que, mediante o desenvolvimento cognitivo e a socialização, coloca-as no mundo e se comunica com os outros, concluem que a fonte de valores pessoais e sociais é constituída de exigências universais do ser humano.

Da mesma forma, a organização tem pela frente exigências universais que devem satisfazer para poder subsistir. Essas exigências são classificadas em: a) a inevitável relação entre indivíduo e grupo; b) necessidade de uma estrutura que garanta a obtenção de metas e objetivos da organização; c) a relação da organização com o meio ambiente físico e social. Tamayo e Borges (2006) citam então o trabalho de Schwartz e Ros, com base nos valores culturais, que estabelecem três dimensões bipolares para responder às exigências. São elas:

A primeira dimensão é a autonomia versus conservadorismo. A autonomia implica perceber o indivíduo como entidade autônoma capaz de seguir seus próprios interesses e fixar metas em harmonia com os objetivos e regramentos da organização. Incluem-se, nesse pólo, a promoção de mudanças, as inovações e as transformações organizacionais. O pólo oposto, conservadorismo, consiste na preservação do status quo.

A segunda dimensão é regida pela hierarquia versus igualitarismo. O compromisso dos indivíduos com a missão e os objetivos da organização é obtido 
pela hierarquia, tendo como valores: a autoridade, a fiscalização, a supervisão e a influência. Por outro lado, uma estrutura igualitária tem por valores a justiça, a equidade e a responsabilidade.

A terceira dimensão leva em conta que toda organização necessita de matérias-primas para a elaboração de seus produtos e deve, então, optar por um determinado tipo de relação com o ambiente físico e social. Compreende a harmonia e o domínio. Valores como proteção à natureza, integração das organizações estão relacionados à harmonia. Já a interação desequilibrada via domínio de recursos materiais, do mercado e da tecnologia sem a preocupação ecológica constituem exemplos do pólo Domínio.

Para Oliveira e Tamayo (2004), os valores pessoais e organizacionais constituem em dois sistemas consolidados que podem entrar em confronto em razão da possibilidade de haver conflito entre os interesses individuais e os organizacionais. Por outro lado, Oliveira e Tamayo (2004) consideram que as teorias da área organizacional apresentam integração entre o empregado e o ambiente de trabalho como um fruto de um processo no qual os indivíduos devem se adaptar aos valores da organização. Assim, os autores construíram uma escala de valores organizacionais pautada nos valores pessoais denominada Inventário de Perfis de Valores Organizacionais - IPVO. Com relação ao IPVO, Oliveira e Tamayo (2004) sugerem que a estrutura de valores organizacionais corresponde à estrutura de valores pessoais e que os tipos motivacionais criados correspondem aos valores pessoais.

Sobre a teoria dos valores humanos de Schwartz (1992 apud OLIVEIRA; TAMAYO, 2004), os valores são representações cognitivas de três exigências humanas universais: necessidades biológicas do indivíduo; necessidades sociais de interação; necessidades sócio - institucionais de sobrevivência e de bem estar dos grupos (SCHWARTZ; BILSKY, 1987; SCHWARTZ, 1996 apud OLIVEIRA; TAMAYO, 2004). A partir dessas exigências, Schwartz (1992 apud OLIVEIRA; TAMAYO, 2004) desenvolveu uma tipologia contendo dez tipos motivacionais de valores, a saber: autodeterminação, estimulação, hedonismo, realização, poder, benevolência, conformidade, tradição, segurança e universalismo.

Enfim, os valores culturais auxiliam a sociedade a moldar as contingências às quais as pessoas devem se adaptar nas organizações onde trabalham. Em razão 
disso, os membros dos grupos culturais compartilham valores e são socializados para aceitá-los (OLIVEIRA; TAMAYO, 2004).

\subsection{3.}

\section{Gestão de Valores}

A literatura organizacional traz os valores organizacionais intrinsecamente relacionados à socialização de novos membros. Ao se definir socialização organizacional como um processo de aprendizagem do sistema de valores, normas e condutas da organização, possibilitando o ajuste de indivíduos ao seu ambiente de trabalho, enfatiza-se a estreita vinculação entre processos de socialização e de aprendizagem que compreendem os valores organizacionais como um de seus conteúdos básicos.

Tamayo e Gondin (1996 apud TAMAYO MENDES; PAZ, 2000) propõem que:

- O aspecto cognitivo dos valores organizacionais é considerado como elemento básico tendo em vista que, se são crenças sobre o que é desejável ou não para a organização, eles expressam as respostas dadas a problemas organizacionais.

- O aspecto motivacional refere-se ao fato de que os valores expressam interesses e desejos de alguém, constituindo-se, portanto, na expressão das metas fundamentais da organização. Os valores têm como função: criar modelos mentais semelhantes, relativos ao funcionamento e missão da organização, homogeneizando comportamentos e atitudes; contribuir para a construção da identidade social; atuar como mediadores de conflitos, contribuindo para a solução de problemas da organização. Valores são, portanto, as raízes das normas organizacionais, as quais podem ser consideradas como sua operacionalização. Finalmente, os valores estão organizados de forma hierárquica para indicar o grau de preferência por determinados comportamentos, metas ou estratégias, o que permite a distinção entre uma organização e outra (TAMAYO; MENDES; PAZ, 2000; OLIVEIRA; TAMAYO, 2004). 
A hierarquização dos valores organizacionais em vitais, relevantes e periféricos, usada por Schein (1968), para discutir o resultado do processo de socialização. Aos novos membros da organização, essa graduação permite algum grau de liberdade quanto à aderência ou à exigência de conformidade. Os valores vitais estão relacionados aos objetivos e estratégias da empresa, esperando-se a aderência a eles por parte de todos os membros da organização. Valores relevantes são aqueles que o indivíduo não tem necessidade de aceitar para se tornar membro da organização, mas cuja aceitação é desejável. Assim, um novo membro pode aceitar todos os valores e normas, assumindo uma postura de conformidade ou pode aceitar apenas os valores vitais e permanecer independente quanto aos demais. Para o autor, essa atitude seria de individualismo criativo ou poderia rejeitar todos os valores e normas, o que se configura como rebelião e resulta, na maioria das vezes, no desligamento do empregado, implicando como falha no processo de socialização.

A revisão da literatura leva à conclusão de que, para a compreensão e análise dos valores organizacionais, é preciso reconhecer que eles existem em dois níveis distintos. Tamayo e Gondim (1996 apud BORGES et al., 2002) classificam esses dois níveis, de acordo com a percepção dos funcionários, em real, para os valores que orientam concretamente a vida organizacional, especialmente no que diz respeito às decisões e à definição e aplicação de políticas; e o nível ideal, para os valores que os próprios funcionários crêem que a organização deve ou deveria seguir. Essa mesma visão de real e ideal, embora não baseada na percepção dos empregados, encontra-se em Van Rekom, Van Riel e Wirenga (2006). Para esses autores, as organizações expressam seus valores ideologicamente ou por meio de suas ações concretas, mas observam que os valores definidos pela ideologia não são necessariamente aqueles que efetivamente orientam o comportamento no diaa-dia.

Vale destacar ainda que, segundo Chatman \& Jehn (apud COOPERTHOMAS; ANDERSON; VAN VIANEN, 2004, tradução nossa), mudanças nas percepções iniciais dos indivíduos - durante o período da socialização - podem ser causadas por três mecanismos: 
a) Os valores individuais dos novos entrantes podem mudar como resultado da socialização, ou seja, ao se confrontarem com valores diferentes dos seus no ambiente de trabalho os indivíduos podem eventualmente adaptar os seus valores ao de outros.

b) A percepção inicial dos indivíduos quanto aos valores da organização pode mudar como resultado de suas experiências no trabalho.

c) Os valores organizacionais podem mudar com o tempo em resposta a eventos externos e internos.

\section{2.}

\section{Cultura Organizacional}

O estudo da cultura organizacional é importante porque tem relação direta com os resultados da organização. Quando a cultura de uma organização é conhecida, torna-se muito mais fácil trabalhar com as mudanças que podem prejudicar ou potencializar os objetivos e metas a serem atingidas, especialmente, nos processos de mudança em que pode haver rupturas no relacionamento entre a organização e os colaboradores. Nesses processos, é fundamental conhecer a cultura da organização para evitar barreiras e aproveitar oportunidades (JOHANN, 2006).

\subsection{1.}

\section{Definições de Cultura Organizacional}

Para o termo cultura organizacional, tendo em vista a sua abrangência, não existe consenso sobre a sua definição. A depender dos pressupostos básicos que os autores fazem de cultura e da própria organização (SMIRCICH, 1983), abordagens diferentes podem ser construídas. Por outro lado, grande maioria dos autores concorda que a cultura organizacional é holística, historicamente determinada, está relacionada com conceitos de antropologia, socialmente construída, flexível e difícil de ser alterada (HOFSTEDE, 1990).

No nível mais profundo, Pettigrew (1996) pensa a cultura como um conjunto complexo de valores, crenças e pressupostos que definem os modos pelos quais uma empresa conduz seus negócios. Tal núcleo de crenças e pressupostos básicos 
representa manifestos nas estruturas, sistemas, símbolos, mitos e padrões de recompensas dentro da organização. Nesse contexto, João Bilhim (2007) entende a cultura organizacional como: "a forma como se fazem as coisas aqui; normas, valores e crenças próprios de uma organização".

Considerando que para Tichy (1982) cultura organizacional é uma característica da organização e não de seus indivíduos, ela passa a ter o papel vital de unir os membros de uma organização em torno de um objetivo, sendo que a sua manifestação é mensurada pelo comportamento verbal e não verbal de seus indivíduos (HOFSTEDE, 1998). Nesse sentido, as práticas que estão disseminadas são apenas um reflexo da cultura organizacional (CHRISTENSEN; GORDON, 1999).

A cultura, conforme Mintzberg (2000), é essencialmente composta de interpretações de um mundo e das atividades e artefatos que refletem as mesmas. Além de cognitivas, essas interpretações são compartilhadas coletivamente em um processo social. Para o autor, não existem culturas particulares, pois sua essência é coletiva. Aktouf (1994) reforça esse entendimento já que para ele a cultura da empresa deveria ser "a reunião de tudo o que se faz a vida empresarial", "uma maneira diferente de designar um sistema informal generalizado, irracional e, talvez, profundamente subjetivo ou inconsistente". Somando-se às leituras anteriores sobre o tema, Morgan (1996) caracteriza cultura organizacional como a cola normativa que estruturaria o ambiente social e tornaria possível que as pessoas pudessem dar significado ao seu trabalho, trabalhassem confortavelmente com as outras e permanecessem focadas nas principais tarefas organizacionais.

Dessa forma, é possível compreender a cultura organizacional como coletiva, resultado de uma integração social, e associada ao comportamento das pessoas, à maneira como elas interagem com o ambiente, às normas formais $\mathrm{e}$ informais do grupo, aos significados compartilhados, aos símbolos e modelos mentais utilizados.

Formalmente Schein (1992, p.12) define cultura como:

[...] um padrão de conceitos básicos compartilhados que o grupo aprendeu como forma de resolver seus problemas de adaptação e integração interna, este padrão funcionou de forma satisfatória para ser considerado válido e para ser ensinado para os novos 
membros como a maneira correta de agir, pensar e sentir em relação a tais problemas.

O padrão de pressupostos básicos se refere a valores que regem o comportamento. Valores esses que vão sendo internalizados, tornando-se inconscientes a ponto de serem considerados naturais. Para Schein (1992), esses valores, crenças e certezas, quando aprendidos em conjunto, compartilhados e tidos como corretos são a essência da cultura. A abordagem apresentada por Schein (1992) mostra que o núcleo de certezas tácitas da cultura organizacional é composto por valores que até os próprios indivíduos muitas vezes desconhecem. Decifrar os padrões culturais pode ajudar a prever ou explicar comportamentos. Ainda segundo Schein (1992), a cultura faz parte de um grande processo de socialização do qual, por meio da interação entre os membros do grupo, os conceitos são transferidos, sedimentados e perpetuados. Com isso, a cultura é aprendida gradualmente pelos novos integrantes do grupo.

Com base nessas definições, o conceito de cultura organizacional que será considerado neste trabalho representa o conjunto de pressupostos e crenças comuns aos membros de uma organização, manifesto de forma explícita ou não, que implica a forma como uma empresa é administrada. Tal conjunto de pressupostos e crenças é passado de geração em geração pelos próprios membros da empresa, mas basicamente desenvolvido e disseminado pela alta gerência.

\subsection{2.}

\section{Níveis da Cultura organizacional}

Sobre a divisão dos níveis de uma cultura organizacional, podem variar desde as características superficiais ou visíveis até os traços mais profundos de uma cultura (a essência da cultura). Schein (1989) propõe a seguinte estrutura de níveis:

- Artefatos - Estrutura e processos organizacionais visíveis (difíceis de decifrar);

- Valores Patrocinados - Estratégias, objetivos e filosofias (justificativas patrocinadas); 
- Pressupostos Básicos Fundamentais - Inconscientes, crenças, percepções, pensamentos e sentimentos (mais profunda origem dos valores e ações).

Os artefatos compõem o nível mais superficial de uma cultura organizacional, incluindo todos os fenômenos visíveis, nem sempre facilmente decifráveis, dada a sua lógica implícita, de uma organização. Como por exemplo, local físico de trabalho, linguagem, tecnologia utilizada e produtos oferecidos, vestuário utilizado no dia-a-dia, mitos e estórias sobre a empresa, lista de valores e rituais.

Valores Patrocinados são os valores que se propagam e defendem por toda a organização, não visíveis, cuja origem é de um líder da companhia ou mesmo seu fundador. Esses valores só são internalizados, ou seja, tidos como crenças, após um "teste" dos mesmos. Isso quer dizer que não basta o valor ser dito, ele deve se mostrar eficaz.

Por fim, os Pressupostos Básicos Fundamentais são originados a partir de soluções que, repetidas vezes, se mostram eficazes para um dado problema, sendo o nível mais difícil de identificar e de se gerenciar. Não se questiona mais se pode ou não agir de determinada forma para um problema "x", se esse problema já surgiu diversas vezes e sempre se agiu da mesma forma, obtendo resultados positivos.

\section{3.}

\section{Alinhamento Cultural}

\subsection{1.}

\section{Person-Organization Fit}

Assim como os indivíduos têm personalidades identificadas mediante seus valores, crenças e comportamentos, os grupos ou organizações têm culturas que também são identificadas por meio de seus valores, crenças e comportamentos (BARRET, 2006). Quando as pessoas entram para uma organização encontram valores que podem ser similares ou não aos seus, ocorrendo o que o autor denomina de grau de "alinhamento de valores", variável que, segundo ele, impacta diretamente nos resultados da empresa. 
Nesse contexto, para Lopez e Mcmillan-Capehart (2009, tradução nossa), alguns estudiosos, tais como: Hoffman e Woehr, Kristof e Chatman defendem que o alinhamento indivíduo-organização influencia a satisfação no trabalho, a criatividade, o desempenho e os objetivos profissionais.

Vale ressaltar que o termo person-organization fit tem sido comumente utilizado como a adaptação mútua entre a pessoa e a organização. Para O’Reilly Chatman e Caldwell (1991), esse alinhamento indivíduo-organização pode ser definido como a congruência entre os valores individuais e aqueles pertencentes à organização. Chatman (apud BACKHAUS, 2003) reforça ainda que o alinhamento entre a pessoa e a organização ocorre mediante uma combinação entre valores individuais e organizacionais $\mathrm{O}$ entendimento de Wanous e Reichers (apud ACEVEDO; YANCEY, 2011, tradução nossa) é o de que o termo retrata o quanto um pessoa está alinhada à cultura da organização. Ratificando as leituras anteriores, Kristof (1996) conceitua o alinhamento como uma compatibilidade entre indivíduos e organizações. Ainda para ele, esse alinhamento ocorre quando há compartilhamento de características fundamentais similares.

Estudos prévios tem sugerido que esse alinhamento entre o indivíduo e a organização influencia o comportamento dos empregados. Kristof (1996, tradução nossa) reforça que o grau de congruência ou alinhamento entre as características dos empregados e as da organização podem impactar o comportamento e as atitudes dos empregados. Nessa linha e, segundo Boog, Casado e Dutra (2006), na medida em que as empresas explicitam os seus valores corporativos e os alinham à sua visão estratégica, estimulam a aderência do empregado e a sua identificação com os objetivos da empresa. Essa identificação se dá quando os empregados acreditam que a empresa corresponde a seus valores pessoais, facilitando o relacionamento de longo prazo entre empresa e indivíduo, o que leva à retenção dos talentos e à sustentação da carreira. As empresas mais sensíveis a esta realidade, têm investido um esforço maior na clarificação e transmissão de seus valores às pessoas, buscando os benefícios desta parceria de confiança, envolvimento e identificação (BARRETT, 2000).

Com base nos estudos sobre o tema, esta pesquisa compartilha do entendimento de que o termo person-organization fit representa a adaptação mútua entre o indivíduo e a organização, um alinhamento entre os valores do 
indivíduo e os valores da organização. Quando esse alinhamento ocorre, há chance de resultados benéficos para a parceria construída.

\subsection{2.}

\section{Importância do Alinhamento Cultural}

A cultura organizacional tem sido identificada como um importante aspecto do comportamento organizacional; um conceito que pode ser utilizado para se compreender o funcionamento das organizações (KRISTOF, 1996, tradução nossa). Já para O'REILLY (1989, tradução nossa), a cultura auxilia o indivíduo a se adaptar a uma determinada organização de forma que ele se sinta confortável. Se os potenciais candidatos aceitam ou não determinado trabalho, de certa forma significa que acreditam que se encaixarão naquela organização (CARLESS, 2005, tradução nossa).

Nessa linha, os estudos sobre alinhamento cultural também possuem grande importância para as organizações. Considerando que a cultura representa um sistema de valores compartilhados, o alinhamento cultural passa ser uma força integrativa que mantém a organização unida.

A compreensão da importância do alinhamento é compartilhada por Hofstede e outros (apud SILVERTHORNE, 2004, tradução nossa) já que para eles os valores individuais e as práticas organizacionais precisam ser integradas. Da mesma forma que as variáveis, tais como idade e gênero influenciam o grau de adequação indivíduo-organização. $\mathrm{O}$ alinhamento cultural está relacionado à forma como os membros de uma organização dão sentido ao contexto organizacional e aos fatores que influenciam esse processo de entendimento ou de compreensão de significado. Pesquisas sobre o tema têm sugerido que o alinhamento entre valores individuais e organizacionais resulta em benefícios tanto para o indivíduo quanto para as organizações.

O maior alinhamento cultural tem efeitos positivos e o desalinhamento aumenta a probabilidade de resultados negativos. Os fundamentos teóricos para esses efeitos são tipicamente atribuídos ao fato de que quanto mais alinhados à organização, especialmente com relação a valores, maior o nível de atração e 
menor a possibilidade de conflito (ELFENBEIN; O'REILLY, 2007, tradução nossa).

O ajuste entre pessoa-organização está associado a níveis decrescentes de rotatividade de pessoal e a altos níveis de satisfação no trabalho, comprometimento e atração (BOXX; ODOM; DUNN, 1991; CHATMAN, 1991; O'REILLY; CHATMAN; CALDWELL, 1991; POSNER, 1992; Schneider, 1987, tradução nossa). Ou seja, o grau de alinhamento entre o indivíduo e a organização está relacionado tanto à produtividade quanto à rotatividade de pessoal (ROUSSEAU; PARKS, 1992; RYAN; SCHMIT, 1996, tradução nossa).

Assim, para Silverthorne (2004, tradução nossa), o alinhamento de valores é importante em todas as culturas organizacionais já que compartilhar informações sobre a cultura antes de recrutar os empregados, usando-a como um guia para o processo seletivo resulta em um melhor alinhamento indivíduo-organização. Os resultados da sua pesquisa demonstraram que bom alinhamento indivíduoorganização impactou positivamente na satisfação no trabalho e no comprometimento organizacional e negativamente nas taxas de rotatividade de pessoal.

Vale ainda destacar que alguns estudos revelam que as pessoas preferem trabalhar em organizações que reflitam seus valores pessoais (CABLE; JUDGE, 1996; JUDGE; CABLE, 1997, tradução nossa).

\subsection{3.}

\section{O Alinhamento Cultural e a Socialização}

Os novos empregados entram nas organizações com expectativas específicas e freqüentemente positivas sobre o quão se encaixarão no novo trabalho e na nova organização. Suas experiências durante os meses iniciais são de suma importância para consolidar um bom alinhamento indivíduo-organização. Nesse sentido, podemos inferir que a cultura organizacional e a socialização influenciam a relação entre o individuo e a organização bem como os resultados dessa relação. (OSTROFF; KOZLOWSKI; WANOUS apud COOPER-THOMAS; ANDERSON; VANVIANEN, 2004, tradução nossa) 
Considerando essa relação, o controle de empregados resulta da combinação de dois elementos em destaque: a cultura organizacional e as táticas de socialização. Os valores organizacionais são transmitidos via processos de socialização e representam parte da cultura organizacional (OUCHI; MAGUIRE apud LOPEZ; MCMILLAN-CAPEHART, 2009, tradução nossa).

Conforme Shein (apud LOPEZ; MCMILLAN-CAPEHART, 2009, tradução nossa) a cultura, para ser considerada um mecanismo de controle, precisa ser transferida para os empregados. O’Reilly e Chatman (1986, tradução nossa), reforçam esse entendimento na medida em que consideram a cultura organizacional como uma forma de controle social, capaz de estabelecer que comportamentos e atitudes são mais ou menos apropriados para adoção pelos membros da organização.

Nessa linha, os processos de socialização representam o esforço da organização em direcionar o comportamento dos empregados em prol do alcance dos objetivos organizacionais. Anderson e Oliver (1987, tradução nossa) acreditam que os membros da organização podem ser socializados de forma que seus objetivos estejam mais alinhados com os objetivos da Empresa. Como conseqüência, os empregados buscarão não apenas atingir suas metas pessoais, mas também os objetivos organizacionais.

Vale destacar que os processos de socialização auxiliam os novos entrantes a entender normas, valores organizacionais e atitudes. Trata-se de um processo de aprendizagem, por meio do qual, os empregados aprendem sobre a cultura daquela organização.

Dessa forma, e segundo Cable and Parsons (2001, tradução nossa) a partir do entendimento da cultura os empregados passam a compreender que comportamentos são esperados perante novos desafios e novas situações. O principal resultado do processo de socialização organizacional passa a ser o alinhamento indivíduo-organização com relação à cultura e aos valores (CHATMAN, 1991, tradução nossa). Em outras palavras, a socialização organizacional busca o alinhamento cultural de forma que o novo entrante se sinta membro daquela organização.

Assim, a socialização torna-se fundamental para aquelas organizações que querem assegurar a continuidade dos valores centrais e normas. Quando os 
processos de socialização conseguem alinhar valores pessoais aos valores organizacionais, os novos entrantes tendem a estar mais comprometidos com a organização e menos dispostos a sair, garantindo retorno do que foi investido em recrutamento, seleção e treinamento.

No nível mais prático, Ge, Su e Shou (2010, tradução nossa) expõem no seu artigo que a socialização organizacional intervém para treinar os novos empregados sobre cultura organizacional e valores. É por meio desse treinamento que normas, habilidades e valores não ditos são aprendidos pelos novos entrantes. Adicionalmente, também representa um processo pelo qual a organização busca adequar os novos entrantes às regras e aos valores organizacionais de forma que adotem determinado comportamento esperado. Os resultados são influenciados tanto pela interação entre as táticas de socialização quanto pelas iniciativas ou pró-atividade dos empregados (ALLEN; MEYER, 1990; ASHFORTH; SAKS, 1996; JONES, 1986; MILLER; JABLIN, 1991; SAKS; ASHFORTH, 1997; KIM; CABLE; KIM, 2005, tradução nossa).

De outra forma, apesar da busca pelo alinhamento cultural ser desejável por grande parte das organizações, existe ainda a preocupação de que se perca a diversidade de idéias e perspectivas, tão necessárias ao ambiente empresarial competitivo atual. Lopez e McMillan-Capehart (2009) propõem em seu artigo que o alinhamento indivíduo-organização ocorra de forma a capitalizar as diferenças individuais ao mesmo tempo em que se cria comprometimento e lealdade nos empregados. Nesse caso, a cultura como controle social tornar-se-ia uma ferramenta para motivar pessoas a atingir os objetivos da organização sem anular suas características de adaptabilidade e criatividade.

\section{4.}

\section{Socialização Organizacional}

As organizações têm o objetivo de divulgar a sua cultura por meio de algum processo de socialização para que os colaboradores possam se adequar aos padrões de comportamento da empresa de maneira que venham a assimilar essa cultura, podendo assim desenvolver sua capacidade produtiva em benefício do desenvolvimento da organização. Isso é conseguido quando o processo de 
socialização é bem aplicado pela empresa e, conseqüentemente, bem absorvido pelos funcionários (SHINYASHIKI, 2003).

Esse entendimento é ratificado por Barge e Schlueter (apud ACEVEDO; YANCEY, 2011, tradução nossa) na medida em que para eles o processo de socialização é o primeiro passo para assegurar que os novos entrantes sejam integrados aos padrões da organização, enquanto constroem suas identidades individuais.

Para que um indivíduo recém-chegado a uma organização possa desempenhar suas funções futuras da forma esperada pela empresa, torna-se necessário uma preparação por parte da empresa. Em geral, os membros mais experientes servem como exemplo e fonte de aprendizagem para os mais jovens na organização. Quando um novo empregado chega a uma empresa, é exposto à maneira como se fazem as coisas, aprendendo sobre a empresa, além das tarefas que deverá desempenhar. Essa "aculturação" é conhecida por processo de socialização (FOGARTY, 2000).

De acordo com Van Maanen (1996), socialização organizacional é o processo pelo qual o indivíduo aprende valores, normas de comportamentos esperados, que lhe permitem participar como membro de uma organização. Este é um processo que ocorre durante toda a interação do indivíduo com a organização, implicando também a renúncia de certas atitudes, valores e comportamentos. Ainda, segundo Van Maanen (1978), socialização organizacional é entendida como a maneira pela qual os membros de uma organização estruturam as experiências iniciais de aprendizado de um individuo que assumirá uma nova posição organizacional, status ou papel dentro da organização. Tal aprendizado, segundo Menguc, Han e Auh, (2007), não está relacionado apenas às tarefas que serão desempenhadas por aquele indivíduo, mas sim a comportamentos e atitudes que assumirá na organização.

Assim, a socialização passa a ser considerada o processo de adaptação dos novos empregados à cultura da empresa e da empresa sobre o indivíduo. Conforme afirmava Feldman (1976), o processo de socialização é marcado pela assimilação da cultura e dos valores organizacionais; pelo ajuste ao grupo de trabalho e às normas do grupo e pelo desenvolvimento de habilidades necessárias para o trabalho. 
Tendo em vista que a socialização se refere ao processo pelo qual indivíduos adquirem atitudes, comportamentos e conhecimentos necessários para participar como membros da organização (BAUER; MORRISON; CALLISTER, 1998; VAN MAANEN; SHEIN, 1979), Louis (1980) ressalta a importância de se compreender detalhadamente o processo de socialização dos novos empregados. Uma vez conhecido o processo, há a possibilidade de desenvolver ações que alinhem as expectativas do empregado com a empresa e - dessa forma - reduza incertezas e melhore o rendimento do novo empregado.

Nessa mesma linha, a socialização na organização passa a ser uma questão de aprender as práticas; símbolos, heróis e rituais (HOFSTEDE et al., 1990). Os membros têm que seguir as práticas caso desejem se manter como membros, mas não precisam confessar quais são os seus valores (HOFSTEDE, 1998). Nesse caso, aqueles empregados que voluntariamente participam de programas de orientação são significativamente mais socializados com os objetivos, valores, história da organização do que aqueles que não participam, apresentando, inclusive, níveis mais altos de comprometimento organizacional (KLEIN; WEAVER apud ACEVEDO; YANCEY, 2011, tradução nossa).

Enfim, partindo-se do entendimento de que cultura é, no primeiro momento, o que é passado para as novas gerações, Shein (1992) entende que estudar a forma e conteúdo do que está sendo ensinado para os novos membros é uma boa maneira de descobrir alguns elementos da cultura. Não obstante, com esse tipo de análise, só é possível compreender a parte mais superficial da cultura porque o seu cerne não é revelado em regras de comportamento passadas instantaneamente para os novatos. O cerne da cultura só é apresentado ao novato quando ela passa a fazer parte de um determinado círculo do grupo no qual os segredos são compartilhados.

Nesse caso, a socialização representa o instrumento que as organizações utilizam para direcionar o comportamento dos novos em prol dos seus objetivos e necessidades. Destaca-se que, segundo Wanous e Reichers (2000, tradução nossa), ela não ocorre apenas naquelas semanas iniciais, pois se trata de um processo que permanece durante a carreira do empregado. 


\subsection{1.}

\section{Socialização e Identidade Organizacional}

Segundo Shein (apud GE; SU; SHOU, 2010, tradução nossa), a socialização organizacional envolve alguns elementos básicos relacionados à organização: objetivos e identidade e outros relacionados ao indivíduo: responsabilidades e padrões de comportamento.

Considerando que a socialização impacta tanto na organização quanto no indivíduo, a identidade da organização está intimamente ligada à identificação do membro àquela organização. Quando o indivíduo se define usando a identidade da organização, pode-se inferir que ocorreu uma identificação organizacional. Nesse caso, para Mael e Tetrick (1992, tradução nossa) os indivíduos tendem a se misturar com a organização a que pertencem e essa identificação envolve o compartilhamento de características típicas, virtudes e falhas.

Ratificando a leitura de Mael e Tetrick (1992), identificação com a organização se refere ao sentimento de pertencimento àquela organização (ASHFORTH; MAEL, 1989, tradução nossa). Forte identificação com a organização auxilia o indivíduo a se ver como membro daquela organização. Quando as pessoas se identificam com a organização, a sua sobrevivência fica interligada à sobrevivência da organização. Conseqüentemente, os empregados tendem a se focar em atividades que beneficiam a organização com um todo, e não naquelas de interesse próprio. Esse entendimento é conhecido na literatura como OCB - Organizational Citizenship Behavior (DUTTON; DUKERICH; HARQUAIL, 1994, tradução nossa).

Assim, pode-se inferir que a identificação com a organização é uma forma de contrato psicológico que ocorre quando os membros adotam as características da organização como suas. Essa identificação com a organização habilita os membros a contribuir mais freqüentemente e livremente com a organização, sendo que seus esforços em prol da organização resultam em comportamentos pautados em obediência, lealdade e participação ativa. 


\subsection{2.}

\section{Fases da Socialização}

O processo de socialização apresenta quatro fases: Antecipatória, Acomodação, Gerenciamento do Papel e Encerramento (FELDMAN, 1976).

A primeira fase consiste no aprendizado que ocorre antes do indivíduo entrar de fato na organização. Durante essa fase, o indivíduo constrói expectativas referentes ao trabalho por meio de conversas com pessoas que trabalham na empresa.

A segunda fase é denominada Acomodação. Nessa fase, o empregado passa a enxergar como a organização é realmente e tenta se tornar um membro participativo. Para se tornar esse membro, o empregado aprende novas tarefas, estabelece relacionamentos com os colegas de trabalho, identifica seu papel na organização e avalia seu progresso.

$\mathrm{Na}$ terceira fase, o empregado se depara com três tipos de conflitos: os que ocorrem dentro do seu grupo de trabalho; os que ocorrem entre o seu grupo de trabalho e outros grupos dentro da organização, tais como: conflitos por recursos para definir prioridades; e aqueles conflitos externos ao seu trabalho, por exemplo: conflitos entre a família e o trabalho que, por sua vez, ocorrem, normalmente, devido ao tempo e às mudanças na qualidade de vida.

Por fim, o processo de socialização se encerra com a avaliação da sua eficácia, ou seja, a última fase abrange os resultados da socialização, medidos a partir de quatro variáveis: satisfação geral, que identifica o quanto o empregado está feliz com o seu trabalho; a influência mútua, que mostra o quanto o empregado acredita ter controle sobre o trabalho do seu setor, isto é, o quanto ele conseguiu influenciar no modo como o trabalho é realizado; motivação interna para o trabalho, que representa o quanto o empregado é auto-motivado para desempenhar seu papel; e o envolvimento com o trabalho, que está relacionado a quanto o indivíduo está comprometido e envolvido com o seu trabalho (FELDMAN, 1976).

Ainda com base no discurso de Feldman (1976), há distinção entre uma socialização completa de uma bem sucedida. Para ele, a socialização se completa quando o indivíduo passa com sucesso por todas as fases. Todavia, mesmo que 
ainda não esteja completa, a socialização pode ser bem sucedida desde que o indivíduo esteja progredindo, isto é, consiga solucionar os conflitos da fase em que se encontra, passando de uma fase para outra. Com base em seus estudos, os programas organizacionais de socialização influenciam a satisfação geral dos trabalhadores e seu sentimento de autonomia e influência no trabalho. Por outro lado, o autor defende que nem o tipo de motivação interna nem o grau de envolvimento do empregado com o trabalho são influenciados pelo processo de socialização.

\subsection{3.}

\section{Estratégias de Socialização}

A abordagem dos primeiros estudos foi predominantemente funcionalista, pois objetivaram explicar como as organizações socializam seus membros. O estudo de Van Maanen é considerado emblemático e representa um dos pontos de partida para o desenvolvimento de modelos de socialização. Segundo ele, há sete pares de estratégias de socialização empregadas pelas empresas que não são mutuamente exclusivas e que, na prática, estão combinadas de diversas formas:

\section{a) Formais e Informais}

A estratégia formal de socialização prepara um novo membro para assumir um cargo específico dentro da organização. Quanto mais formal for a estratégia utilizada, mais o papel do novato é separado e especificado, e maior é a tensão sofrida pelo novo membro, o que vai influenciar as atitudes e valores deste. Em uma atmosfera informal, grande parte do aprendizado do novo membro necessariamente ocorre no interior das redes sociais e das tarefas que envolvem sua posição.

Dessa forma, a estratégia formal de socialização é apenas a primeira etapa da socialização. A segunda etapa ocorre quando o novo membro é colocado em seu cargo designado, devendo aprender informalmente as práticas reais em seu setor. 


\section{b) Individuais e Coletivas}

Na socialização coletiva, os novos membros são reunidos e processados pelas mesmas experiências, com resultados que tendem a ser relativamente parecidos. Quando um grupo é introduzido em um programa de socialização, ele pode desenvolver uma consciência coletiva, o que pode gerar comportamentos desfavoráveis, pois os indivíduos do grupo podem desenvolver interesses divergentes aos da organização.

Por este motivo, algumas organizações preferem utilizar estratégias individuais. As estratégias individuais, comparadas às coletivas, podem gerar resultados bem distintos, pois os colaboradores são socializados individualmente, e o processo de mudança vai depender da relação direta entre o agente socializador e os socializados.

\section{c) Seqüenciais e Não Seqüenciais}

A socialização seqüencial caracteriza-se por processos transitórios marcados por uma série de etapas identificáveis, abordadas dentro de uma progressão, por meio das quais um indivíduo passa a ocupar uma posição e a exercer determinado papel dentro da organização.

As técnicas não seqüenciais são realizadas provisoriamente e independem das relações com outras etapas anteriormente realizadas. Logo, é vantajoso para determinadas organizações que haja um programa seqüencial que facilite a aprendizagem, pois os programas não seqüenciais podem não ficar claros e trazer dificuldade ao processo de socialização.

\section{d) Fixas e Variáveis}

As estratégias de socialização fixas proporcionam a um novo membro um conhecimento necessário para completar determinado estágio e, desse modo, o tempo de mudança é padronizado, possuindo início e fim determinados. Nas estratégias de socialização variáveis, o tempo não é padronizado, essa estratégia não tem início nem fim previamente demarcados, pois depende do desenvolvimento apresentado pelo novo membro no processo de integração (logo, os indivíduos não conhecem a duração do período de mudanças). 


\section{e) Por Competição ou Por Concurso}

As estratégias de socialização por competição caracterizam-se pela distribuição dos novos membros em grupos ou diferentes programas de socialização, de acordo com as habilidades e ambições de cada. Em contrapartida, as estratégias por concurso permitem uma participação e uma cooperação maior entre os indivíduos que pertencem ao mesmo grupo de avaliação.

Em situações de competição, cada pessoa age por conta própria e raramente vai querer se unir a um grupo para agir contra ou a favor da organização, pois esta estratégia é aplicada de maneira que o indivíduo passa para um nível mais alto na organização e aqueles que deixam de concluí-la são descartados do processo da empresa. As estratégias de concurso, em contrapartida, produzem um espírito cooperativo e participativo entre as pessoas da organização.

\section{f) Seriais e Disjuntivas de Socialização}

Para Van Maanen (1978), classifica-se o processo de socialização como serial quando os membros mais experientes preparam os recém-chegados para assumir suas funções antigas na organização. Já Para Fogarty (2000), a estratégia passa a ser serial quando o papel que o supervisor direto antes detinha é agora desempenhado pelo entrante. Assim, se a empresa preza pela continuidade dos processos, a estratégia serial é a ideal (VAN MAANEN, 1978). Por outro lado, se não há alguém disponível para mostrar o caminho a ser seguido pelo entrante, o processo de socialização classifica-se como disjuntivo (VAN MAANEN, 1978).

Vale ressaltar que, algumas vezes, um processo aparentemente serial pode ser na verdade classificado como disjuntivo quando, por exemplo, a área de recursos humanos cuida sozinha de todos os aspectos do treinamento (VAN MAANEN, 1978).

\section{g) Investidura e Despojamento}

Estas estratégias objetivam aprovar ou adaptar a identidade do novato na organização. Na estratégia por meio da investidura, a organização busca confirmar o perfil do novo membro, quando este é viável para seus interesses. Já na 
estratégia de despojamento, procura adaptar o perfil do novo membro aos interesses da organização, fazendo com que os novos membros passem por vários testes rigorosos para obter acesso às posições na estrutura da organização.

Van Maanen (1996, p. 59) ressalta que "as estratégias de despojamento, no lugar das estratégias de investiduras, provavelmente produzem resultados similares entre os novatos".

Deve-se destacar que o autor entende que há uma gama de possibilidades de controle sobre o comportamento do indivíduo nas organizações, e que estas dependem diretamente dos modos como a organização socializa a pessoa. Por esta razão, é muito importante que a organização escolha e adote corretamente as estratégias de socialização.

Tais estratégias, ao serem adotadas, de forma consciente e planejada por aqueles que as gerenciam, tendem a estruturar as experiências de aprendizagem dos indivíduos, aumentando as chances de obtenção das respostas esperadas.

Van Maanen (1996) acrescenta ainda que certas estratégias tendem a encorajar nos indivíduos comportamentos mais conformistas (o indivíduo se ajusta ao novo papel sem questioná-lo ou sem provocar nele mudanças significativas), enquanto outras tendem a favorecer comportamentos inovadores (o indivíduo altera o modo como o papel é tradicionalmente desempenhado na organização). Isso significa que uma organização, antes de iniciar o processo de socialização, deve definir com clareza o resultado esperado, para que possa combinar corretamente as estratégias disponíveis. 
3.

\section{Metodologia da Pesquisa}

Nesta seção, serão apresentados: o tipo de pesquisa, a estratégia de investigação, a seleção das entrevistas, as técnicas para coleta, análise e tabulação de dados e as limitações do método.

\section{1.}

\section{Tipo da Pesquisa}

Foi feita uma revisão preliminar da literatura para delinear o objeto do estudo e, posteriormente, balizar a pesquisa de campo e a análise dos resultados. A metodologia utilizada nesta pesquisa de campo, quanto à forma de abordagem do problema, foi a qualitativa, fundamentada $\mathrm{em}$ entrevistas individuais realizadas, por meio de questões semi-estruturadas e que foram gravadas, transcritas e analisadas.

Com base na metodologia utilizada por Gil (2002) que define pesquisa descritiva como aquela que tem foco principal na descrição das características de determinada população ou fenômeno, podemos inferir que, quanto aos fins de investigação, que se trata de uma pesquisa descritiva do ponto de vista dos objetivos já que busca descrever as percepções dos recém-chegados sobre a Ambientação, o Curso de Formação e os valores organizacionais preconizados pela Empresa. Além disso, também pode ser classificada como exploratória, pois há pouco conhecimento acumulado e sistematizado sobre a influência das práticas de socialização na transferência dos valores organizacionais aos empregados recém-chegados.

Nessa mesma linha e, quanto aos meios de investigação, trata-se uma pesquisa de campo, com caráter documental. Pesquisa de campo porque representa uma investigação empírica no local onde ocorre o fenômeno, ou seja, na própria organização. E documental por abranger materiais que não receberam ainda tratamento analítico. 


\section{2.}

\section{Estratégia de investigação}

Por concentrar-se na investigação de uma única organização, circunscrita às pessoas entrevistadas, ter caráter de profundidade e detalhamento, optou-se por fazer um estudo de caso, em uma sociedade de economia mista da administração indireta, pertencente ao ramo de energia.

De acordo com Stake (apud CRESWELL, 2007), no estudo de caso, o pesquisador explora em profundidade uma atividade, processo ou uma ou mais pessoas. Além disso, o pesquisador se utiliza de diversos procedimentos para a coleta dos dados como entrevistas, formulários, questionários etc.

\section{3.}

\section{Seleção dos Entrevistados}

A pesquisa teve por objetivo analisar se os valores discursados pela Companhia foram internalizados pelos empregados. As entrevistas foram realizadas com os empregados que entraram na Companhia no ano de 2006, candidatos ao Cargo de Administrador Junior, e participaram juntos do Programa de Formação de Empregados por aproximadamente 5 meses antes de assumirem suas funções na empresa.

O critério utilizado para a seleção dos respondentes foi o fato de terem participado de uma mesma turma, no mesmo período e de terem compartilhado experiências comuns durante a Ambientação e o Curso de Formação.

A partir das entrevistas, foi possível identificar semelhanças e incoerências entre o Discurso e a Prática da Companhia com base nas percepções de cada entrevistado

Ainda com relação à seleção dos indivíduos, buscou-se uma variedade de perfis que refletisse o conjunto de empregados que participaram do programa, em termos de variáveis como sexo, idade, tempo de experiência no mercado de trabalho e tipos de empresas nas quais haviam predominantemente trabalhado antes de ingressarem no programa. No entanto, os perfis disponíveis mostraram-se menos diferenciáveis, dado que se tratava de um grupo que possuía um grau 
relativamente elevado de homogeneidade. Vale ainda esclarecer que a pesquisadora, que também foi uma integrante dessa turma, já possuía relação de familiaridade com os indivíduos entrevistados.

De uma turma de 60 alunos, foram entrevistados 16 indivíduos de ambos os sexos, diferentes idades e experiências anteriores de trabalho diversas. $\mathrm{O}$ quadro a seguir apresenta as principais informações acerca dos entrevistados:

Quadro 1 - Perfil dos Respondentes

\begin{tabular}{|c|c|c|c|c|c|}
\hline Entrevistado & Gênero & Idade & Cargo/Função & Área & Experiência Anterior \\
\hline 1 & Feminino & 32 & Administradora Plena & \begin{tabular}{|l|} 
Relações Institucionais - \\
Recursos Humanos \\
\end{tabular} & $\begin{array}{l}\text { Trabalhou em uma imobiliária no Setor de } \\
\text { Condomínios. }\end{array}$ \\
\hline 2 & Masculino & 34 & Administrador Pleno & $\begin{array}{l}\text { Planejamento e Avaliação - } \\
\text { Recursos Humanos }\end{array}$ & $\begin{array}{l}\text { Trabalhou como Caixa do BANERJ e como vendedor } \\
\text { de produtos na Caixa Econômica - atendimento ao } \\
\text { público em geral. }\end{array}$ \\
\hline 3 & Masculino & 31 & Administrador Pleno & $\begin{array}{l}\text { Planejamento e Avaliação - } \\
\text { Recursos Humanos }\end{array}$ & $\begin{array}{l}\text { Trabalhou como administrador em uma empresa de } \\
\text { meio ambiente na parte administrativa-financeira, } \\
\text { trabalhou também na AMBEV e na área financeira da } \\
\text { Refinaria de João Pessoa. }\end{array}$ \\
\hline 4 & Masculino & 31 & Administrador Pleno & $\begin{array}{l}\text { Planejamento e Gestão - } \\
\text { AMS - Recursos Humanos }\end{array}$ & $\begin{array}{l}\text { Trabalhou como administrador em um escritório de } \\
\text { advocacia e, depois, como analista financeiro da } \\
\text { UNIFACS. }\end{array}$ \\
\hline 5 & Masculino & 33 & Administrador Pleno & $\begin{array}{l}\text { Organização e Gestão - } \\
\text { Gestão Corporativa - } \\
\text { Abastecimento Corporativo }\end{array}$ & $\begin{array}{l}\text { Trabalhou como estagiário na Vale do Rio Doce, } \\
\text { depois como terceirizado em pesquisa acadêmica e na } \\
\text { parte administrativa no IPEA. }\end{array}$ \\
\hline 6 & Feminino & 40 & Administradora Plena & $\begin{array}{l}\text { Contratação de Serviços } \\
\text { Tecnológicos - Gestão } \\
\text { Tecnológica } \\
\end{array}$ & $\begin{array}{l}\text { Foi empresária de uma loja de brinquedos e } \\
\text { utilidades, trabalhou } 1 \text { ano na Telemar e, depois, } \\
\text { como Analista de Vendas na Casa da Moeda }\end{array}$ \\
\hline 7 & Feminino & 36 & Administradora Plena & $\begin{array}{l}\text { Contratação de Serviços } \\
\text { Tecnológicos - Gestão } \\
\text { Tecnológica } \\
\end{array}$ & $\begin{array}{l}\text { Trabalhou nos Correios - cargo de de nível médio por } \\
7 \text { anos }\end{array}$ \\
\hline 8 & Masculino & 34 & Administrador Pleno & $\begin{array}{l}\text { Administração de Serviços - } \\
\text { Regional Sudeste - Serviços } \\
\text { Compartilhados }\end{array}$ & $\begin{array}{l}\text { Trabalhou como Auxiliar Administrativo na BR por } 8 \\
\text { anos. }\end{array}$ \\
\hline 9 & Feminino & 39 & Administradora Plena & \begin{tabular}{|l|} 
Desenvolvimento de \\
Recursos Humanos - \\
Unidade de Operação de \\
Exploração e Produção do \\
Rio de Janeiro - UO- \\
RIO/RH/DRH \\
\end{tabular} & $\begin{array}{l}\text { Trabalhou em uma multinacional de cerveja e } \\
\text { refrigerante por } 7 \text { anos, depois em uma empresa do } \\
\text { ramo de petróleo por } 5 \text { anos. }\end{array}$ \\
\hline 10 & Feminino & 41 & Coordenadora & $\begin{array}{l}\text { Implantação do COMPERJ - } \\
\text { Abastecimento Programas de } \\
\text { Investimento }\end{array}$ & $\begin{array}{l}\text { Trabalhou na Caixa Econômica como Administradora. } \\
\text { Tinha uma empresa de consultoria e ministrava aulas } \\
\text { pelo SEBRAE. }\end{array}$ \\
\hline 11 & Feminino & 31 & Coordenadora & $\begin{array}{l}\text { Administração e Carreira - } \\
\text { Pbio }\end{array}$ & Trabalhou como Gerente de Contas no Unibanco. \\
\hline 12 & Masculino & 31 & Coordenador & Organização e Gestão - Pbio & Trabalhou na área de logística na Nestlé. \\
\hline 13 & Feminino & 29 & Coordenadora & $\begin{array}{l}\text { Organização e Gestão - } \\
\text { Gestão Corporativa - } \\
\text { Abastecimento Corporativo }\end{array}$ & $\begin{array}{l}\text { Trabalhou com Técnica Administrativa na Agência } \\
\text { Nacional de Saúde. }\end{array}$ \\
\hline 14 & Feminino & 32 & Administradora Plena & $\begin{array}{l}\text { Contratação de Serviços - } \\
\text { Suporte Operacional - } \\
\text { Refinaria Gabriel Passos }\end{array}$ & Trabalhou no Banco do Brasil - cargo de nível médio. \\
\hline 15 & Feminino & 30 & Coordenadora & Apoio à Gestão - Engenharia & $\begin{array}{l}\text { Fez estágio em uma assessoria de imprensa e } \\
\text { trabalhou um ano e meio na IBM em uma área de } \\
\text { auditoria e faturamento. }\end{array}$ \\
\hline 16 & Feminino & 31 & Gerente & $\begin{array}{l}\text { Planejamento e Gestão do } \\
\text { E\&P - Construção de Sondas }\end{array}$ & $\begin{array}{l}\text { Trabalhou na área de logística em uma empresa de } \\
\text { Petroquímica. }\end{array}$ \\
\hline
\end{tabular}

Fonte: Autoria própria, (2012). 


\section{4.}

\section{Coleta dos Dados}

Para a coleta de dados, foram utilizados dados primários e secundários. Com relação aos dados secundários, foram utilizados: documentos da Empresa (relatórios, manuais e normas), além de artigos, teses, sites e livros relacionados ao tema. Já com relação às fontes primárias, a coleta de dados de campo ocorreu por meio de entrevistas realizadas com 16 indivíduos que participaram do Programa de Formação de Empregados, no ano de 2006, candidatos à época ao cargo de Administrador.

As entrevistas tiveram duração entre 30 e 60 minutos, foram realizadas durante os meses de junho e julho de 2012, e ocorreram em local reservado no próprio ambiente de trabalho dos entrevistados. As entrevistas foram direcionadas por meio de questionários abertos e semi-estruturados e foram gravadas em áudio e transcritas na íntegra quanto ao seu conteúdo

Foram eliminadas informações que pudessem identificar os indivíduos entrevistados e outras pessoas citadas durante as entrevistas. As transcrições também foram editadas para corrigir erros de português e vícios de linguagem. Entretanto, em todas as modificações, houve o cuidado em manter a intenção do entrevistado e em não alterar o seu conteúdo.

Vale destacar que, para Flick (2009), o objetivo da entrevista com questionário semi-estruturado é revelar o conhecimento do entrevistado, expressando-o na forma de respostas. Esse tipo de entrevista permite ao pesquisador confrontar as pressuposições com a percepção do entrevistado.

\section{5.}

\section{Tabulação e Análise dos Dados}

Uma questão primordial na análise qualitativa é a identificação dos temas principais os quais merecerão maior tempo de análise. Dessa forma, nesta pesquisa, os temas foram sendo destacados durante todo processo, isto é, iniciando-se antes da coleta das informações e continuando até após as entrevistas. 
A partir da identificação dos temas principais, foram criadas categorias tanto a partir do referencial teórico quanto da necessidade da pesquisa. Essa codificação foi possível com a utilização de tabelas no software Excel. Para aglutinar os temas e suas respectivas categorias, foram criadas quatro etapas de análise:

- Etapa 1 - Análise do período Anterior à Entrada Organizacional Categorias: expectativas para se inscrever no processo seletivo público, imagem da empresa e contra-partida do empregado.

- Etapa 2 - Análise da Ambientação e do Curso de Formação (5 meses aproximadamente). Categorias: Ambientação como lavagem cerebral, oportunidade para conhecer a empresa e mundo ideal; Orgulho da Empresa como resultado da Ambientação; Ambientação e Curso de Formação como Rede de Contatos; Curso de Formação: validade, formato e aproveitamento; Principais pontos destacados sobre o conteúdo das palestras durante a Ambientação; Qualidade de Vida e Preocupação com o Empregado; Segurança da Informação, Espionagem Industrial; Perfil do Empregado Padrão Empresa X.

- Etapa 3 - Análise do período entre a Alocação de fato na Área até a data da entrevista. Categorias: $O$ que te segura até hoje na Companhia; Identificação com os Valores e Comportamentos; Comparação entre o discurso e a prática.

- Etapa 4 - Avaliação da Percepção do Empregado sobre o seu Processo de Socialização a luz das teorias de Van Maanen.

Cabe mencionar que o processo de análise é fundamental para que todos os dados obtidos nas entrevistas possam ser revertidos em conclusões úteis para os agentes que tenham interesse em aprender com o tema.

\section{6.}

\section{Limitações do Método}


Um primeiro aspecto se refere à homogeneidade do grupo de entrevistados no que se refere à formação acadêmica, o que pode ter determinado alguma similaridade quanto à tendência das respostas. Além disso, a idade dos candidatos era relativamente próxima, com uma diferença máxima de doze anos, o que os deixa muito próximos no que tange à experiência no mercado de trabalho, podendo gerar convergências de opiniões.

Por se tratar de método qualitativo, a análise interpretativa de conteúdo das entrevistas pode ter sido influenciada pela própria percepção da pesquisadora, já que a mesma participou do Curso de Formação juntamente com os entrevistados. Além disso, no intuito de comprovar suas próprias percepções iniciais, a pesquisadora pode ter influenciado na abordagem do tema.

Outro aspecto limitador é a quantidade de entrevistas que não pode ser considerada como representativa de todas as pessoas que ingressam no setor público. Vale lembrar ainda que a questão do tempo e dos recursos inviabilizou a realização de um número superior de entrevistas dentro da mesma turma de formandos, ou mesmo na escolha de alguma outra carreira para que fosse possível comparar as percepções de acordo com o nível de formação.

Por último, há que se considerar que a Ambientação e o Curso de Formação ocorreram há mais de seis anos, o que não garante que as informações passadas pelos entrevistados reflitam exatamente suas percepções e vivências da época. 


\section{4.}

\section{Descrição do Caso}

\section{1.}

\section{Características Gerais}

A Empresa X é uma sociedade anônima de capital aberto, cujo acionista majoritário é o Governo do Brasil, e atua como uma empresa de energia nos seguintes setores: exploração e produção, refino, comercialização e transporte de óleo e gás natural, petroquímica, distribuição de derivados, energia elétrica, bicombustíveis e outras fontes renováveis de energia.

Como líder do setor petrolífero brasileiro, expandiu suas operações para estar entre as cinco maiores empresas integradas de energia no mundo até 2020. Hoje, está presente em 28 países. O Plano de Negócios 2010-2014 prevê investimentos de US\$224 bilhões.

\section{2.}

\section{História da Empresa $\mathrm{X}$}

A Empresa X foi fundada no dia 3 de outubro de 1953 pelo presidente Getúlio Vargas, com o objetivo de executar as atividades do setor petrolífero no Brasil em nome da União. A criação da Empresa $X$ foi resultado da campanha popular que começou em 1946, com o histórico slogan "O petróleo é nosso".

Apesar de ter sido criada em 1953, sua instalação só foi concluída em 54, ao herdar do Conselho Nacional de Petróleo duas refinarias, a de Mataripe (BA) e a de Cubatão (SP). Elas passaram a ser os primeiros ativos (patrimônio) da empresa. Em 10 de maio de 54, a empresa começa a operar, com uma produção de 2.663 barris, equivalente a $1,7 \%$ do consumo nacional. Nesse mesmo ano, o petróleo e seus derivados já representavam $54 \%$ do consumo de energia no país.

Em 1961, é fundada a REDUC - Refinaria Duque de Caxias - hoje a mais completa refinaria do Sistema. Foi a primeira a ser construída pela empresa tendo em vista que as outras foram incorporadas. 
Ela tem aproximadamente $13 \mathrm{~km} 2$ e é responsável por cerca de 1,2 bilhões de reais por ano em impostos pagos ao governo. Produz óleos básicos para lubrificantes, diesel, gasolina, GLP, nafta, querosene de aviação, parafinas, óleo combustível, aguarrás e outros.

Ainda em 61, a gigante lança-se ao mar, dando início à procura de petróleo na plataforma continental, em uma faixa que vai do Espírito Santo ao Maranhão (plataforma continental é a porção dos fundos marinho pouco profunda - até $200 \mathrm{~m}$ ). Nesse mesmo ano, foi inaugurado o primeiro posto de abastecimento da Empresa X, em Brasília, e a empresa atingiu um de seus principais objetivos: a auto-suficiência na produção dos principais derivados, graças ao início do funcionamento da REDUC.

Em 1967, é constituída a subsidiária Empresa X Química S.A (Petroquisa) para articular a ação dos setores: estatal e privado na implantação da indústria petroquímica no país. A implantação de uma indústria transformadora de nafta em eteno, vislumbrada tanto por empresários do setor de refino de petróleo quanto pelo governo, marca o início da história do setor petroquímico brasileiro.

Já em 1968, é criado o Cenpes, com o objetivo de atender às demandas tecnológicas, que são base para a consolidação e expansão da Empresa X no cenário da energia mundial. Após receber os maiores prêmios do setor petrolífero mundial, o Cenpes consolidou-se como o maior centro de pesquisas da América Latina. Além disso, as tecnologias desenvolvidas no Cenpes fazem da Empresa X a empresa que mais gera patentes no Brasil e no exterior.

Também em 1968, a primeira descoberta de petróleo no mar foi em Sergipe, no Campo de Guaricema, a 80 metros de profundidade, comprovando a existência de petróleo na plataforma continental. Deu-se inicio à tradição de batizar com nomes de animais aquáticos as descobertas em alto-mar. Nesse mesmo ano, entra em operação a primeira plataforma de perfuração de petróleo construída no Brasil (nomeada como P-1). Em uma época de petróleo importado a baixo custo - cerca de US\$ 3 por barril - investir no desenvolvimento de Guaricema foi uma decisão estratégica da Empresa X: era necessário que os técnicos brasileiros aprendessem a trabalhar no mar.

Com a missão de contribuir para o desenvolvimento do país, comercializando, distribuindo e industrializando derivados de petróleo e outros 
produtos, em 1971, a Empresa $X$ cria então a subsidiária Empresa $X$ Distribuidora. A empresa era responsável por $21 \%$ do mercado. Em 1975, tornouse líder no segmento de distribuição de derivados de petróleo - posição que nunca mais perdeu.

No início dos anos 70, os membros da Organização dos Países Produtores de Petróleo (OPEP) elevaram substancialmente os preços internacionais, provocando o chamado Choque do Petróleo. Com isso, o mercado tornou-se conturbado e marcado por incertezas, não apenas quanto aos preços, como também quanto à garantia do suprimento. Como importante cliente das companhias estatais dos países da OPEP, com as quais manteve bom relacionamento ao longo dos anos, a Empresa $\mathrm{X}$ conseguiu manter o abastecimento do mercado brasileiro.

Para superar as dificuldades, o governo adotou medidas econômicas, algumas diretamente ligadas às atividades da Empresa $\mathrm{X}$, como a redução do consumo de derivados e o aumento da oferta interna de petróleo. Passou a ser dada prioridade aos investimentos em exploração no mar e produção, ocasionando aumento da produção do petróleo nacional que, por sua vez, passou a ocupar espaço cada vez maior na carga das refinarias.

Nesse momento de crise, no qual o preço do petróleo estava alto, a melhor alternativa foi continuar investindo na exploração do mar. Ao aumentar a produção nacional, o Brasil dependeria menos de importar um produto caríssimo, conseguindo também aumentar as reservas, o que tornaria possível aumentar suas exportações.

Em 1974, foi descoberta a Bacia de Campos - situada na costa norte do estado do Rio de Janeiro, estendendo-se até o sul de Espírito Santo, com aproximadamente 100 mil quilômetros quadrados. Ela se torna maior província petrolífera do Brasil, responsável por mais de $80 \%$ da produção nacional do petróleo. Perfurado pela $1^{\text {a }}$ vez em 1976, a uma lâmina d'água de 100 metros.

A exploração comercial iniciou em 1977, com o campo de Enchova, com uma produção de 10 mil barris por dia em uma plataforma flutuante.

Nos anos seguintes, sucessivas descobertas deslocaram as atenções e os investimentos para a Bacia de Campos. Após a descoberta do Campo de Garoupa, a Empresa X ainda descobriria, no ano seguinte, os campos de Pargo, Namorado e Badejo e, em 1977, os campos de Bonito, Cherne e Pampo. 
Em novembro de 1984, o campo de Albacoara foi descoberto na Bacia de Campos, provando a existência de campos gigantes a grandes profundidades no Brasil, marcando a história da empresa em exploração em águas profundas, nunca antes exploradas.

O campo de Marlim foi descoberto em janeiro de 1985. Está localizado na Bacia de Campos, distante aproximadamente $110 \mathrm{~km}$ do litoral do Rio de Janeiro. Nesse ano, o país já produzia metade do petróleo que consumia, muito acima dos 14\% registrados em 1979. Ainda que situado em lâminas de água jamais exploradas, apontava, pelo volume de reservas, para a auto-suficiência e para novos horizontes exploratórios em toda a plataforma continental.

Entrava, em 1986, em operação o Campo de Urucu, situado na Bacia do Rio Solimões. Um marco histórico das atividades da Empresa $X$ na região. $A$ descoberta respondeu a uma antiga indagação, mostrando, afinal, que havia petróleo comercial, de excelente qualidade, e associado ao gás, na Amazônia.

Em 1988, entra em produção o campo de Rio Urucu, no Alto Amazonas, descoberto dois anos antes. A Empresa X se antecipa à lei e retira totalmente o chumbo tetraetila da gasolina.

Em 1986, foi criado o Procap - Programa de Capacitação Tecnológica em Águas Profundas. Era um projeto extremamente ambicioso, pois, na época, a Empresa X explorava petróleo na faixa dos 150 metros e já tinha planos para os 1000 metros. Foi um sucesso e a empresa é, atualmente, líder mundial na área.

O monopólio estatal do petróleo termina por meio da Emenda Constitucional $\mathrm{n}^{\circ}$ 9, de 9.11.1997. A Companhia se torna uma das maiores empresas de petróleo do mundo.

Para ajudar o Brasil a vencer a crise do "apagão energético", a Empresa X compra participações em diversas termelétricas que transformam o gás em energia elétrica em 2000. É uma estratégia eficiente para diversificação e ampliação da matriz energética brasileira. A termelétrica da Fábrica de Fertilizantes Nitrogenados (Fafen), na Bahia, é a primeira usina com participação da Empresa $\mathrm{X}$ a entrar em operação.

Em 2003, nos 50 anos de Empresa X, a produção de petróleo no Brasil e no exterior supera a marca de dois milhões de barris diários e, em 2004, é inaugurada 
a $1^{\text {a }}$ usina eólica da Empresa $\mathrm{X}$, em escala piloto, na cidade de Macau, no Rio Grande do Norte.

Em 2005, Empresa X bate o recorde brasileiro de profundidade de perfuração, com um poço inclinado que chegou a 6.915 metros além do fundo do mar. O poço foi perfurado na bacia de Santos, localizado a $200 \mathrm{~km}$ da costa sul da cidade do Rio de Janeiro. E, em 2006, alcança a auto-suficiência, com a entrada em operação das plataformas p-34 e p-50 e produção média diária de 1,9 milhões de barris por dia, o país passou a exportar mais petróleo e derivados do que importar.

Em conjunto com o Grupo Ultra e o BNDES, foi desenvolvido um estudo para implantação do Complexo Petroquímico, no município de Itaboraí, no Rio de Janeiro em 2007. O Comperj tem como principal objetivo aumentar a produção nacional de produtos petroquímicos, com o processamento de cerca de $150 \mathrm{mil}$ barris/dia de óleo pesado nacional.

Uma nova era de energia surgia quando, em 2007, foi anunciada a descoberta da área de Tupi, na Bacia de Santos, com grande concentração de petróleo e gás em seções de pré-sal, com quantidade de petróleo tão significativa que colocaria a Empresa X e o Brasil em um novo cenário da indústria mundial do setor.

Em 2008, é criada a empresa Empresa X Biocombustível, subsidiária responsável pelo desenvolvimento de projetos de produção e gestão de etanol e biodiesel.

Em $1^{\circ}$ de maio de 2009, tem início a produção de petróleo na área de Tupi. As jazidas do pré-sal podem mudar o perfil das reservas da Companhia, que, em sua maior parte, é de petróleo pesado, reduzindo a importação de óleo leve e gás natural.

\section{3.}

\section{Missão, Visão, Valores e Comportamentos Organizacionais}

A Missão da Empresa X para 2020 é atuar de forma segura e rentável, com responsabilidade social e ambiental, nos mercados: nacional e internacional, 
fornecendo produtos e serviços adequados às necessidades dos clientes e contribuindo para o desenvolvimento do Brasil e dos países onde atua.

Sua Visão 2020 é ser uma das cinco maiores empresas integradas de energia do mundo, e a preferida pelos públicos de interesse. Com base nos atributos da Visão para 2020, a atuação da Companhia se destacará por: Forte Presença internacional; Referência mundial em biocombustíveis; Excelência operacional, em gestão, recursos humanos e tecnologia; Rentabilidade; Referência em responsabilidade social e ambiental e Comprometimento com o desenvolvimento sustentável.

Seus valores estão descritos no Plano Estratégico, e são a forma como a Companhia pauta suas estratégias, ações e projetos. Devem estar presentes na condução das atividades e refletir o jeito de ser da Empresa X. Entre eles, citamse:

- Desenvolvimento Sustentável: Perseguimos o sucesso dos negócios com uma perspectiva de longo prazo, contribuindo para o desenvolvimento econômico e social e para um meio ambiente saudável nas comunidades onde atuamos

- Integração: Buscamos maximizar a colaboração e a captura de sinergias entre equipes, áreas e unidades, assegurando a visão integrada da companhia em nossas ações e decisões

- Resultados: Buscamos incessantemente a geração de valor para as partes interessadas, com foco em disciplina de capital e gestão de custos. Valorizamos e reconhecemos, de forma diferenciada, pessoas e equipes com alto desempenho

- Prontidão para mudanças: Estamos prontos para mudanças e aceitamos a responsabilidade de inspirar e criar mudanças positivas

- Empreendedorismo e inovação: Cultivamos a superação de desafios e buscamos incessantemente a geração e implementação de soluções tecnológicas e de negócios inovadoras que contribuam para o alcance dos objetivos estratégicos da Empresa X

- Ética e transparência: Nossos negócios, ações, compromissos e demais relações são orientados pelos Princípios Éticos do Sistema Empresa X. 
- Respeito à vida: Respeitamos a vida em todas as suas formas, manifestações e situações e buscamos a excelência nas questões de saúde, segurança e meio ambiente

- Diversidade humana e cultural: Valorizamos a diversidade humana e cultural nas relações com pessoas e instituições. Garantimos os princípios do respeito às diferenças, da não discriminação e da igualdade de oportunidades.

- Pessoas: Fazemos das pessoas e de seu desenvolvimento um diferencial de desempenho da Empresa X

- Orgulho de ser Empresa X: Nós nos orgulhamos de pertencer a uma empresa brasileira que faz a diferença onde quer que atue, por sua história, suas conquistas e por sua capacidade de vencer desafios

\section{Comportamentos:}

- Ética nos negócios;

- Liderança pelo exemplo;

- Ênfase na integração e no desenvolvimento no trabalho de equipe;

- Foco no desenvolvimento e na sustentação de vantagens competitivas;

- Acompanhamento rigoroso dos resultados, com reconhecimento e responsabilização pelo desempenho;

- Transparência nas relações com acionistas, empregados, comunidades e com os demais públicos de interesse da Empresa X.

\section{4.}

\section{Objetivos Estratégicos de Recursos Humanos}

A partir do desdobramento do Plano de Negócios, a área de Recursos Humanos coordena e executa, em nível estratégico, ações de recursos humanos de interesse corporativo, tendo como objetivos estratégicos:

- Assegurar que a Empresa disponha das competências necessárias às suas estratégias; 
- Promover o comprometimento e a satisfação dos empregados, fortalecendo sua identificação com os valores da Empresa.

\section{5.}

\section{Sobre a Universidade Corporativa Empresa X}

A preparação de brasileiros para a indústria petrolífera começou antes da criação da Empresa X e quando ainda existia o Conselho Nacional do Petróleo CNP. Em 1938, época de criação do CNP, o conhecimento era todo importado mediante a contratação de técnicos estrangeiros. Logo após a comprovação da existência de petróleo em solo brasileiro, em Lobato-BA, em 1939, o CNP enviou os primeiros técnicos brasileiros para treinamento especializado nos Estados Unidos. Alguns desses pioneiros iniciaram também a implantação dos primeiros cursos de petróleo no Brasil, por meio de convênios com a Universidade Federal da Bahia - UFBA e a Universidade do Brasil (atual Universidade Federal do Rio de Janeiro - UFRJ).

Em 1952, o CNP criou o Setor de Supervisão de Aperfeiçoamento Técnico com a finalidade específica de formar recursos humanos para dotar o país de técnicos necessários à exploração e produção.

Com a criação da Empresa X, deu-se continuidade ao esforço de formação da mão de obra brasileira para a indústria de petróleo, buscando-se, assim, o processo de desenvolvimento das competências necessárias para o sucesso da Companhia e, desde o início de suas atividades, vem investindo fortemente na formação de seus profissionais. Esses profissionais, por diversas vezes, eram enviados ao exterior para realização de cursos de especialização ou outras vezes participavam de cursos internos ou conveniados com instituições de ensino no Brasil.

Em 1955, a Empresa X criou o Centro de Aperfeiçoamento de Pesquisas de Petróleo (CENAP), órgão responsável pela formação e pelo desenvolvimento dos recursos humanos e também pelas pesquisas em exploração e produção de petróleo.

Em 1966, o CENAP foi desmembrado. As atividades de ensino e aperfeiçoamento passaram para o Serviço de Pessoal (SEPES) enquanto que as 
atividades de pesquisa ficaram a cargo do Centro de Pesquisas e Desenvolvimento.

O SEPES passou a atuar em Treinamento e Desenvolvimento por intermédio da Divisão de Ensino e dos dois Centros de Treinamento a ela subordinados, um da Bahia e outro no Rio de Janeiro. O Centro de Treinamento da Bahia sempre teve a atuação mais voltada para a área de Exploração e Produção, com cursos de formação e reciclagem no segmento da Engenharia de Petróleo. Já o núcleo do Rio de Janeiro era mais dedicado prioritariamente às áreas de Refino, Equipamentos e Informática.

Com a reestruturação da Companhia, em 2000, os dois Centros e mais a Divisão de Desenvolvimento de Recursos Humanos, do então Serviço de Recursos Humanos, deram origem à Universidade Corporativa Empresa X.

Hoje, a Universidade Corporativa Empresa X continua com o enorme desafio de contribuir para que a Companhia mantenha suas competências e adquira outras necessárias para transformá-la em uma empresa integrada de energia.

\subsection{1.}

\section{O Programa de Formação de Empregados}

O processo de capacitação técnica de seu corpo de empregados, desenvolvido ao longo dos anos, contribuiu para que a Empresa $\mathrm{X}$ obtivesse um corpo técnico de alto nível.

A partir de 2000, além da formação dos empregados, começou-se a avaliar a necessidade de se introduzir a preocupação com a transmissão de valores e comportamentos definidos no Planejamento Estratégico da Companhia.

Sendo assim, os candidatos, quando admitidos ou readmitidos nos cargos Juniores, participam de Programa de Formação de Empregados, realizado após a admissão ou readmissão, conforme normas internas. Os participantes do Programa de Formação de Empregados são submetidos a regime de dedicação integral, sendo obrigatória a freqüência às aulas e às demais atividades descritas no plano de desenvolvimento do curso. 
A admissão ou a readmissão do candidato, como empregado da Empresa $\mathrm{X}$ para participar do Programa de Formação de Empregados, é obrigatoriamente precedida da assinatura do Termo de Compromisso e Responsabilidade com a Empresa X, o qual prevê o ressarcimento dos custos, no caso de pedidos de demissão por interesse do empregado durante o curso ou até dois anos após a sua conclusão. São excluídos do Programa de Formação de Empregados e desligados da Companhia aqueles empregados que não obtêm as notas definidas no plano de desenvolvimento do curso ou infringirem as normas da Empresa X.

O participante admitido e aprovado em processo seletivo público que for desligado do Programa de Formação de Empregados, qualquer que seja o motivo, terá, conseqüentemente, seu Contrato Individual de Trabalho rescindido, aplicando-se, em cada caso, o disposto na Consolidação das Leis do Trabalho (CLT).

\subsubsection{1.}

\section{Conceituação}

Segundo Regimento Interno, o Programa de Formação é de caráter obrigatório e eliminatório, tendo como objetivo complementar os conhecimentos dos novos empregados ou aqueles em mudança de cargo, indispensáveis à sua atuação profissional, de acordo com as necessidades e demandas específicas das áreas e unidades de negócio da Companhia.

Com base nas normas de RH, tem-se que o Programa:

- É composto por várias disciplinas, de acordo com o Plano de desenvolvimento do Curso, ministrado normalmente para empregados recém-admitidos na Companhia ou em mudança de cargo, para capacitálos a assumir e desempenhar atividades descritas nos cargos profissionais da Empresa X.

- Destina-se aos egressos de processo seletivo, para provimento de cargos no primeiro nível nas carreiras de nível médio e superior, e para a reclassificação dos profissionais de nível médio, visando à capacitação e avaliação profissional dos participantes no desempenho de atribuições na 
Companhia, por meio da complementação da formação acadêmica e profissional.

Com relação às diretrizes gerais do Programa, o Comitê Executivo de Recursos Humanos aprovou o seguinte:

- Alinhar o Programa de Formação ao Plano Estratégico da Companhia;

- Adequar a duração dos Cursos de Formação às necessidades da Empresa;

- Assegurar que, quando o conteúdo atual tiver característica de educação continuada, o Curso de Formação deve ser eliminado, restringindo-se à Ambientação;

- Assegurar que todos os Cursos de Formação abordem o tema gestão de SMS, Segurança da Informação e Responsabilidade Social;

- Tornar a Dimensão Institucional obrigatória para todos os profissionais admitidos pela Companhia, independentemente da existência ou não de Curso de Formação.

\subsubsection{2.}

\section{Fases do Programa de Formação de Empregados}

Para melhor entendimento do Programa, o Macro-Processo de Programa de Formação de Empregados apresenta as seguintes fases:

\section{a) Sobre a Dimensão Institucional (Ambientação)}

Entre as diversas etapas do Programa de Formação, destaca-se a Dimensão Institucional ou Ambientação, logo após a realização de processo seletivo público. Nessa fase, os recém-admitidos têm o seu primeiro contato com a Cultura e com os Valores Empresa X.

A Ambientação se realiza em uma ou duas semanas de palestras: período em que o empregado assina o contrato de trabalho e participa de palestras proferidas por várias áreas das empresas. 
Geralmente, a ambientação ocorre no Rio de Janeiro ou em Salvador. Os objetivos gerais da Ambientação são: Orientar novos empregados; Apresentar as áreas de negócio da empresa; Dar as boas-vindas; Disseminar a cultura da empresa; Explicar o processo de formação; Alinhar a postura desejada.

Como complementação à Dimensão Institucional, em 2007, foi criado o Projeto Cultura em Formação. Trata-se de um programa de treinamento que apresenta para os novos empregados um pouco da história e da cultura Empresa X. Foi concebido para atender às necessidades de inserção dos novos empregados em formação na cultura desejada pela empresa. Seus principais objetivos mais específicos são: Transmitir conhecimento acerca dos Valores, Comportamentos e Cultura Empresa X para os empregados em Formação; Reforçar a manutenção de valores fundadores e potencializar os valores emergentes que se mostrem adequados à cultura desejada pela Companhia; Compreender e gerar discussão junto aos novos empregados sobre a dinâmica da Cultura Empresa X; Pensar em conjunto o futuro da organização com relação aos pilares fundadores da Empresa; Reforçar a identidade Empresa X.

\section{b) Sobre a Dimensão Técnica}

Esta etapa tem por objetivo a complementação de conhecimentos para que os novos empregados desempenhem suas funções. Identificam-se as disciplinas que deverão ser mais enfatizadas, a depender do cargo, customizando o conteúdo, a ênfase e a carga horária ao perfil desejado para cada turma.

\section{c) Sobre a Dimensão Vivencial}

Trata-se da complementação dos conhecimentos teórico-conceituais, providos pelas demais dimensões, com vivência prática. Esta Dimensão tem por objetivos: Complementar os conhecimentos teórico-conceituais desenvolvidos pelas demais dimensões do programa, meidante estágios e visitas técnicas, com foco principal na Dimensão Técnica; Prover contato direto do treinando com a atividade profissional a ele destinada; Familiarizar o treinando com o "modus operandi" específico; Aplicar nos trabalhos desenvolvidos pelo(s) órgão(s) a teoria observada na Dimensão Técnica; Transmitir aos participantes a cultura 
organizacional da empresa; Possibilitar aos tutores e orientadores didáticos avaliar comportamentos dos participantes.

\section{d) Sobre a Dimensão de Gestão de Negócios}

Trata-se de um módulo opcional dos Cursos de Formação que pode ser aplicado para diferentes cargos, a depender da demanda específica das Áreas da Empresa. Abrange disciplinas das áreas de: Gestão Estratégica, Gestão de Pessoas, Geopolítica do Petróleo, Gestão Financeira e Orçamentária, entre outras.

\section{e) Processo de Distribuição}

Uma das etapas conduzidas pela Coordenação do Programa de Formação é o processo de distribuição dos empregados nas diferentes Áreas de Negócios da Companhia. Este processo ocorre a partir da escuta dos empregados e da análise e negociação entre as áreas envolvidas.

Buscando esforços para melhoria contínua, a Coordenação do Programa de Formação tem empreendido uma série de ações para encontrar mecanismos que tornem o processo mais alinhado aos interesses da Companhia, sempre visando à transparência e a satisfação dos seus clientes

\section{f) Formatura e Alocação Inicial}

Ao final do Curso de Formação, os empregados oriundos dos cursos de média e longa duração participam de uma Cerimônia de Formatura oferecida pela empresa. Em seguida, são transferidos, via documento interno da Empresa, para assumir seus cargos/funções. A apresentação de cada empregado ocorre de acordo com a negociação prévia realizada com o gerente do órgão de destino. 
5.

\section{Discussão dos Resultados}

Este capítulo apresenta a discussão dos resultados obtidos a partir das entrevistas realizadas com 16 profissionais, que participaram juntos - em uma mesma turma - do Programa de Formação de Empregados (Ambientação e Curso de Formação) antes de assumirem suas funções na Empresa X. Todos os respondentes tinham aproximadamente mais de seis anos de casa.

\section{1.}

\section{Análise de conteúdo}

A análise dos resultados da pesquisa foi dividida em quatro etapas: período anterior à entrada organizacional, período de participação na Ambientação e no Curso de Formação, período entre a alocação de fato na área e a data da entrevista e análise do processo de socialização sob a percepção dos empregados à luz das teorias de Van Maanen.

\subsection{1.}

\section{Período Anterior à Entrada Organizacional}

No início das entrevistas, os empregados foram questionados sobre as expectativas reais antes da entrada da na organização. Essas expectativas estão relacionadas a três categorias: fatores motivacionais para participar do processo seletivo público, imagem que tinham da Empresa e o que achavam que a Empresa esperava deles.

Vale relembrar que os novos empregados entram nas organizações com expectativas específicas e com a intenção de que se adaptarão àquela organização.

\section{Categoria 1: Fatores motivacionais para participar do processo seletivo público:}

\section{a) Pressão familiar/Influência de amigos}


A influência de amigos e família foi bastante citada pelos empregados como um fator motivador para se inscrever no concurso da Empresa X. Em dois casos específicos, a família além de incentivar, fez a própria inscrição do filho no processo seletivo.

"Tinha acabado de me formar e tal. E aí, o meu pai me inscreveu no concurso da Empresa X." (Entrevistado 3)

"Eu estava me formando e a minha mãe sempre queria que eu fizesse concurso e eu nunca quis. Então, eu fiz dois concursos: Empresa Y e da Empresa X. Só por fazer.” (Entrevistado 4)

"Minha mãe e meu padrasto falaram para eu fazer, me inscreveram e, inclusive, me levaram. Só não fizeram a prova para mim. Mas eu... Não achava que iria passar. Não tinha a menor expectativa." (Entrevistado 15)

“É, meu irmão já trabalhava. Minha mãe também e tal. Então, você fica tendenciosamente...”'(Entrevistado 13)

"Porque tinha um amigo meu lá na empresa, que trabalhava comigo, que ele resolveu fazer esse concurso..." (Entrevistado 9)

“(...) porque eu já namorei uma pessoa que tinha passado para Empresa $\mathrm{X}$ e a gente tava namorando nessa fase. Então, assim: eu só fiz o concurso por causa dele pra falar a verdade." (Entrevistado 6)

"Cara, na verdade, é o que eu conto pra todo mundo, eu não tava querendo fazer o processo seletivo público para a Empresa $\mathrm{X}$. Eu - na época - estava estudando para fiscal. E aí abriu o processo seletivo público e o meu irmão - que fez engenharia ficou me enchendo a paciência: Ah, vai lá! Se inscreva no processo." (Entrevistado 2)

\section{b) Sobre a estabilidade/segurança/salário}

Considerando que todos entrevistados já trabalhavam antes de entrar na Empresa $\mathrm{X}$ e que alguns deles tiveram experiência anterior em empresas privadas, verificou-se que a decisão de se prestar o concurso público para a Empresa $\mathrm{X}$ foi influenciada pela expectativa da estabilidade no emprego.

"Eu queria trabalhar em uma empresa que tivesse alguma, certa estabilidade. Eu conhecia pessoas também que falavam muito bem da empresa. Enfim, foi basicamente isso.”(Entrevistado 6) 
"Eu fiz o concurso por causa da idéia da estabilidade. É interessante. É importante para mim. Essa coisa de você ter um emprego bacana, digno e que, ao mesmo tempo, te dá uma estabilidade." (Entrevistado 12)

Outros entrevistados almejavam assumir cargo de nível superior, trabalhar como nível superior, na profissão para qual tinham se formado - Administrador, já que atuavam como nível médio na Empresa anterior.

"Foi um concurso que eu fiz para eu ter... como você não poderia, mesmo se formando administrador, galgar esse cargo na Empresa do grupo, eu tive que fazer um concurso fora." (Entrevistado 8)

"Porque era nível superior. E assim, eu sempre quis trabalhar na minha área. (...) Fiz mais por conta disso: de ter o meu cargo como nível superior.” (Entrevistado 14)

"Eu gostei porque abriu uma oportunidade pra mim, né?! De crescer; iria ser o primeiro emprego que eu estava conseguindo devido a minha formação escolar." (Entrevistado 2). maiores.

Ainda havia aqueles que já estavam trabalhando, mas almejavam salários

“Bom, eu buscava só uma renda maior.” (Entrevistado 8)

“Era mais estabilidade e salário." (Entrevistado 6)

\section{c) Recolocação no mercado de trabalho}

Foi possível observar também que alguns já estavam procurando emprego tanto na área pública quanto na privada e não tinham um direcionamento específico para a Empresa X.

"Eu fiz o concurso como um pool de concursos que eu fiz que incluía a Empresa X. Assim, como eu estava procurando emprego em várias outras empresas, eu também estava fazendo outros concursos. A Empresa $\mathrm{X}$ foi uma delas. Foi a que me chamou primeiro." (Entrevistado 5)

\section{d) Possibilidade de trabalhar com o que gostava/carreira}


Antes da entrada na organização, alguns esperavam usar os conhecimentos adquiridos na faculdade, trabalhar com o que gostavam e crescer profissionalmente até porque - por se tratar de uma Empresa do porte da Empresa $\mathrm{X}$ e que atua em diversos segmentos - as possibilidades de desenvolvimento de uma carreira bem sucedida poderiam ser alcançadas.

"E quando eu consegui vir para Empresa X, eu falei: "Poxa, eu vou conseguir trabalhar com RH." Embora, eu gostasse muito de área financeira também. Eu falei: "Ah, dá para ir para a área financeira também.”. Aí chegou lá, eu consegui ir para o RH, eu falei "Poxa, como é que deve ser trabalhar com RH, né?!" (Entrevistado 11)

"Então, eu tentei me alinhar primeiro em uma área que pudesse ser próxima daquilo que eu gostava de fazer e que pudesse com o tempo me levar à área onde eu gostaria de trabalhar que é a área financeira: parte de reestruturação de risco, reestruturação de dívida... Que eu vi bastante na empresa onde eu trabalhava e acho que a minha formação acadêmica foi mais voltada para isso. A expectativa que eu tinha era essa." (Entrevistado 5)

"(...) Mas eu sabia que a empresa era melhor, que talvez eu tivesse mais oportunidades para crescer." (Entrevistado 14)

"E aí o que abriu para mim: olha é o primeiro emprego que eu vou ter com meu curso superior. Vou poder colocar meus conhecimentos em prática. Vou poder fazer o que eu gosto. (...) E trabalhar em uma grande empresa que poderia me dar uma perspectiva de carreira muito grande." (Entrevistado 2)

\section{e) Possibilidade de voltar para Cidade Natal}

Em duas entrevistas, a expectativa girava em torno de voltar para a cidade Natal ou para a cidade onde gostaria de morar.

“(...) Mas eu tinha um interesse muito grande de voltar pra Salvador”. (Entrevistado 10)

"E o que pesou foi voltar para o Rio, né?! Eu tava bem, mas voltar para o Rio também seria bom. E o fato de ser a Empresa X, né?!" (Entrevistado 16) 
Com base nas citações acima, foi possível observar que as expectativas das pessoas antes da entrada na organização mesclam objetivos de carreira (trabalhar com o que gosta, atuar como nível superior; fatores circunstanciais ou relacionados ao ambiente de vida (ex: influência da família/amigos, estar procurando emprego), e vantagens que ela oferece (ex: estabilidade; salário).

\section{Categoria 2: Imagem que tinham da Empresa}

As informações que os entrevistados tinham sobre a empresa vieram, em grande parte, da mídia (propaganda, notícias na imprensa), especialmente para aqueles que não moravam no Estado onde a atuação da Empresa $\mathrm{X}$ é maior.

É o caso, por exemplo, dos entrevistados 1 e 4, residentes em Estados distantes geograficamente de onde está localizada a sede da Empresa X, que viam a empresa apenas como um posto de gasolina, sem ter o entendimento da sua amplitude de atuação.

"Então, a imagem que todo mundo tem do posto..." (Entrevistado 4)

A influência da mídia pode ser mais claramente observada quando os entrevistados citam a empresa como aquela preferida pelos universitários, a empresa dos sonhos, com possibilidade de equilibrar carreira e qualidade de vida.

"Mais de mídia mesmo. E nessas pesquisas, que a gente sabe quando é universitário. Ah, a Empresa $X$ é uma das empresas mais desejadas pelos universitários." (Entrevistado 7)

"Mas era a empresa dos sonhos mesmo. Assim, a questão de qualidade de vida junto com o emprego. Não só ralar, ralar, ralar e depois, do nada ser mandado embora e não ser valorizado." (Entrevistado 13)

Outro entrevistado também realçou a possibilidade de ser uma Empresa com um futuro promissor de grande crescimento, o que - segundo ele - representa a garantia do emprego para a vida toda.

"A imagem de uma empresa que já tinha um nome. Então, era uma empresa que tinha que crescer muito ainda e as descobertas acompanharam esse crescimento. Então, eu me vi com bastantes expectativas positivas. De ter ali uma empresa com a qual poderia crescer junto com vários desafios e que eu não via que 
essa empresa poderia ter alguma queda. Eu sempre vi que era emprego para a vida toda." (Entrevistado 8)

Por outro lado, os demais, por sua vez, já demonstravam ter alguma noção de que ela era uma grande Empresa, mas não conheciam profundamente suas áreas de negócio ou a complexidade das suas operações e inter- relações no mercado.

“É lógico que eu já conhecia a Empresa X e sabia que era a maior empresa do Brasil, mas não tinha tanto apelo assim lá em Recife, coisa e tal. Mas eu já sabia que era uma mega empresa. Lógico que a gente vê notícia, coisa e tal. E eu também sabia que é uma empresa inserida no mercado." (Entrevistado 12)

"A dimensão do tamanho, talvez, não, mas tinha uma noção que era uma grande empresa brasileira, né?!" (Entrevistado 15)

"Eu acho que para mim era uma empresa grande, maior do país na época, né?! E estável. Eu conhecia algumas pessoas que trabalhavam na Empresa X e, na época, eu cheguei a entrar em contato." (Entrevistado 16)

"A maior do Brasil. Uma das maiores, a maior da América Latina, uma das maiores do mundo. Mas não tinha noção do que ela é realmente." (Entrevistado 14)

"Eu sabia que era uma empresa de engenharia, basicamente. Eu só tinha uma idéia. Eu conhecia gente que trabalhava no centro de pesquisa e tudo." (Entrevistado 6).

Destaca-se também a visão de outro entrevistado que, por residir no Estado onde está localizada a Sede da Empresa X, alertou para a imagem de uma empresa que se preocupa com o desenvolvimento sustentável.

"Tanto no segundo grau como na faculdade, eu sabia que a Empresa $X$ era uma grande empresa. Sabia que ela era uma empresa de tecnologia de ponta. Mas, por outro lado, por morar no Rio de janeiro e ser impactado pelas atividades da Empresa X, né?! E as notícias que tem no jornal. Também sabia que tinha outro lado: que além de ser uma grande empresa, ter uma tecnologia de ponta, se preocupar com o meio ambiente, ela também, de vez em quando, produzia alguns estragos." (Entrevistado 2)

Até por ser considerada uma empresa do governo, havia ainda o estereótipo de repartição pública, de serviço lento e burocrático. 
"Eu acho que a Empresa X era uma grande empresa, mas ao mesmo tempo era uma estatal. E como toda estatal, a gente, eu, pelo menos, no meu mundo de PUC, achava que era aquela empresa muito burocrática, muito serviço público." (Entrevistado 15)

"Como uma estatal onde as coisas não aconteciam." (Entrevistado 5)

Por outro lado, outros já ressaltavam a possibilidade da Empresa apresentar características mais freqüentemente encontradas em empresas do setor privado até porque atua em um mercado bastante competitivo de óleo e gás e tem ações comercializadas na bolsa de valores.

"Eu imaginava que fosse mais perto do setor privado.Uma coisa assim desafiadora. Eu achava que não dava para ser igual a uma empresa pública. Aquela visão que a gente tem... que eu também não sei como é que é. Pode ser só um preconceito.” (Entrevistado 11).

Alguns também fizeram questão de esclarecer que não esperavam uma Empresa com características de setor público, estigmatizado por ser lento e/ou burocrático, mas sim, uma Empresa ágil e dinâmica.

"Até foi um dos motivos que me fez fazer o concurso da Empresa X. É uma empresa pública, mas não tão pública. Até por isso eu também fiz. Então, eu esperava uma agilidade, coisas mais rápidas e tudo mais, né?! De empresa privada mesmo. A coisa acontecendo mais de forma rápida!” (Entrevistado 3)

"Eu tinha até certo preconceito ... desse negócio de ser servidor público, sabe? Gente que trabalha em repartição. Aquele estereótipo, né?! Até um pouco de preconceito também. E eu tinha um pouco isso. E sempre fui um cara de mercado. Eu fiz administração. Sempre quis trabalhar em grandes empresas multinacionais. Antes da Empresa X, eu sempre trabalhei em multinacionais. (...) Então, sempre foi o meu perfil, né?! E aí, eu cheguei à Empresa $\mathrm{X}$ e vi essa possibilidade de juntar essas duas coisas: a estabilidade, que eu achava que era importante; uma segurança maior e, ao mesmo tempo, um perfil mais dinâmico, assim, de uma empresa que está inserida no mercado." (Entrevistado 12) 


\section{Categoria 3: Contra-Partida do Empregado}

A fase antecipatória da socialização consiste na fase anterior à entrada do indivíduo na empresa. Nessa etapa, são adquiridos conhecimentos sobre a organização e são formadas as expectativas a respeito do trabalho e da empresa (FELDMAN, 1976; GARAVAN; MORLEY, 1997).

Os entrevistados, em geral, tinham a expectativa de que a Empresa $\mathrm{X}$ aproveitaria a sua experiência anterior de trabalho, os conhecimentos específicos provenientes da sua formação acadêmica e o perfil profissional de cada um.

"Que eu já tivesse alguma bagagem de fora, se possível, né?! Até para agilizar o meu desenvolvimento. Creio que espera, até hoje também, que eu me desenvolva o mais rápido possível e possa dar continuidade ao trabalho do pessoal que saiu ou que está saindo ou está para sair em breve." (Entrevistado 9)

"Olha só. O que ela esperava de mim? Sinceramente, eu achava que ela queria que eu trabalhasse em uma área onde eu pudesse aplicar os conhecimentos que eu adquiri na faculdade. E aí, a minha expectativa até batia um pouco com o que eu achava que a Empresa X queria de mim. Pelo seguinte, apesar de ter feito uma faculdade de administração, quando fui fazer aquelas matérias que são eletivas, eu puxei todas as minhas matérias eletivas voltadas para análise econômica, para análise de preço. Enfim mais para a área econômica do que para a área de administrador." (Entrevistado 2)

"Então, até no currículo eu coloquei isso, porque eu tinha esse olhar de custo e tenho até hoje. Muito forte assim, né?! De você aproveitar melhor os recursos e tal. Então, no meu currículo, eu coloquei isso, que eu queria ajudar em algum programa de custo." (Entrevistado 11)

Em razão de alguns acreditarem que a Empresa apresentava características mais próximas do setor privado, um dos entrevistados achava que poderia contribuir para o crescimento da Empresa com a sua parcela de dinamismo. Vale destacar que essa convergência de características pode auxiliar o novo empregado a se sentir mais satisfeito e realizado no ambiente de trabalho.

"Eu achava que - com meu perfil de ser um cara dinâmico, que gosta de fazer as coisas de forma rápida, de ajudar e resolver todos os problemas rapidamente - eu poderia ajudar principalmente com relação à parte que o coordenador me 
chamou para trabalhar. (...) Então, é isso. Então, como eu achava que era uma empresa dinâmica, mais para o lado privado do que para empresa pública, eu achava que eu poderia ajudar com esse meu dinamismo." (Entrevistado 3)

Havia também a expectativa de que a Empresa investiria nos seus empregados, até mesmo, em razão do processo de socialização por que passaram. Os entrevistados acreditavam também que esse investimento deveria ser correspondido com dedicação, trabalho, resultados e novas idéias.

“(...) Eu já entrei com uma formação, achei que ela ia sugar o que eu tinha, o que eu tinha de bom e iria queria investir, continuar investindo em mim e a gente iria caminhar junto." (Entrevistado 8)

"Que eu iria trabalhar onde me mandassem; que eu poderia ter novas idéias, porque eu achava também que todo mundo que estava aqui era muito antigo.” (Entrevistado 1)

"Tentar fazer o seu trabalho, tentar fazer bem, buscar desenvolver o trabalho de uma forma legal e trazer bons resultados. Essa é a minha contribuição." (Entrevistado 12)

\subsection{2.}

\section{Período da Ambientação e do Curso de Formação}

Quando entraram na Empresa, os entrevistados passaram por aproximadamente duas semanas na Dimensão Institucional do Programa de Formação de Empregados, também conhecida por Ambientação. Nessa etapa, eles participaram de palestras proferidas por várias áreas da Empresa $\mathrm{X}$, o que representou o primeiro acesso deles à Cultura e aos valores da Empresa. Entre os principais objetivos da Ambientação, estão: orientar novos empregados, apresentar as áreas de negócio, disseminar a cultura, explicar o processo de formação e alinhar a postura desejada.

Para Boog, Casado e Dutra (2006), na medida em que as empresas explicitam os seus valores corporativos e os alinham à sua visão estratégica, há o estimulo pela aderência do empregado e por sua identificação com os objetivos da Empresa. 
Por outro lado, ainda que a intenção da Companhia tenha sido de transmitir os valores às pessoas, buscando os benefícios dessa nova relação em prol da identificação e da confiança (BARRET, 2000), o sentimento de muitos com relação às palestras proferidas durante a Ambientação foi o de que houve uma intenção da Empresa X em persuadi-los frente apenas aos aspectos positivos que a organização possui, buscando imprimir seus valores e sua cultura. Para alguns, houve o sentimento de exagero, um excesso de valorização da Empresa. Para outros, a conceituação de mundo ideal, de melhor empresa para se trabalhar, omitindo os pontos de melhoria da Empresa, conforme destacado pelo entrevistado 4.

\section{Categoria 1: Ambientação como lavagem cerebral}

"Só que eu acho assim, que tem muita coisa que não é verdadeira. Eu acho que a gente chega com uma visão, né?! De que a empresa, como é que eu vou dizer, eles fazem tipo uma lavagem cerebral na gente. Existe um excesso de valorização em relação à empresa e na ambientação, principalmente, eles tentam fazer uma lavagem cerebral, entendeu?" (Entrevistado 6)

"Eu senti assim: primeiro, que aquilo ali, a Ambientação, é uma espécie de lavagem cerebral, né?!” (Entrevistado 16)

"A única crítica que eu faço é que a gente só vê o lado bom, da ambientação e tudo. Então, as coisas assim: você não vê as dificuldades, né, das áreas. Que comentam, falam. Várias áreas, que eu me lembre. É acho que seria válido, sim. É também é mais para você conhecer os benefícios da empresa e tudo. As dificuldades que eu digo também são cabíveis naquele momento.” (Entrevistado 4)

"Porque na palestra é como se fosse um mundo de sonhos. Todo mundo vai ter uma oportunidade para conseguir alguma coisa melhor, sabe? Você vai trabalhar no que você gosta. Você vai... Nossa! Você vai estar totalmente envolvido, vai vestir a camisa." (Entrevistado 13)

"Eu não sei. (...) Eu confesso assim que a ambientação, o nosso curso de formação, eu tenho um pouco de dificuldade, assim, de até aonde um ia e até onde o outro ia. Por quê? Na verdade, eu acho que ali, eles passam uma coisa, para mim, foi a mais forte de todas, que é, assim: você está numa boa companhia, está na maior companhia brasileira. E vocês estão num lugar no suprasumo. No melhor. Então, eles vendem uma coisa muito forte de 
tipo: Caramba! Vocês estão na maior companhia brasileira para se trabalhar." (Entrevistado 15)

\section{Categoria 2: Ambientação válida e oportunidade para conhecer a Empresa}

A ambientação foi válida para quase todos os entrevistados, com exceção do Entrevistado 8 que, em razão de já ter trabalhado em uma das empresas do grupo, pouco aproveitou as informações fornecidas durantes as palestras, até porque grande parte do que foi exposto, ele já conhecia.

Para os demais, a Ambientação representou uma válida oportunidade para se conhecer a Empresa. Como a empresa é grande e atua em vários segmentos, o Curso de Formação foi considerado também importante para propiciar o entendimento da visão do todo.

A partir da Ambientação e do Curso de Formação, pode-se inferir que a transmissão da cultura ajudou os novos entrantes a conhecer melhor a empresa. Segundo Kristof (1996), a cultura organizacional tem sido identificada com um conceito que pode ser utilizado para compreender o funcionamento das organizações.

Esse entendimento é reforçado pelo entrevistado 12 que ressalta que, no caso daqueles indivíduos que entraram diretamente na área, provavelmente só conheceram o seu trabalho específico e tiveram dificuldade para compreender o tamanho da Empresa e a interface entre os processos e as áreas.

“(...) Uma forma mais próxima de conhecer a empresa. Foi algo muito genérico pra gente, né?! Mas eu acho que foi produtivo sim, ainda mais pra mim que conhecia muito pouco da empresa, né?!" (Entrevistado 3)

"Ambientação valeu. Eu achei que foi legal. Você conheceu a empresa ali." (Entrevistado 4)

"Cada área vai lá, apresenta, mostra o que é. Isso é muito importante. Você vai ter uma visão. Cada pessoa tem uma visão mais geral porque se você entra e vai direto para aquela coisinha lá que... "Ah, eu vou fazer pagamento de fornecedor aqui no SAP. O cara entra e vai direto para ali fazer a transação, ninguém explica e o cara vai fazendo, o portal e tal. E o cara não sabe onde é que ele está, entendeu? O cara não sabe qual é o contexto dele ali, entendeu? O tamanho da empresa, quais são as áreas, quem me manda nisso, isso aqui vai para onde, sabe? Essa visão 
eu acho que é muito importante. Até para o cara fazer o trabalho dele legal e enxergar outras coisas. E ter novas idéias, não é? Ter uma visão holística. Então, eu acho que é importante, que a ambientação dá essa visão mais ampla da companhia. Que cada área vai lá e apresenta. Mostra um cuidado também com o empregado. Então, eu achei muito bacana como a Empresa X recebe seus empregados." (Entrevistado 12)

“(...) sendo bem sincero, a ambientação eu achei legal porque ela agregou no sentido de mostrar realmente um pouquinho de cada área da Empresa X.” (Entrevistado 2)

Foi ressaltada a importância da Ambientação também para informar e esclarecer o tamanho e a amplitude de atuação da Empresa X, incluindo suas áreas de negócio, já que opera tanto no Brasil quanto no Exterior.

"Por causa do porte da empresa e da diversidade, né?! Tem Empresa $\mathrm{X}$ em todos os lugares praticamente aqui do Brasil e em vários lugares do mundo. Então, uma empresa muito grande e muito complexa. E eu acho que isso facilita." (Entrevistado 9).

\section{Categoria 3: Ambientação como forma de buscar o alinhamento cultural}

Além de ajudar a conhecer a Empresa X, a Ambientação foi destacada como uma oportunidade para se alinhar expectativas dos entrantes às necessidades da Empresa, fazendo com que o recém-admitido se sentisse parte daquela cultura.

Nesse sentido, vale a pena citar O'Reilly (1989) que vê a cultura como grande facilitadora da adaptação do indivíduo a uma determinada organização de forma que ele se sinta confortável.

"Acho que é importante se servir para a orientação do novo empregado. Porque também sei que em uma estatal é mais difícil por conta do concurso público, né?! Se alinhar totalmente as suas expectativas profissionais com a necessidade da empresa. Mas se aquilo auxilia o empregado a se alocar melhor na empresa, acho bem legal." (Entrevistado 5).

"É, abriu um leque de informações, até porque, antigamente, eu tinha aquela visão de fora. Agora, eu faço parte, né, da empresa. Enfim: eu faço parte, sei lá, de botar gasolina no posto, até chegar esse processo, né?! O final. Enfim, me senti inserida no processo." (Entrevistado 7) 
No entanto, outros criticaram a duração da Ambientação, pois foram fornecidas muitas informações sobre a Empresa e o seu negócio e nem tudo foi possível absorver.

“As pessoas vão lá e passam as experiências delas. Só acho que é tudo muito longo, né?! Eu não via necessidade de durante três semanas você ficar ali, mas é valido.” (Entrevistado 7)

“(...) A ambientação é uma coisa meio vomitada, né?! Porque de manhã é uma palestra, de tarde é outra. Às vezes, duas palestras de manhã. Às vezes, duas, três à tarde. E informação, informação, informação que você não consegue, às vezes, né, captar tudo." (Entrevistado 1)

\section{Categoria 4: Amor e Nacionalismo como resultados da Ambientação}

Ao compartilhar as informações sobre a área de negócio da qual faziam parte, os palestrantes buscavam demonstrar o orgulho que sentiam de trabalhar na Empresa X.

Praticamente todos os candidatos destacaram o vetor amor pela Empresa como característica comum dos palestrantes. Outros empregados até se surpreenderam com o ritual de tocar o hino durante a Ambientação, o que demonstra a presença de mais um vetor: o nacionalismo, destacado pelos entrevistados.

"Sim, eu lembro que durante o curso de formação praticamente todos os palestrantes que iam lá começavam basicamente as aulas falando sobre o orgulho, sobre o histórico da Empresa X, né?!" (Entrevistado 3)

"Então, ali você já tem o primeiro contato. E ali, você já entra no mundo maravilhoso da Empresa X, né? E ali, onde vão falar aquelas pessoas mais é... digamos, assim, mais...apaixonadas. Eles escolhem a dedo, né?! Então, não vai botar ninguém ali para reclamar da Empresa X. Vão colocar ali pessoas que te inspirem, né?" (Entrevistado 16)

"Eu lembro que tinha alguns palestrantes que eles entravam lá, assim, quase chorando, falando que estavam muito emocionados de falar. Eu acho que eram quase trezentas e cinqüenta pessoas naquela ambientação.(...) que novos entrantes, que aquilo era muito bom para empresa, que ele amava aquela empresa e ... (...) Todos os professores eram apaixonados. Passavam aquela 
imagem de Empresa $\mathrm{X}$ dentro do coração, assim, né?!" (Entrevistado 1)

"E uma coisa que marcou que ele falou é... que a gente não tinha que ter sangue nas veias, o que corria nas veias dele era o petróleo." (Entrevistado 2)

"Uma coisa que me marcou muito, agora eu to lembrando, é que logo no primeiro dia, tocou o hino nacional. Nossa aquilo foi emocionante. Eu só não chorei porque eu falei: caramba! Não, tenho que me segurar." (Entrevistado 7)

"Logo de cara, foi no primeiro dia da nossa ambientação. Quando tocou o hino nacional, eu falei: ih, caraca! Eu achei logo assim estranho, engraçado. Assim, esse negócio de nacionalismo; vamos cantar o hino." (Entrevistado 9)

“Aquele lance de tocar o hino. É eu achei engraçado, né?! Mas a gente já tinha ouvido falar nisso: Ah, todo evento na Empresa X, toca o hino porque é uma empresa brasileira e não sei o quê.E você enxerga muito nas pessoas que vão lá falar, que normalmente são esses caras com mais tempo de casa, que tem a empresa mesmo na veia assim ..." (Entrevistado 12)

"Era exatamente desse ponto que eu ia falar. Da questão do nacionalismo mesmo; do orgulho de ser Empresa $\mathrm{X}$, de ser petroleiro, de trabalhar em uma grande companhia. E eu sentia, sentia. É, eu lembro a gente no Edihb ainda, antes de ir para Salvador, que foi quando teve a auto-suficiência." (Entrevistado 14)

\section{Categoria 5: Ambientação e Curso de Formação como Rede de Contatos}

Para os entrevistados, o relacionamento entre os participantes do Curso e com palestrantes e professores foi considerado um aspecto positivo. As amizades construídas durante o período do curso foram identificadas como a parte mais importante e proveitosa do treinamento.

Em razão do tamanho da empresa, essa rede de contatos tem sido útil, em diversos momentos, no desempenho das atividades do indivíduo para conseguir informações de trabalho mais ágeis.

"Mas achei que foi válido sim. Ainda, principalmente, porque a gente criou um grande leque, uma rede de amizades, na verdade. Redes de relacionamentos na Empresa X, né?! Que até hoje continua." (Entrevistado 3) 
"E outra coisa é o lance do relacionamento assim... É muito bacana você já entrar na empresa conhecendo sessenta pessoas que se espalharam ali em algumas áreas e realmente a gente usa isso. Eu não sei você, mas eu já usei.” (Entrevistado 12)

"Eu acho assim que o maior ganho no curso de formação, no meu entendimento, foi a questão do networking que a gente formou. Foi, assim, a questão dos contatos que eu vejo. Quando eu entrei no $\mathrm{RH}$, muita coisa que eu precisei, eu liguei para as próprias pessoas da nossa turma, porque a maioria foi para o $\mathrm{RH}$ também.” (Entrevistado 13)

"O meu curso de formação valeu muito mais pelas relações que eu fiz no curso do que pela parte de conteúdo." (Entrevistado 15)

"Valeu pela questão do contato, né?! Da rede de contatos, de você conhecer, inclusive, outras pessoas mesmo. Os palestrantes, lá eu conheci o meu ex-Gerente. Então, assim, esses contatos... A profissional que deu aula para gente da parte de estratégia, ate hoje..." (Entrevistado 11)

Após a Ambientação, os recém-admitidos passaram pela Dimensão Técnica do Programa de Formação de Empregados, também conhecida por Curso de Formação, na qual são fornecidos os conhecimentos complementares necessários ao desempenho de suas futuras funções.

\section{Categoria 6: Curso de Formação: validade, formato e aproveitamento}

O Curso de Formação foi considerado bastante válido e proveitoso pela maioria dos entrevistados no sentido de propiciar conhecimentos mais específicos sobre o negócio da Empresa X.

"Sim. Foi ótimo! Eu achei sensacional. Eu acho que se eu tivesse entrado aqui sem o curso de formação, não teria sido a mesma coisa porque a gente conheceu muito. A gente via como as pessoas falavam. Ok! Que depois, algumas coisas a gente viu que eram diferentes. Mas, assim: eu não sabia nada da Empresa $\mathrm{X}$ antes. Nada. Eu nem imaginava como é que funcionava. Que tinha uma área de ABAST, uma área de E\&P, uma área de Serviços compartilhados. E a gente foi conhecendo um pouquinho de cada uma." (Entrevistado 1)

"Aí sim, eu acho que a gente começou a ter uma noção do que é a Empresa $\mathrm{X}$ ali nas aulas. Durante as aulas do negócio principal da Empresa $X$ que a gente sabe o que é petróleo, mas não sabe a 
fundo Não é só petróleo, é energia. Então, eu acho que foi válido sim." (Entrevistado 14)

“(...) Então, eu acho que o curso de formação tem muito valor, sim. Tem seu valor, dá uma visão da empresa, uma visão holística. A gente vê diferença, vê ganhos da gente que entrou como júnior do cara que entrou como pleno ... que não passou por aquilo. E os caras... Sabe? Tem umas coisas assim... Os caras não sabem nem qual é o caminho das pedras, o quê fazer, quem faz o quê, quais são as áreas que existem, os caras não sabem isso. Então, às vezes, o júnior tava dando um banho nos plenos, que entraram perdidos na empresa (...) $O$ curso de formação também dá muita visão.Dá muita. Legal. Da mesma forma, vão todas as áreas lá... Aqui, você têm várias disciplinas e aí, vão as áreas, os palestrantes... Os professores são, normalmente, das áreas. E aí, os caras trazem a visão da área, explica, fala, traz a sua experiência da Empresa X..." (Entrevistado 12)

\section{Categoria 7: Curso de Formação como revisão de conceitos}

Por outro lado, muitos argumentaram que não haveria a necessidade de revisar os conceitos e conteúdos estudados por eles na faculdade novamente durante o Curso de Formação, pois já que haviam passado por um processo seletivo público para o cargo de Administrador, ficava subentendido que os conhecimentos básicos da profissão já possuíam.

\footnotetext{
"Ah, sinceramente, não achei nada valido porque eu achei que, na maioria das matérias, era uma revisão da faculdade." (Entrevistado 7)
}

"Eu não sei como são os cursos de formação e nem como foram os das outras turmas, mas eu achei que o nosso curso de formação foi muito acadêmico. Foi aquilo que você viu na faculdade, você viu de novo no teu curso de formação lá em Salvador. E foi como uma revisão bibliográfica de todo o curso que você teve, né?! Então assim, eu achava que - pelo menos no curso de administrador - deveria tentar trazer um pouquinho da prática da Empresa $X$; do que a Empresa $X$ espera do administrador; o que vai fazer aqui dentro para passar isso no curso de formação. Coisa que hoje isso não acontece, quero dizer, no nosso curso não aconteceu. Então assim, eu não vi muito valor para ser agregado para gente ali."(Entrevistado 2)

"Eu vi o curso de formação mais como uma revisão, né, de conteúdos. A revisão de conteúdos que a Empresa $\mathrm{X}$ se foca, né?! 
Já era a nossa grade. Então, era mais uma revisão." (Entrevistado 4)

"É. Foi totalmente, no meu conceito, uma revisão do que eu vi na faculdade." (Entrevistado 13)

“(...) Bom, olha só, o curso de formação do administrador, assim como é na nossa faculdade de administração, ele foi bem amplo. Foi dada de novo, igual à faculdade, uma visão geral, mas não muito aprofundada sobre vários itens. Vários conceitos. Isso serve para mim apenas para saber com o que eu gosto de trabalhar e com o que eu não gosto.” (Entrevistado 8)

"O curso de formação é importante. Agora, acho que mais importante para algumas carreiras e menos para outras. Para administrador, eu acho que podia ser uma coisa muito mais enxuta assim. Porque a gente acaba vendo muita coisa de administração que a gente já viu na faculdade, óbvio, e que não tem nada específico para a Empresa $X$. Ah, então vai falar de... Sei lá. Motivação, não sei o quê. Sabe? Liderança, não sei o quê. Não tem nada. Nada de novo do que é aplicado, especificamente, à Empresa X. Acho que o curso de formação, ele poderia ter esse foco customizado, específico para a Empresa X." (Entrevistado 12)

Em razão do Curso de Formação ter sido considerado, por grande parte dos candidatos, uma revisão de conceitos, muitos sentiram falta de conhecer como seria o trabalho na prática, como seria a Cultura da Empresa $\mathrm{X}$, seus processos e forma de trabalhar.

Uma das opções sugeridas pelos candidatos seria definir a alocação inicial antes da realização do Curso de Formação, de forma que as matérias oferecidas no Curso pudessem ser customizadas conforme o perfil de cada vaga.

"Mas eu achei que o curso foi muito longo diante do que precisava mostrar, entendeu? Porque a gente tinha acabado, muita gente tinha acabado de se formar, né?! Então meio que viu coisas de novo que tinha acabado de ver. Podia ser mais específico. As matérias. Então, podia ser um pouco mais focado na gestão da Empresa X.Como é o trabalho do administrador na Empresa X? O dia-a-dia na Empresa X?" (Entrevistado 3)

"Se você entra na Empresa $X$, fazendo uma prova de administração, significa que você tem um conhecimento mínimo de administração, certo? Então, não sei. Essa parte, assim, não tem que passar conteúdo de administração. Eu acho que tem que 
passar assim: como que é feita a gestão. Já está todo mundo nivelado. Você tinha que entender como acontece os processos dentro." (Entrevistado 15)

"Apesar de achar ele fraco (...) O que a gente imagina? $\mathrm{O}$ que eu imaginei? Bom, sou administradora. Então, eu não iria ver coisa básica do administrador. $O$ que eu imaginava? $O$ que um administrador dentro da Empresa $\mathrm{X}$, de uma cultura da Empresa $\mathrm{X}$ pode fazer. Algumas coisas eu achei que a gente até viu, mas outras eu achei fraco, eu achei que a gente poderia ter feito mais dentro da cultura. Os próprios módulos do $\mathrm{RH}$ foram externos à companhia." (Entrevistado 10)

"Agora, talvez eu não sei se poderia ser uma coisa viável, mas poderia ser é mais focado, sabe?! A partir do momento em que você sabe para onde vai, talvez, se fosse possível definir a vaga. E, mais ou menos assim, fazendo por segmento. Poderia ser uma coisa mais otimizada, né?! Por aquilo que a gente absorveu, poderia ser mais otimizado.” (Entrevistado 16)

"Acho que foi legal, mas acho que administrador não precisa de curso de formação porque a gente faz um curso de formação genérico de novo, como se fosse outra faculdade e sem saber onde você vai trabalhar. Então, assim, se de repente definisse a locação e você fizesse capacitações direcionadas para a área. Para que eu fiquei vendo matemática financeira lá no curso de formação assim?” (Entrevistado 11)

"O que eu acho é que, em minha opinião, as vagas teriam que ser definidas antes, porque se eu soubesse que eu viria para a contratação, eu iria fazer um curso especifico.” (Entrevistado 7)

"Eu acho que ali, não tem que voltar a ensinar o que se aprendeu na faculdade. Não, não tem. Porque algumas vezes você teve que pensar em matemática financeira. Pois é! Eu acho que quem for para essa área financeira, pode rapidamente ganhar um curso complementar dessa área e ficar apto para trabalhar. Não precisa fazer um curso de formação para ir todo mundo. Então, ali naquele curso de formação para todo mundo. Tem que ter as lições essenciais." (Entrevistado 8)

Por outro lado, uma minoria considerou que a revisão de conceitos que ocorreu durante o Curso de Formação foi bastante positiva. Uma explicação para isso seria o fato do entrevistado já ter se formado há um tempo e, portanto, a revisão de conceitos foi importante para fazê-lo relembrar do conteúdo aprendido durante a faculdade. 
"Eu tava muito tempo afastada da administração e quanto às matérias eu achei bastante interessantes, principalmente, aquelas voltadas para a área de negócio da Empresa $\mathrm{X}$ e até as próprias matérias do curso de Administração comum. Pra mim, foi uma revisão boa e tudo." (Entrevistado 6)

Considerando que a Dimensão Vivencial faz parte do Programa de Formação de Empregados e visa prover contato direto do treinando com a atividade profissional, parte da complementação dos conhecimentos teóricoconceituais pode ter ficado comprometida, conforme destaca a entrevistada 14 .

"Teve muita revisão. Teve revisão de conceito, coisa que a gente aprende na faculdade. Achei válido porque trouxe a teoria, que a gente aprende na faculdade, para a prática da empresa. Achei isso interessante. E para mim, que estava recém-saída da faculdade, foi muito bom. Foi uma grande revisão. Agora, o que eu achei da nossa turma perdeu foi a questão do vivencial que a gente não teve, né?!” (Entrevistado 14)

\section{Categoria 8: Principais pontos destacados sobre o conteúdo das palestras durante a Ambientação e as aulas do Curso de Formação}

Considerando que Johann (2006) entende ser fundamental conhecer a cultura da organização para evitar barreiras e aproveitar oportunidades, entre os pontos destacados pelos entrevistados, tem-se a exposição da missão e da visão da organização repetidas várias vezes durante as apresentações, conforme destacaram os entrevistados.

\footnotetext{
"Ah, eu lembro que todo mundo que chegava lá, mostrava a missão, os valores. Qualquer aula que fosse dada. Eu lembro... Eles sempre faziam referência à missão, à visão da Empresa X." (Entrevistado 6)

"Missão e visão todos falavam, mas eu não lembro se teve uma palestra." (Entrevistado 1)
}

Pelos discursos transcritos a seguir, a Empresa $\mathrm{X}$ buscou assegurar a abordagem dos seguintes temas: gestão de SMS, Segurança da Informação, Ética e Responsabilidade Social durante as palestras da Ambientação bem como durante as aulas do Curso de Formação. Isso pode demonstrar, na nossa visão, que a 
Empresa $\mathrm{X}$ objetivava transmitir alguns de seus valores organizacionais por meio das palestras ocorridas durante a socialização de novos membros.

\section{a) Gestão de SMS}

Com relação à Gestão de Segurança, Meio-Ambiente e Saúde, os entrevistados lembraram que a imagem da Empresa $\mathrm{X}$ transmitida foi a de uma organização que se preocupa com essas questões.

"É... Eu lembro que a gente tinha que preservar a imagem da empresa, né?! (Entrevistado 7)

"Que foi a apresentação do pessoal do SMS. Então, eles tentavam passar uma imagem de que a empresa operava com bastante segurança nas plataformas, enfim... Que eles se preocupavam muito com segurança dos empregados. Não dos empregados, né?! Mas da força de trabalho que eles é... Além de se preocupar com a segurança da força de trabalho, eles se preocupavam também com as comunidades do entorno, com programas, assim..." (Entrevistado 2)

\section{b) Segurança da Informação}

Tanto nas palestras da Ambientação quanto nas aulas do Curso de Formação, os empregados lembraram que receberam inúmeras recomendações sobre o comportamento ético que era esperado deles e o zelo que deveriam ter com as informações oficiais da empresa.

"Lembro de segurança, que foi um cara lá na ambientação também coronel não sei o quê, comandante não sei das quantas... Acho que era uma cara do GAPRE lá. Também eu lembro a palestra dele. Mas segurança da informação, eu lembro porque chamou muita atenção quanto que a Empresa $X$ chama atenção para isso: segurança da informação. Impressionante." (Entrevistado 12)

"A questão do alpinismo social, muito forte: de assim você estar no metrô tomando cuidado com quem você fala. Que é normal, né?! Você está super empolgado." (Entrevistado 11) 
Por outro lado, apesar do discurso demonstrar a preocupação da Empresa X com a política de segurança da informação e, até mesmo, com a questão da espionagem industrial, muito do que foi exposto, não pôde ser observado no dia a dia.

“É... É meio over. Que depois que você está aqui, ai você: ah, ta bom! É assim, mas ninguém se liga nisso na verdade. Ninguém está ai para isso. Todo mundo deixa o computador ligado. As pessoas passam a senha um para o outro. $\mathrm{Na}$ verdade, é isso que acontece. Fazem um terrorismo...que faz parte do. processo de choque, né?!” (Entrevistado 16)

\section{c) Ética e Responsabilidade Social}

Os valores: Ética e Responsabilidade Social também foram citados pelos candidatos. Para Tamayo, Mendes e Paz (2000), os valores representam princípios relativos a modelos de comportamentos desejáveis. Ou seja, grandes influenciadores dos comportamentos e das atitudes dos indivíduos (MEGLINO; RAVLIN, 1998).

"É. Eu acho que o código de ética foi passado, foi colocado... Então, ali já tava mais ou menos a ética da empresa." (Entrevistado 6)

"Me lembro de que falavam do código de ética, mas depois teve uma reformulação do código de ética. Depois que a gente entrou." (Entrevistado 10)

"É, acho que teve. Teve sobre valores organizacionais, sobre ética, responsabilidade social... Eu acho assim que mais marca aqui na Empresa X é essa questão da responsabilidade social." (Entrevistado 13)

"Foi uma também que eu não tinha idéia... De responsabilidade social. Também que tava meio na moda, tava começando... Na verdade assim... Falando, né?! Do balanço social da Empresa X, eu lembrei essa." (Entrevistado 6)

A partir da abordagem dos temas durante o processo de socialização, podese inferir que a Empresa buscou transmitir sua cultura e valores a fim de direcionar o comportamento dos empregados em prol do alcance dos objetivos organizacionais. 


\section{d) Qualidade de Vida e Preocupação com o Empregado}

Outro ponto destacado pelos entrevistados foi o equilíbrio entre vida pessoal e profissional. Eles esperavam além de trabalhar, ter tempo fora da empresa para assuntos pessoais. Ficou evidente a preocupação da empresa com o bem-estar do empregado como valor para a Companhia.

Os empregados classificaram esse valor como positivo para o alinhamento indivíduo-organização. Quando as pessoas entram para uma organização encontram valores que podem ser similares ou não aos seus, ocorrendo o que Barret (2006) denomina de "alinhamento de valores", variável que, segundo ele, impacta diretamente nos resultados da empresa.

"Porque na Empresa onde eu trabalhava era você ralar de trabalhar 24 horas por dia, o tempo todo trabalhando e sem nenhuma, sem grandes benefícios, né?! Quanto que, na Empresa $\mathrm{X}$, é o inverso, você trabalha ... A vida é uma coisa, o trabalho é outra. Separa bem as coisas e tal. Que a Empresa X é mais uma coisa cultural é tipo faz parte da sua vida, né?! A minha empresa anterior não, é o seu trabalho, entendeu?" (Entrevistado 3)

“Ah, uma imagem muito positiva, né?! Que valorizava os empregados e tudo. Que estava muito preocupada com a diversidade cultural, né?!" (Entrevistado 6)

"Olha, a Empresa $\mathrm{X}$ tem uns valores que são interessantes, né?! Essa coisa do o respeito ao empregado. Eu valorizo muito isso e eu enxergo isso, tá? Respeito aos direitos, né?! Aqui, pelo menos, eu consigo equilibrar bem a minha vida pessoal com a minha vida no trabalho." (Entrevistado 12)

"Sim. Qualidade de vida, né?! Uma empresa que se preocupa sem duvida com o bem estar. A satisfação. Eles sempre falavam isso, mas assim, priorizando, o interesse da Empresa X. É fato isso, né?! Ninguém está ali para fazer caridade." (Entrevistado 16)

\section{e) Perfil do Empregado Padrão Empresa X}

Para Chatman (1989, 1991) e Bhargava e Mathur (2002), os valores organizacionais, núcleo da cultura organizacional, direcionam comportamentos, atitudes e julgamentos, diferenciando uma organização de outra. 
Com relação à empresa em estudo, foi questionado aos entrevistados se haveria um perfil de empregado padrão e o que valeria a pena destacar sobre esse perfil. Alguns comportamentos foram identificados, permitindo-nos inferir sobre características presentes na cultura.

Para alguns empregados, ver o empregado bem assistido em termos de plano de saúde e benefícios gerais significa uma cultura que valoriza o empregado, cuidando do seu bem-estar dentro e fora da Companhia, resquícios de uma Cultura Paternalista.

\section{e.1)Bem cuidado}

"Eu via o empregado petroleiro extremamente bem cuidado." (Entrevistado 16)

Ficou claro para outros que o empregado precisa ter compromisso com o seu trabalho, esforçando-se para realizar suas tarefas de forma a atender as necessidades da Companhia.

"É você ter um compromisso do qual a empresa precisa ou o que está sendo esperado de você; você está comprometido com o esforço que você tem que dar." (Entrevistado 4)

“(...) Eu acho que assim: que tenha disciplina, que esteja envolvido, compromissado, né, com as suas tarefas, com o que lhe é designado. Então, assim, sua responsabilidade é essa. Então, você tem que fazer aquilo e, de repente, até fazer mais um pouco para mostrar que você está, né?!" (Entrevistado 15)

Ainda durante a Ambientação, vários participantes ressaltaram o que a empresa esperava deles: seriedade e obediência, revelando parte de uma Cultura Hierárquica e Obediente.

"Na verdade, essa parte de comportamento eu lembro mais de um dos palestrantes, das falas dele. Eu acho que a fala dele era como se você tivesse em qualquer outro emprego. Eu acho que ninguém está aqui de brincadeira. Aqui é como se fosse uma empresa como outra qualquer. Vocês têm que vir com uma roupa adequada." (Entrevistado 15)

"Eu me lembro dele. (...) não tem como...(...) mas ele passava um papel de seriedade muito grande assim, do que ele fazia, sabe?" (Entrevistado 11) 
"É... Eu lembro que tiveram muitas palestras de recursos humanos, tinha aquele palestrante que vinha falar sobre todas as regras do curso de formação, regras de comportamento no curso de formação, com relação ao cumprimento dos horários. Ele contou as experiências: o que é certo, o que é errado... (...) Ele tinha uma postura meio "policialesca" de diretor de escola, mas era essencial para as pessoas que entravam ali porque muitas não sabiam se comportar mesmo. Eram novos, não tinham experiência ..." (Entrevistado 5)

"Ah, uma coisa que marcou foi aquele palestrante falando para gente o tempo inteiro o seguinte: Oh, vocês vão fazer o curso de formação na Bahia. A sala de aula de vocês vai ser no próprio hotel, mas ali vocês estão trabalhando. E vocês têm que manter a postura como se estivessem dentro das instalações da Empresa X. É, eu me lembro disso. Vocês têm que manter uma apresentação. Vocês têm que sair vestidos como se fossem trabalhar, etc. Então, isso aí eu lembro. Agora, chegar e falar que pegou aquele mapa que a gente tem aqui de cultura, que eu acho, sete ou oito, sei lá quantos valores...Não!"(Entrevistado 2)

\section{e.2)Obediente}

"Parece que sei lá tinha um moldizinho lá que eu tinha que vestir pra ser aquele funcionário padrão Empresa X. (...) Uma pessoa assim, que era sempre muito certinha; seguia a risca determinado comportamento, aquela cultura, normas. (...) Bem regime militar mesmo.” (Entrevistado 9)

"Para eles, tem que ser uma pessoa que não tenha opinião própria, que não fala, que é todo certinho..., então eu acho assim que aceita todas as ordens, sem titubear." (Entrevistado 1)

\section{e.3) Orgulhoso da Empresa}

Mais uma vez, foi ressaltado o amor pela Empresa e pelo país como um vetor compartilhado entre os empregados. Sentir orgulho da empresa é um dos valores patrocinados pela Empresa X.

"É. Coisa de você contribuir para o desenvolvimento do país. Aquela coisa de contribuir para atingir as metas do país, da Empresa X. Não assim do indivíduo, sabe? (...) precisa cumprir suas metas, né?! De negociadas no ano tal e não o que lá... Uma coisa que mexe mais com o sentimento. Aquela coisa que você é movido pela paixão e tal." (Entrevistado 16) 
Entrevistador: Você consegue ver características de um empregado padrão da Empresa $\mathrm{X}$ ?

Entrevistado: "Eu consigo, principalmente, no orgulho. Eu não conheço ninguém, assim, que trabalha na Empresa $X$ que fale assim: Nossa! Que não esteja satisfeito, sabe? Que não tem orgulho. Que não está satisfeito, realmente, com a remuneração, com os benefícios. Assim, é difícil... Claro que você vai encontrar um ou outro que não está satisfeito, mas no fundo, tem consciência das vantagens, né?! Não é todo emprego que te dá uma PLR boa todo ano. Pois é... Mas, então, a maioria, a grande maioria dos petroleiros, eu vejo que estão satisfeitos, tem orgulho de trabalhar na empresa, defendem a empresa." (Entrevistado 14)

"Ah, eu acho que o empregado padrão, ele tem orgulho de trabalhar na Empresa X, apesar de reclamar, né?! Vamos dizer assim: Ele é, faz parte. É inerente ao petroleiro." (Entrevistado 6)

Quanto aos empregados mais antigos, os participantes do estudo acreditavam que não eram mais tão dinâmicos em razão de já estarem perto de se aposentar e sim mais acomodados. Além disso, para o entrevistado 3, o perfil de empregado padrão da Empresa $\mathrm{X}$ era aquele que não resolve, passa o problema adiante.

\section{e.4)Acomodado}

“O empregado padrão digamos, assim, hoje é o empregado antigo, que é o cara perto de se aposentar, trinta anos de empresa, cinqüenta e tantos de idade, entendeu? Aquele pessoal que deu... Que já deu o que tinha que dar para empresa. Estão naquela fase mais de auxilio; não pegando pra si grandes projetos, os grandes desafios e estão só mantendo a linha até eles poderem se aposentar. Então, esse que acaba sendo o empregado padrão. Por quê? Porque era pra ser, digamos assim, o maior efetivo da Empresa X e agora não é mais, né?! Que agora os mais novos são o maior efetivo, mas os mais novos, não tão novos assim como a gente, de certa forma acabam pegando um pouco desse vício, né?!" (Entrevistado 3)

“(...) eu vejo assim que talvez, as pessoas que estejam chegando agora na companhia tenham um maior gás, né?! Tenham uma vontade de crescer maior do que aquelas pessoas que são mais antigas. Exatamente, por essa cultura do sistema de conseqüências, na qual as pessoas já fazem aquilo há anos e nada acontece e tal. E as pessoas que estão chegando novas estão ganhando oportunidades, né?! Então, tem a geração Y que faz as coisas..." (Entrevistado 15) 
"Você acaba não se tornando um empregado padrão, né?! Aquele empregado que só passa o problema adiante, né?!" (Entrevistado 3)

\section{e.5) Avesso às Mudanças}

Foi destacada a questão de resistência à mudança, especialmente por parte daqueles que já estão há mais tempo na Empresa e que preferem manter o status quo.

“(...) Mas, por outro lado, eu vejo aqui que há muita resistência à mudança. Quando você demonstra muita criatividade, nem sempre você é bem visto. E eu quando trabalhei na área de contratação de serviço, eu já ouvi muito de várias pessoas lá, né?! A seguinte frase: aqui sempre foi feito assim. Estou aqui há 25, 30 anos e está bom assim e vamos continuar fazendo assim. Para que mudar, para que pensar de outra forma, sempre deu certo assim. Então, era uma forma de coibir. Exatamente, coibir o empreendedorismo, a inovação, a criatividade. Eu vejo que muita gente aqui tem aversão a mudanças e a mudança é necessária. Não tem jeito. Quer eu queira, quer não. Pronto. Então, tem uma dificuldade grande na adaptação a mudanças aqui dentro. Uma boa parte da empresa tem." (Entrevistado 9) .

Alguns, por outro lado, entendem que não existe uniformidade no comportamento de um empregado da Empresa X, fazendo-nos acreditar que o comprometimento ou não de um empregado está relacionado com as suas características individuais e não com os valores organizacionais.

Para Chatman (1991), o alinhamento indivíduo-organização ocorre mediante uma combinação entre valores individuais e organizacionais. E esse alinhamento influencia o comportamento dos empregados. Quanto mais alinhados à organização, mais comprometidos.

Por outro lado, para Kabanoff e Daly (2002), é importante essa diferenciação, pois os valores organizacionais são aqueles compartilhados e, em alguns casos, podem refletir as práticas organizacionais e, em outros casos, refletem o que as pessoas efetivamente acreditam que a sua organização é verdadeiramente, o que gostariam que a organização fosse ou o que gostariam que os acionistas acreditassem que a organização poderia ser.

"Não concordo muito com esse conceito de empregado padrão, não. Eu acho que em toda a equipe você tem pessoas de níveis 
diferentes e de comprometimento, envolvimentos e com contribuições diferentes." (Entrevistado 15)

"Depende muito da pessoa. É muito relativo. Você pode ver empregados assim se dedicando ao extremo e tal, vestindo a camisa e tem outros que não estão ligando. Então, cumprem o horário das $8 \mathrm{~h}$ às $17 \mathrm{~h}$, pegam a bolsa e vão embora, estão preocupados com outras coisas. E tem gente que: ah, não. Tem filho, está dando prioridade ao filho e não quer ficar se dedicando à empresa." (Entrevistado 13)

"Não, eu vou dizer assim para você: não vejo o petroleiro tendo que agir de forma diferente de um executivo de outra empresa." (Entrevistado 8)

"Eu acho que as pessoas têm que fazer a sua tarefa com responsabilidade, cumprir o horário, aceitar as normas, enfim, se necessário for ficar depois... Enfim, cumprir os prazos, fazer seu trabalho com responsabilidade, mas eu acho que isso não é padrão Empresa X. Isso é padrão de qualquer empresa." (Entrevistado 7)

"Pra mim, ele é igual a qualquer empregado, de qualquer lugar. Tem que ser uma pessoa consciente das responsabilidades dele; tem que ser uma pessoa dedicada ao trabalho; tem que ser uma pessoa que vista a camisa assim, mas não precisa ter esse negócio de petróleo correndo na veia." (Entrevistado 11)

\section{e.6) Empregado Novo x Empregado Antigo}

A diferença entre os perfis de empregados também foi destacada por alguns entrevistados - de um lado os antigos e do outro os mais novos.

"Eu acho que já teve. Era aquele empregado orgulhoso. Aquele que entrava na Empresa $X$ sem ter qualquer outro tipo de experiência, sem ter noção da realidade fora da Empresa $X$, que tinha umas exigências de coisas de que no mundo real não fazem o menor sentido, né?! Mas de um empregado que tem de tudo, né?! Mas assim, de um empregado que se comprometido. O novo dá o sangue, mas ele dá o sangue para satisfação pessoal dele, para o desenvolvimento da carreira dele, para promoção dele, né, até para se sentir contribuindo para a empresa onde ele trabalha." (Entrevistado 16)

“(...) O empregado da Empresa X, principalmente, os mais antigos. Eu já tinha falado um pouco disso aqui. Esse lance do cara vestir mesmo a camisa da empresa, ter esse orgulho de trabalhar na Empresa X, né?! Ter um verdadeiro amor pela empresa mesmo. Isso realmente acontece, principalmente, nos caras que estão com os seus vinte anos de empresa para cima. 
Você vê que os caras realmente, os caras amam esse negócio aqui. Eu acho que os mais novos, isso vai ter que ser conquistado ainda, né?! A empresa vai ter que conquistar isso." (Entrevistado 12)

"Eu acho que existem dois perfis. E que existe um perfil mais acomodado com as coisas, que acha que o status quo ele demora ou ele deve ser esse por um longo tempo e outros que têm uma ansiedade maior por mudanças, que é nosso caso. E eu acho que essa necessidade de mudança, ela existe e ela é latente. Pode ser que essa pressão não venha de fora. Hoje, ela vem muito mais de dentro porque quase a metade da força de trabalho agora é nova, recente de casa... Então isso é um choque, existe esse choque a força de conservação é maior que é de transformação. (...) Existe aquele que está mais perto da aposentaria e não vê essa necessidade como algo urgente. $\mathrm{E}$ outros que dizem assim: "A Empresa X ela não é uma estatal. Ela precisa ser mercado. "Ela tem partes interessadas". Isso é muito difícil. Eu acho, no meu entender, que para a pessoa mais antiga de casa é muito mais difícil aprender isso: entender que uma empresa vive em função de todos os requisitos externos que a circundam. "(Entrevistado 5)

"O que eu percebo que existe é uma diferença entre os empregados. Nos mais antigos, eu percebo que existe esse sangue que não é só sangue, que existe petróleo na veia. E nos mais novos, não existe isso. Mais uma vez eu falo, fazer o trabalho com responsabilidade existe, mas dá, assim, o sangue pela empresa, não." (Entrevistado 7)

"Vou falar até mais alto. Eu consigo ver um pouco porque o empregado mais antigo tem mais a sensação de um feito extraordinário de estar na Empresa $\mathrm{X}$ do que um empregado mais novo. Acho que o empregado mais novo, ele vê a empresa com mais uma oportunidade de ganhar dinheiro. $\mathrm{O}$ empregado mais antigo ele não vê só isso. O empregado mais antigo, na sua maioria, ele vê a empresa que ele ajudou a construir." (Entrevistado 8)

"A tal, que se falava da cultura dos antigos com os novos, ela é real." (Entrevistado 10)

\section{e.7) Não vê diferença entre novos e antigos}

Em contrapartida, muitos desmistificaram o entendimento de que os novos trabalham mais do que o pessoal que já está há mais tempo na Companhia. 
“É... Hoje, eu vejo gente que quer e gente que não quer. Eu não vejo entre novos e velhos. Eu vejo, assim, pessoas mais encostadas, novos às vezes. Novos, menos. Novos nem tanto, até porque o movimento parece que é maior. Mas vejo, assim, aquele que é muito antigo que está desmotivado por algum motivo ou ele se auto desmotiva ou porque ele está mal colocado, entendeu? Aqui eu tenho alguns exemplos, assim, dessa vivência de mal colocado, mal aproveitado. Lá na RELAM tinha gente que fazia 20 anos a mesma coisa. Entende? Não se abria para o novo. Então, não entende esse tipo de cultura. E existe gente que quer fazer, entendeu? Conheci pessoas mais velhas mesmo, mas que tem uma visão mais antenada no que está acontecendo, integrada, entendeu? Não é o meu. É o que é nosso, o que o meu trabalho interfere no seu, entendeu?" (Entrevistado 10)

"Depois que você entra aqui na Empresa $X$, você começa a ver que tem algumas culturas que te incomodam, né?! Vou dar um exemplo, né?!Tem aquela pessoa na equipe que não faz nada. Tem umas pessoas que são indicadas de fulano e estão ali e ninguém mexe com elas. Então, assim, esse tipo de coisa é problema." (Entrevistado 15)

"Olha, eu vejo muito antigo se dando muito mais do que o novo. Tem gente que na hora de se aposentar não está nem aí e o antigo está ralando. E tem gerência onde o antigo rala muito mais do que o novo, entendeu? Então, assim, está com previsão de aposentadoria agora e o novo está lá: "consegui meu emprego estável, um salário bom, não sei o que...”. (Entrevistado 13)

\section{e.8) Menos pressionado do que o empregado de empresas privadas}

Em razão de alguns terem tido experiência anterior em empresas privavas, conseguiram perceber que o ritmo na Empresa $X$ é diferente. Perceberam que a cultura se aproxima da realidade do estereótipo do serviço público, em que as coisas não precisam ser para ontem, existe pouca pressão, e tudo poderá ser corrigido se for feito de forma errada.

"O tempo, isso é uma coisa bem diferente. O tempo Empresa X é muito diferente do tempo numa empresa privada comum, como a empresa onde eu trabalhei. Que era tudo pra ontem sem erro, né?! Aqui não, você faz tudo pra amanhã e pode errar a vontade que isso não tem nenhum...É eterno aprendizado e acho que isso a empresa podia melhorar com relação a essa cultura do empregado da Empresa X, entendeu?" (Entrevistado 3) 
"Porque eu vim de uma empresa que era um Banco, que é público também, mas que era outro perfil. É lucro, é cobrança, é venda, é concorrência... Então, eu entrei com um pique, querendo fazer tudo rápido e tudo para ontem. Menos pressão. Ele é mais tranqüilo, ele tem mais certeza do emprego dele, da estabilidade... Eu percebo isso. Eu acho que perfil...Ah, eu me considero. Querendo ou não, a gente está incluído naquele contexto e... Todos são assim. Os mais antigos, os mais novos, os mais experientes tem aquele comportamento e a gente vai meio que indo na onda. Quando eu cheguei, estava destoando completamente." (Entrevistado 14)

"É um meio termo. O cara está preocupado em agir corretamente, entendeu? Eu acho que não existe esse grau de cobrança como em uma empresa privada. Eu acho que a área técnica, quem está com a mão na massa, é muito mais pressionada. A parte de engenharia que também cuida de obra. Eles têm muito mais que lidar com o dia-a-dia do que está acontecendo do que eu, que estou por trás. Sou mais uma atividade de apoio. Não sou uma atividade fim, vamos dizer assim.” (Entrevistado 6)

\subsection{3.}

\section{Período entre a Alocação na Área até a data da entrevista}

\section{Categoria 1: 0 que te segura até hoje na Companhia?}

Os entrevistados foram questionados sobre o real motivo que os mantém ainda motivados a trabalhar na Empresa X. Entre as principais causas está a questão financeira e o status/glamour de se trabalhar em uma Empresa tão reconhecida dentro e fora do país. Isso faz-nos inferir que se trata da ratificação quanto ao Valor: Sentir orgulho de trabalhar na Empresa X.

\section{a) Dinheiro/ Status}

“Um: salário. Mas é por aí assim... É tipo, status de estar na companhia, de ser uma empregada da Empresa X. É, mas não é status assim de: “Oh, meu Deus!'É porque eu acho legal dizer: "Ah, você trabalha onde? "Eu trabalho na Empresa X. O glamour assim.” (Entrevistado 1)

"No começo, sei lá, nos primeiros três, quatro anos, eu gostava muito do trabalho que eu fazia. Eu gostava bastante, além de ter orgulho de trabalhar na Empresa X que é uma empresa do Brasil. Todo mundo conhece a Empresa X no Brasil e no mundo. Então, a empresa é conhecida mundialmente como uma grande empresa e também pelo trabalho que eu gostava bastante. Mas atualmente, 
eu vou ser sincero contigo, eu me acomodei aqui por causa da questão do salário. Razoavelmente bom, para os padrões brasileiros, né?! Tem a famosa estabilidade que a gente tem aqui, entendeu? E a perspectiva também que a gente pode se movimentar na empresa sem mudar de empresa, né?! Pode buscar novos horizontes, claro que aquilo também de cultura, no RH não é tão fácil assim você conseguir mudar de área, mas teoricamente..." (Entrevistado 3).

"Olha, pelo dinheiro. Sim, porque a gente tem a partir do momento que a gente passa na companhia a gente assume um status social. A gente tem uma condição financeira para adquirir, para consumir coisas, né?! Que a gente não tinha antes...O salário que eu ganho aqui, hoje, na Empresa $\mathrm{X}$, me deixa confortável a não ter que procurar outro emprego" (Entrevistado 4).

"Mas olha, estou muito bem. Assim, com o salário que eu estou ganhando em relação às horas que eu trabalho. Isso me dá oportunidade suficiente para eu ter qualidade de vida e pensar em negócios por fora" (Entrevistado 8).

"Salário, sem dúvida, hoje como gerente. É um salário muito legal" (Entrevistado 16).

O entrevistado 2 coloca a permanência dele na Companhia relacionada à questão da necessidade. Nessa mesma linha, o entrevistado 10 realça o trabalho como seu sustento.

"Não. É isso, assim, ó, eu hoje tenho isso aqui como meu sustento, pela minha realidade. Você sabe. É o meu sustento" (Entrevistado 10).

\section{b) Acomodação}

Outros argumentam que estão acomodados com a situação.

"Preguiça de ter procurado outra coisa melhor: acomodação" (Entrevistado 5).

"Basicamente, eu posso dizer assim: o salário. É o salário até certo ponto, né?! Porque agora eu acho que estou acomodada assim. (...) Basicamente, o salário e na esperança de que eu vou conseguir evoluir e tal (Entrevistado 6).

“(...) Hoje, eu posso falar que me acomodei” (Entrevistado 14).

\section{c) Estabilidade/ Segurança}


"O mais forte eu acho que é a estabilidade. É assim... A estabilidade. Acho que o salário melhorou." (Entrevistado 6).

"O que me fez ficar e permanece fazendo que eu queira ficar é essa parte desse compromisso meu com a empresa e da empresa comigo. Dessa segurança que ela me transmite e que eu quero transmitir pra ela também. De que eu estou no mesmo barco e eu quero fazer o meu melhor" (Entrevistado 9).

\section{d) Fazer o que gosta/ Desafio do trabalho}

Alguns relatam que o trabalho os desafia e que, portanto, conseguem se sentir mais satisfeitos.

"Porque eu me sinto desafiada como eu gostava de me sentir." (Entrevistado 11)

"Eu trabalho com que gosto. Me sinto valorizada. Eu acho que tenho autonomia, tenho reconhecimento..." (Entrevistado 15)

"Satisfação profissional. Gosto. Não amo que eu faço." (Entrevistado 16)

\section{e) Conjunto de Fatores}

“A Empresa X, para mim, é um bom emprego. Eu acho que a gente tem uma boa remuneração. Eu acho que a gente tem um lugar bacana de se trabalhar. Você tem um horizonte grande de atuação. Você tem condições de trabalhar. Você tem recursos. Você quer tocar... Sei lá. Você pode desenvolver projetos, que a empresa vai ter grana para bancar. Você tem recursos físicos lá disponíveis...Eu tenho autonomia para trabalhar. Eu tenho bastante autonomia para trabalhar..."(Entrevistado 12)

“Cara, é um pouco de tudo. É a estabilidade, é a questão salarial que hoje em dia [...] Lá fora nunca estaria ganhando o que eu estou ganhando aqui, hoje. É a questão também de gostar do que faço" (Entrevistado 13).

Com base nas declarações acima, foi possível observar que os indivíduos são motivados tanto por fatores subjetivos (qualidade de vida, preocupação com pessoas, bom ambiente) e não apenas por fatores objetivos (salários, benefícios), 
conforme destacado nos estudos de Heslin (2003), Baruch (2004) e Lounsbury et al. (2004).

\section{Categoria 2: Identificação com os Valores e Comportamentos}

Nesta etapa, os entrevistados foram questionados sobre os valores explícitos, presentes no discurso da Companhia.

A importância dos valores para uma organização é latente, pois eles são a base para a geração de comportamentos que se adéquam às necessidades do grupo (KLENKE, 2005).

Ressalta-se que quanto mais alinhados à organização, especialmente com relação a valores, maior o nível de atração e menor a possibilidade de conflito (ELFENBEIN; O’REILLY, 2007)

Quando questionados se o empregado-padrão da Empresa $\mathrm{X}$ deveria se comportar seguindo os valores presentes no discurso da Companhia, foi possível identificar que a maioria dos entrevistados entendeu que sim, conforme tabela a seguir:

Quadro 2 - Valores e Comportamentos da Empresa X

\begin{tabular}{|c|c|c|c|c|c|c|c|c|c|c|c|c|c|c|c|c|}
\hline \multirow{2}{*}{ Valores/Comportamentos da Empresa $\mathrm{X}$} & \multicolumn{16}{|c|}{ Entrevistados } \\
\hline & 1 & 2 & 3 & 4 & 5 & 6 & 7 & 8 & 9 & 10 & 11 & 12 & 13 & 14 & 15 & 16 \\
\hline Desenvolvimento Sustentável & Não & Não & Sim & Sim & Sim & Sim & Sim & Sim & Sim & Sim & Sim & Sim & Sim & Sim & Não & Sim \\
\hline Respeito à Vida & Sim & Sim & Sim & Sim & Sim & Sim & Sim & Sim & Sim & Sim & Sim & Sim & Sim & Sim & Não & Sim \\
\hline Diversidade Humana e Cultural & Sim & Sim & Sim & Sim & Sim & Sim & Sim & Sim & Sim & Sim & Sim & Sim & Sim & Sim & Não & Sim \\
\hline Ética e Transparência & Sim & Sim & Sim & Sim & Sim & Sim & Sim & Sim & Sim & Sim & Sim & Sim & Sim & Sim & Sim & Sim \\
\hline Integração & Sim & Sim & Não & Sim & Sim & Sim & Sim & Sim & Sim & Sim & Sim & Sim & Sim & Sim & Sim & Sim \\
\hline Resultados & Sim & Sim & Não & Sim & Sim & Sim & Sim & Sim & Sim & Sim & Sim & Sim & Sim & Sim & Sim & Sim \\
\hline Prontidão para Mudanças & Sim & Sim & Não & Sim & Sim & Sim & Sim & Sim & Não & Sim & Sim & Sim & Sim & Sim & Sim & Sim \\
\hline Empreendedorismo e Inovação & Sim & Sim & Não & Não/Sim & Sim & Sim & Sim & Não & Sim & Não & Não & Sim & Sim & Não & Não/Sim & Sim \\
\hline Pessoas & Sim & Sim & Sim & Sim & Sim & Sim & Sim & Sim & Sim & Sim & Sim & Sim & Sim & Sim & Sim & Sim \\
\hline Orgulho & Sim & Sim & Sim & Sim & Sim & Sim & Sim & $\begin{array}{c}\text { Às } \\
\text { vezes }\end{array}$ & Sim & Sim & Sim & Sim & Sim & Sim & Não & Sim \\
\hline Seguir o Exemplo dos Líderes & Sim & Sim & Sim & Não & Sim & Não & Não & Sim & Sim & Não & Sim & Sim & Sim & Sim & Sim & Não \\
\hline
\end{tabular}

Fonte: Autoria própria, (2012)

Os entrevistados demonstraram conhecer tais valores e reconheceram que, de um modo geral, é esperado que os empregados da Companhia se comportem com base nesses preceitos.

"Olha só, são diretrizes da empresa. A gente tem padrões. A gente tem vários instrumentos de gestão aí. Aliás, nos padrões e no código de ética essas coisas todas estão escritas. São escritas e são diretrizes. É esperado como para qualquer lei, em qualquer país, a Constituição 
existe... Qualquer empregado não tem que dizer que não conhece, que fez o crime porque desconhece a Constituição. Com relação aos valores, a empresa sempre faz isso, ela realmente faz, dissemina." (Entrevistado 5)

Vale destacar que a partir do momento em que a cultura auxilia representa um sistema de valores compartilhados, o alinhamento cultural passa a ser uma força integrativa que mantém a organização unida.

Por outro lado, o que é esperado nem sempre é o que realmente acontece ou o que realmente os empregados gostariam que acontecesse.

Entrevistador: Você se sente identificado com a companhia? Com a cultura, Valores e Normas?

Entrevistado: "Com alguns valores, sim. Os valores que estão escritos. Não os práticos. É. Aquilo que se propõe e aquilo que é feito, né?! Aquilo que é feito, não. Que se propõe, sim." (Entrevistado 5)

Nesse sentido, Oliveira e Tamayo (2004) destacam que os valores pessoais e organizacionais constituem dois sistemas consolidados que podem entrar em confronto em razão da possibilidade de haver conflito entre os interesses individuais e os organizacionais.

"Posso concordar em grande parte com esses valores e com essa cultura da Empresa X, mas eu não sei se eu consigo me ver em todos." (Entrevistado 2)

\section{a) Desenvolvimento Sustentável}

Com relação ao Vetor: Desenvolvimento Sustentável, 13 dos 16 entrevistados reconhecerem que a Companhia se esforça para que seus empregados absorvam esse valor. No entanto, as percepções foram influenciadas pela experiência que cada um tem do local onde trabalha, demonstrando que, em razão do tamanho da Empresa, a implementação dos conceitos na prática nem sempre é uniforme.

"Então, olha só! É aquela coisa, né?! Nunca saí aqui do RH. Então, a única visão que eu tenho é daqui. Eu acho que aqui não se aplica." (Entrevistado 1)

"Pois é... Eu tenho dificuldade de ver o desenvolvimento sustentável... Porque, assim, como é que a gente poderia 
contribuir para um desenvolvimento sustentável na Empresa X se a gente está falando de uma empresa que trabalha com óleo? É o que? Economia de papel? Não sei. Eu não consigo ver." (Entrevistado 2)

"Por exemplo, a companhia tem muita coisa de patrocínio, né?! Patrocínio e convênio e tal. Ai sai muito no jornal, sai na matéria e tal. Acho que todo mundo sabe que a Empresa $X$ apóia essas iniciativas. Certo? Agora o que é esperado disso no dia-a-dia das pessoas? Acho que isso não está claro, entendeu?" (Entrevistado 15)

Outros argumentaram que são os valores individuais que definem o comportamento, o que reforça o entendimento de Cultura como uma característica da organização e não dos seus indivíduos (TICHY, 1992).

"Eu acho que é esperado sim, mas vai de cada um. Eu creio muito nisso. É uma questão de valor pessoal mesmo. É você estar preocupado com o futuro. A Empresa $\mathrm{X}$ te dá os subsídios para você pensar dessa forma sim, mas vai de cada um..." (Entrevistado 8)

\section{b) Respeito à Vida}

Ao se tratar as questões de Saúde, Segurança e Meio Ambiente, com exceção de um entrevistado, o restante reconheceu o valor Respeito à Vida. As orientações da Companhia são tão fortes nesse sentido que o empregado transfere o aprendizado para a sua vida fora da Empresa.

"É a Empresa X acaba fazendo... Eu vou usar um termo aqui uma higiene mental ...É, como algumas religiões costumam fazer, né?! Para essas questões, eu acho válido. Eu acho que eu fico mais preocupado em usar o cinto de segurança por trabalhar na Empresa $X$ do que qualquer outra pessoa. Que tanto você ouve isso, você faz isso acontecer. Eu estou andando na rua falando no celular... Estou distraído com o celular, eu sei que eu preciso falar no celular, mas ao mesmo tempo... "Eu não devia dar mole para o bandido, de repente alguém está me filmando, está filmando o celular". Eu tenho que evitar o risco. Assim, não está legal. Eu sei disso porque a Empresa X me ensinou isso." (Entrevistado 8)

"E, eu até brinco. Falo que é meio uma lavagem cerebral nesse ponto ai. De tanto que eles batem nessa tecla. De tudo! De meio 
ambiente. De reciclagem. De respeito social. Eu me vejo, às vezes, fazendo isso em casa, na rua, sem está consciente." (Entrevistado 14)

\section{c) Diversidade humana e cultural}

Com base na percepção de 15 entrevistados, as ações da Companhia convergem para o compartilhamento desse valor.

Entrevistador: Você acha que é esperado do empregado padrão da Empresa $X$ que ele trabalhe seguindo os preceitos de Diversidade Humana e Cultural: (respeito às diferenças, não discriminação e igualdade de oportunidades)?

Sim. (Entrevistado 16)

"Quando você fala de igualdade e oportunidades, nesse caso aí, você tá falando assim, né, do branco, do negro. Eu acho que não tem preconceito." (Entrevistado 11).

\section{d) Transparência e Ética}

Os entrevistados foram unânimes ao considerar os Vetores: Transparência e Ética como valores compartilhados por eles, e que produzem um senso de direção comum, um modelo desejável de comportamento, ainda que, em alguns casos, haja críticas quanto à rotina da Empresa.

"Sim... Passam isso para a gente, no entanto no meu trabalho, o que é mais aplicado é a transparência e a ética." (Entrevistado 7)

"É. A gente absorve muito transparência e ética dos nossos gerentes. Com bons gerentes, a gente segue o exemplo." (Entrevistado 8)

"Eu acho que transparência a Companhia tenta fazer, né?! Mas o problema é que, assim, a gente fica sabendo do plano de negócio, das fofocas e das mudanças da Companhia pelo jornal. A gente está nesse grande processo de mudança, pelo menos, mudança na área onde trabalho, na qual surgem muitas gerências e desestrutura tudo, mas enquanto não formaliza, nada é divulgado. Enquanto isso, a rádio corredor já sabe de tudo." (Entrevistado 15)

\section{e) Trabalhar em Equipe}


Os entrevistados foram questionados se é esperado do empregado padrão da Empresa $\mathrm{X}$ que ele trabalhe em equipe. A integração entre equipes, áreas e unidades é um valor desejável pela Companhia. Quase a totalidade dos entrevistados concordou com esse vetor, com exceção de um que ressaltou que, apesar de haver um sistema específico para medir o desempenho dos empregados, essa medição não contempla tarefas/atividades realizadas em equipe, apenas tarefas individuais.

"Não me lembro de ter ouvido isso. Nem nenhum comentário sobre isso diretamente. Até porque nossa avaliação, por exemplo, é individual." (Entrevistado 3)

Ainda que a concordância com esse vetor tenha sido quase unânime, algumas ressalvas foram feitas, especialmente quando comparado à realidade da Companhia:

"Mas na prática eu vejo que tem hora que não funciona, principalmente, com esses empregados mais antigos...(...) Muita dificuldade em trabalhar em equipe, de expor as idéias do que eles pensam, de concordar com a opinião dos outros. Nas reuniões, assim, eles não participam, não trazem idéias. Eles estão ali só para compor ...” (Entrevistado 14)

\section{f) Atingir Resultados}

Segundo literatura a respeito, as organizações expressam seus valores ideologicamente ou por meio de suas ações concretas, sendo que os valores definidos pela ideologia não são necessariamente aqueles que efetivamente orientam o comportamento no dia-a-dia (VAN REKOM; VAN RIEL; WIRENGA, 2006).

Ainda que 15 dos entrevistados reconheçam que a Companhia se preocupa com resultados, questionaram a sua aplicação na prática.

"Aqui falasse muito nisso, ultimamente, só que não vejo muito na prática. Sinceramente, aqui no $\mathrm{RH}$, eu acho que isso fica muito na fala, mas na prática quando a gente... O que eu acho que onde a gente sente mais essa questão é no GD, na prática não se mostra, assim, tão preocupado com relação a resultados." (Entrevistado 3) 
"Esperado é, mas, às vezes, eu vejo que não existe uma... Apesar de você atingir o resultado, né?! É muito subjetivo isso... Quando você vai ser avaliado." (Entrevistado 6)

"É, eu acho que a empresa ai, por ela ser uma empresa muito rica, né?! Rica em todos os sentidos, não só apenas de dinheiro... Mas em todos os sentidos, até em capital intelectual, inclusive, né?! É, eu acho que ela relaxa um pouco nessa parte de resultados. Então, eu tenho um resultado aqui, mas, de repente, se eu não for atingir, eu modifico um pouquinho lá a minha meta. $\mathrm{Ai}$, eu atinjo, então. Quase atinge, tá bom. Esse ano não deu, talvez ano que vem dê. Não estou dizendo assim que... É... Não tem importância isso. Tem, mas eu acho que deveria ser dada mais importância, né?!” (Entrevistado 9)

"Olha, a empresa não conseguiu desenvolver uma metodologia para fazer isso. Não conseguiu. O GD não faz isso. Mas eu acho que é esperado que a gente atinja resultado sim." (Entrevistado 12)

"Eu acho que é esperado que a gente atinja resultados sim, mas a forma de medir que, às vezes, não é a mais adequada." (Entrevistado 13)

\section{g) Prontidão para mudanças}

O Valor prontidão para mudanças, pela maioria das respostas, foi validado como presente na Cultura da Empresa X.

Entrevistador: Você acha que é esperado do empregado padrão que ele esteja pronto para mudanças?

"Sim, sim. Mudança acontece o tempo todo nesta empresa." (Entrevistado 5)

"É até porque é um ambiente em constantes mudanças essa nossa empresa." (Entrevistado 14)

"Se a gente for ver pelo discurso dos gerentes dessas épocas, né?! Eles deixaram bastante claro em vários momentos isso, né?! Olha, nós estamos sempre mudando. Isso não vai ser só a primeira vez que você vai passar por isso. Então... eu, por exemplo, passei por muitos momentos de mudança aqui e eu tinha que estar preparado para não desmerecer o meu trabalho. Para não ficar sem um trabalho que fosse, que eu considerasse ..., que agregasse valor ao que eu tava fazendo, né?! Para não ser é... colocado em uma função que não fosse apenas aquela coisa de 
que eu falei. A pessoa está lá insatisfeita no trabalho, sem fazer o que gosta e mesmo assim ela continua lá.” (Entrevistado 4).

Para Shein (1989), a cultura é composta de valores patrocinados que só são internalizados, ou seja, tidos como crenças após um "teste" dos mesmos. Isso quer dizer que não basta o valor ser dito, ele deve ser mostrar eficaz. Para 2 dos 16 entrevistados, não é esperado do empregado padrão da Empresa X que ele esteja preparado para mudanças.

"Eu gostaria que fosse. Eu acho até que deveria, mas por essa parte da cultura da empresa ainda está muito resistente, né?! Ainda está muito entre aspas assim: com foco antigo. Aí, acaba que não é esperado porque o padrão da Empresa $\mathrm{X}$ é: vamos deixar assim e tal. Se mudar um pouquinho está bom, mas não vamos mudar muito, não, ta? Muda, mas não muito (...) Tudo certinho. Minhas atividades, as mesmas de preferência. Se quiser até pode trocar uma ou outra, mas não mexe muito aqui, não." (Entrevistado 9)

\section{h) Empreendedorismo e Inovação:}

Os entrevistados foram questionados se é esperado do empregado padrão da Empresa X que ele seja um empreendedor. Mesmo que 56\% dos entrevistados concordem com essa afirmação, ainda há controvérsias sobre o tema.

"Eu vou dizer que sim, mas eu não acho que isso esteja na cultura da empresa. Pode ser em algumas áreas." (Entrevistado 5)

Entrevistador: Você acha que é esperado do empregado que ele seja empreendedor?

"Não." (Entrevistado 15)

"Sim." (Entrevistado 16)

Um dos entrevistados destacou que o vetor Inovação é pouco reconhecido nas práticas da Companhia, restringindo-se mais à área técnica.

“(...) A própria cultura da inovação. Pessoal fala muito, mas você vê pouco s prática da inovação.” (Entrevistado 10)

"Mas... Eu não sei. Eu acho que o reconhecimento da companhia é muito pouco em relação a isso, né?! Nós temos aqueles prêmios... Tem um prêmio inclusive para os inventores, né?! Mas ele fica muito restrito a área técnica, né?!” (Entrevistado 4) 
Até mesmo em razão do tipo de trabalho que se executa, a orientação da Empresa $\mathrm{X}$ pode ser considerada contraditória ao limitar a prática da inovação no dia a dia.

"Muito pelo contrario, eles sempre falam que tem que seguir as regras legais e tal. Que a gente não pode ser tão inovador, porque existem órgãos fiscalizadores etc.” (Entrevistado 7)

\section{i) Pessoas: Investir no Empregado e no seu Desenvolvimento}

De acordo com os entrevistados, a Empresa X estimula o treinamento, o aprimoramento e o desenvolvimento de competências. Já que alguns esperavam que isso acontecesse, mesmo antes de entrar na Companhia, o treinamento passa a representar uma contra-partida da Empresa para fortalecer a sua relação com o empregado.

"Ele espera. Acho que foi uma das grandes expectativas que eu vejo, que eu tinha e que eu vejo que as outras pessoas tem é nesse lance. Que a Empresa X tem essa imagem. Uma empresa que investe no empregado, capacita ..." (Entrevistado 12)

"Sim. Eu acho que faz parte do incentivo ao empregado padrão, né?! Se a gente está falando nisso ...Se ela não fizer isso... faz parte da expectativa de uma empresa que quer manter o empregado padrão." (Entrevistado 4)

"Não me faltou até hoje treinamento para me ajudar." (Entrevistado 5)

Entrevistador: E você acha que os empregados, em geral, esperam que a Empresa $\mathrm{X}$ invista neles?

"Ah, sim! As pessoas acham que a Empresa $\mathrm{X}$ tem obrigação legal, né,!?” (Entrevistado 7)

\section{j) Orgulho de ser Empresa $X$}

Desde a época da Ambientação, sentir orgulho da empresa é um dos valores patrocinados por ela. No caso deste vetor, podemos inferir que o processo de socialização foi bem aplicado e absorvido pelos empregados, contribuindo para assimilação da Cultura. 
Entrevistador: Você acha que é esperado do empregado padrão que ele sinta orgulho de ser Empresa X?

"Sim." (Entrevistado 16)

"Eu acho que é esperado. Eu acho que isso é uma das coisas que se destaca assim, né?! Como se fala das pessoas que trabalham aqui ou das próprias pessoas que trabalham aqui que vão falar para os mais novos, que estão entrando, disso, né?! Do orgulho..." (Entrevistado 12)

Em contrapartida, alguns ainda questionam as ações da Companhia na prática com relação a esse Vetor.

"Certeza. Eu acho que, em alguns momentos, sim e, em outros, nem tanto. Em alguns momentos, quando ela faz uma campanha que ela conseguiu ser auto suficiente, eu acho que foi um momento que ela quis mostrar que você precisa ter esse orgulho, certo. Em outros momentos quando ela faz algumas práticas de... Por exemplo, passou muito tempo patrocinando o Flamengo. Não está preocupada ali em você ter orgulho disso, porque quem não é flamenguista achava horrível. Eu achava horrível ver o nome da minha empresa em um time para o qual eu não torço. Ela estava preocupada ali com o retorno financeiro. Ali ela não estava preocupada com orgulho." (Entrevistado 8)

“Não me sinto cobrada disso, não.” (Entrevistado 15)

\section{k) Comportamento: Exemplo pela Liderança:}

Um dos comportamentos desejados pela Empresa $\mathrm{X}$ e que está presente no seu discurso é seguir o exemplo de seus líderes. Com relação a esse tema, onze entrevistados compartilham desse valor enquanto que os demais criticam a aplicabilidade do conceito na prática.

“(...) porque assim... esperado da companhia é claro que é sim. Porque, para companhia, os líderes que ela... Afinal, de contas, se o cara está lá, o cara é bom, né?! O cara é competente, o cara é um líder a ser seguido. Só que a gente vê, assim, que na vida real, não é nada disso. Que muitas vezes, um peão é muito melhor que o que está lá mandando nele, né?! Então, às vezes, é até bom que não siga o exemplo.” (Entrevistado 1)

"Eu acho que sim. Acho que a vontade de todo gerente aqui, de todo superior imediato, que a equipe siga...Eu vejo assim pela 
liderança atual. Eu acho que ela sempre tenta assim dar o exemplo ..." (Entrevistado 13)

“A empresa espera isso. Se o cara está lá há 50.000 anos daquele jeito, é porque algum valor ele tem." (Entrevistado 14)

"Eu acredito que sim, né?! Se os líderes estão lá são para gente seguir os seus exemplos." (Entrevistado 2)

“Sim, embora mais do que o necessário." (Entrevistado 5)

"Não, não. Esse valor não é passado para a gente. Sempre me falaram que eu tinha que dar o exemplo." (Entrevistado 6)

"Não, sinceramente, eu não vejo isso, não. Até porque, aqui, eu vejo poucos líderes. Os gerentes da Empresa X não são líderes; são chefes." (Entrevistado 7)

Com base nas entrevistas, pode-se inferir que os valores transmitidos pela Companhia foram internalizados pelos empregados. Isso quer dizer que o objetivo principal da socialização de assegurar a continuidade dos valores centrais e normas foi alcançado.

Os entrevistados, em sua maioria, compartilham dos valores explícitos da Companhia, ainda que, na prática, verifiquem que algumas ações diferem do discurso.

Em razão desse compartilhamento, podemos inferir que os empregados se sentem membros-participantes da Empresa X. Há, portanto, um sentimento de pertencimento; eles se identificam, de forma geral, com os valores transmitidos, ainda que com algumas ressalvas.

Podemos dizer, dessa forma, que a socialização contribuiu para o alinhamento cultural na medida em que houve uma assimilação da cultura e dos valores organizacionais.

\section{Categoria 3: Comparação entre o discurso e a prática.}

Os entrevistados foram questionados sobre as dissonâncias entre o que estava presente no discurso oficial da Companhia, na época da socialização e o que realmente eles perceberam na rotina da Empresa durante esses seis anos de trabalho efetivos na área. 
Considerando que a cultura representa um sistema de compartilhamento de valores, o alinhamento cultural passa a ser força que mantém a organização unida.

No caso de decepções nos indivíduos, causadas pelas divergências entre o discurso e a prática da Companhia, perdas de produtividade e motivação no trabalho podem ocorrer.

Um dos temais mais citados pelos entrevistados foi a Mobilidade. A empresa anunciou durante a Ambientação que, por ser uma empresa de grande porte, com muitas possibilidades, seria possível trabalhar em vários lugares/setores. Havia até uma frase padrão utilizada para descrever o sentimento da época: "Na Empresa X, você muda de emprego sem sair da Empresa”.

No entanto, a prática não se confirmou, pois, ainda que haja regras, o poder de decisão está nas mãos dos Gerentes, conforme declarações de alguns dos entrevistados. Novamente, foi possível verificar a presença de características de uma Cultura Hierárquica.

O valor mobilidade é compartilhado pelos empregados, mas não observado nas práticas organizacionais. Verifica-se a existência de uma sub-cultura, por parte dos empregados, que valoriza a mobilidade e critica o excesso de poder concedido aos gerentes.

Nesse caso, podemos inferir que pode ter havido uma perda no alinhamento indivíduo-organização já que, segundo Cable and Judge (1996), as pessoas preferem trabalhar em organizações que reflitam seus valores pessoais.

\section{a) Mobilidade}

"Sim. Você muda de empresa sem mudar de emprego. Tem grande mobilidade. A Empresa X está no Brasil inteiro e nada é para sempre. Você não tem que cumprir um tempo mínimo no cargo. O discurso?! $\mathrm{Na}$ prática é completamente diferente. Porque depende de um monte de coisas. Depende de ter a vaga onde você quer. Depende de ter uma pessoa para ir para sua vaga. Ninguém te fala que a Empresa $X$ ficou mais de 10 anos sem contratar. Ai quando a pessoa consegue alguém para o cargo, ela segura com unhas e dentes. Ninguém te fala isso. E é o que acontece. Ficou uma lacuna ai de mais de 10 anos sem contratar ninguém. Caiu ali naquele cargo dançou. O problema é seu. (...) Tudo depende do seu gerente. Se você pega uma pessoa carrancuda e que fala: não vou te liberar. Eu preciso de você. Eu 
não tenho ninguém para vir para essa vaga. Acabou". (Entrevistado 14)

"Tem que reconhecer que lá, todos os empregados falavam: "Ah! Essa empresa é maravilhosa! Porque a gente trabalha 30 anos aqui e muda várias vezes de trabalho, mas não muda de emprego. Porque aqui tem muita coisa boa, maravilhosa e etc, mas quando você chega, você vê que não é bem assim. Que é um parto para conseguir sair..." (Entrevistado 1)

"Bom, a primeira coisa que eu vejo aí, que tem conflito entre discurso e a prática, é a questão da mobilidade. Foi dito que a gente teria uma facilidade. Que a Empresa $X$, que cada área da Empresa X é uma empresa. Eu acredito que realmente seja... Não tenho a oportunidade de... Você não precisa mudar de emprego, é só mudar da área. E não é bem assim. Existem regras que não estão colocadas em lugar nenhum. Fica na cabeça de cada um dos gerentes. E você tem que ficar se submetendo as regras, assim, sem saber se elas tão corretas ou não." (Entrevistado 2)

“(...) Que é uma empresa boa, que dá oportunidades, que existem várias Empresas $X$, que você tem mobilidade. Isso não se confirmou. Hoje, eu vejo uma grande falácia, né?! Que você teria um campo aberto, enorme para o seu desenvolvimento profissional. Que a Empresa X são várias empresas em que você tem muitas oportunidades e não é. O gerente aqui se acha dono. Aqui você está vinculado ao cargo. Você não é uma pessoa, você é um cargo." (Entrevistado 5)

"A essa é boa porque é um parto para as pessoas que querem trocar. Não, foi dito isso sim. Que a Empresa X era uma empresa com várias empresas dentro. E que poderia existir essa mobilidade, mas - na pratica - principalmente, se você trabalhar bem, o cara..." (Entrevistado 7)

“A questão da mobilidade dentro do sistema é algo muito ruim. Isso não tem nem como dizer que é razoável. No discurso, eles disseram que era difícil, mas que poderia acontecer. É diferente da prática. É quase impossível e quase não acontece. O empregado entra e, às vezes, é fadado a ficar muito, muito tempo..." (Entrevistado 8)

"Uma coisa que eu não gostei: que disseram que era assim... Se você não se adaptou em alguma coisa, então, é fácil você mudar para outra área. Eu não concordo com isso. Pode até ser em alguns casos, mas pelo o que eu já vivenciei... no meu e de várias pessoas que eu conheço não é bem assim... Eu penso que é porque as pessoas olham para o próprio umbigo, né?! Eu ofereci 
vários benefícios para algumas pessoas, um mestrado, uma pósgraduação e ai... Então, essa pessoa é minha até ela morrer ou eu morrer primeiro. Então, eu acho que não é bem assim. (...) Que a prática está diferente do discurso. A mobilidade dentro da empresa, né?! Muitos gerentes querem amarrar você. Que era: pô, beleza, uma das vantagens de se trabalhar na Empresa $\mathrm{X}$ é que se você tiver na área e por algum motivo não se adaptar, você tem a opção de ir pra outra. É. Muda de empresa sem mudar de emprego. (...) quer dizer se já é complicadíssimo para você mudar de área., de setor dentro de uma unidade, imagina o que que é você sair, por exemplo, do E\&P e ir para o ABAST ou sair do E\&P e ir pra área financeira. Deve ser o fim do mundo, né?! Deve ter que esperar uns dez anos pra isso." (Entrevistado 9)

“(...) Por exemplo, que se fala aqui na Empresa X, você pode ter vários empregos na mesma empresa, né?! Isso é completamente viável mesmo, porque a empresa é muito grande, tem diversas áreas, é possível ter uma mobilidade nacional e internacional... Enfim, você pode trabalhar em qualquer lugar desse. Beleza! É verdade. Agora muitas vezes na prática não acontece. Mas não vou dizer que na prática não acontece de forma alguma, não. Mas assim em muitas situações não acontece por quê? Porque o gerente acha que: "Não, só vou liberar...". (...) Foi dito isso. E eu consigo ver uma prática diferente em vários lugares. Conheço, tenho vários amigos que estão há muito tempo tentando mudar de área porque não estão satisfeitos ou não gostam mais do que estão fazendo, querem trabalhar com outras coisas, conseguem outras posições, articulam a coisa e o gerente simplesmente fala: "Não, daqui ninguém sai." Ou então já vi áreas que falam: "É regra aqui, nesta área, ninguém sai mais. Já vi isso. Então, e essa norma não existe na companhia. Não tem essa norma, né?! Não tem nada formal em relação a isso, mas chega assim um gerente executivo e fala: "Aqui nesta área ninguém mais sai, só se for para função gerencial." Enfim, sei lá. Então, assim, isso vai contra o discurso que é falado mesmo na empresa; na ambientação fala tudo isso: "Aqui você tem vários empregos, sem precisar sair da empresa, não sei o quê." É perfeitamente possível isso acontecer e deve acontecer em algumas áreas, mas também em outras áreas não acontece.” (Entrevistado 12)

"Não, na época, falaram, mas na prática isso não existe: essa mobilidade." (Entrevistado 10)

Ainda que, durante a Ambientação, regras e normas tenham sido expostas, os entrevistados entendem que na prática nem tudo se confirma.

As pessoas destacaram com bastante ênfase a falta de uniformidade no tratamento de questões corporativas. Isso se deve ao fato do grande poder de 
decisão que possuem os ocupantes de função gerencial. As normas existem, mas a aplicação varia de gerência para gerência, conforme destacam os entrevistados.

Pode-se verificar, assim, a existência de subculturas na Empresa X, a depender de cada gerência e das características daquele líder que ali está.

Preocupação com o ambiente, resultado, trabalho em equipe e tudo mais. Mas isso... essa questão de normas de horários, da falta de flexibilidade, às vezes... Tudo bem que tem um pouco, mas o problema é que esse um pouco varia de gerência para gerência. Às vezes causa um pouco de conflito. (...) Tem a norma para flexibilidade, mas o próprio gerente, digamos assim, é o dono dos seus empregados. Então, aí, a norma é ele quem faz. A norma, ele faz na prática. $\mathrm{O} \mathrm{RH}$, às vezes, não tem muito poder de influenciar os gerentes com relação à gestão dos seus empregados. Então, acaba gerando que cada gerência é uma norma; culturas diferentes, em alguns momentos... (Entrevistado 3)

"E os gerentes tem muito poder aqui: de fazer assim, fazer assado, sabe? Aí quando você fala: "Ah, essa cultura é de uma área, ou de uma gerência, de um cara que pensa assim..." Claro que ele pensa assim, que ele já viu isso em algum outro lugar aqui dentro. Cada área é uma empresa. Em cada área vai ter uma cultura um pouco diferente. Vai muito da cabeça do cara que está ali, naquele momento, né?! E aí, as pessoas que estão ali, vão se adaptar ou não. Não tem uma coisa tão padronizada assim. Então, você vai pegar várias experiências diferentes na companhia." (Entrevistado 12)

\section{b) Excesso de Autonomia dos Gerentes}

Mesmo que, durante a Ambientação, palestras tenham sido proferidas, inclusive sobre as possibilidades de carreira e desenvolvimento, os entrevistados, na prática, questionaram a aplicação dos critérios do avanço de nível bem como o nível de transparência do processo, alegando novamente excesso de autonomia dos Gerentes.

"Avanço de nível, ninguém olha. Ele nem olha isso. Quer nem saber como está o GD do cara. Ele fala: "Eu conheço, eu sei quem faz e quem não faz, sei quem merece e quem não merece." Não é o GD que vai dizer isso pra ele." (Entrevistado 10)

"É com relação ao avanço de nível. Que o discurso que se tem... Eles mostravam inclusive, isso de avanço de nível. Mas eu não 
lembro se eles falaram que era por meritocracia, etc., etc. Então, o discurso que se tem é que é a meritocracia e a visão que eu tenho é que isso não acontece desse jeito. Para mim, assim, os critérios do avanço de nível e promoção são muito claros. Estão lá muito claros, mas pra mim existe algo que faz com que todos os empregados cheguem ao final, no critério gerencial que a gente tem, com, mais ou menos, a mesma pontuação para o gerente decidir quem vai levar. (...) Os critérios são claros, a aplicação é que para mim não é clara. E, queria essa transparência. Tipo, não são cinco critérios? Então, faz um ranking dos cinco critérios, coloca um total no final para gente poder ver como isso aconteceu." (Entrevistado 2)

"É tudo basicamente questão de avanço de nível é... Claro que está nas mãos dos gerentes. (...) Eu não conheço. Não acho esse sistema transparente (...) Toda vez que tem pesquisa de ambiência, eu falo: Eu não acho transparente. Eu não entendo, por mais que eles expliquem, fica uma coisa, sabe, encoberta. Então, eu não sei. Não sei da onde vem essa verba ai..." (Entrevistado 14)

“(...) Em relação à cultura, eu acho que o outro problema assim é que: (...) Eu acho que os gerentes, às vezes, têm muita autonomia de decidir coisas que não estão alinhadas nas que são corporativas, sabe?" (Entrevistado 15)

O entrevistado 5 destacou que a influência partidária está presente na Cultura da Corporação e que nada foi dito durante o Programa de Formação de Empregados, reforçando a presença da política na cultura da Empresa. Para ele, por ser uma empresa do governo, a influência política é latente, especialmente, nas designações dos ocupantes de função gerencial.

“(...) A empresa, ela é muito política partidária. Isso foi lacônico no curso de formação. Deixaram a gente aprender da pior forma possível, com a experiência. Poderiam ter avisado a gente antes. Que a empresa é extremamente político-partidária. E existe política em vários sentidos: ela é do Governo, não é da União como ela deveria ser. Aí sim. Aí, eu não sou um cargo. Eu sou uma pessoa que tem que ser usado como recurso. O cara lá é uma instituição. Ele usa, às vezes, no sentido de, não digo do Presidente não, mas de todos os partidos que compõem a base $\mathrm{e}$ que influem na decisão das subidas, né?! Nas designações de cargo, de diretores... O que existe na Empresa $\mathrm{X}$ é que, como é uma empresa de quem está no Governo e o Governo muda a cada quatro anos, os gerentes, às vezes, se acham donos dos seus cargos também, né?! E as pessoas são da gerência, os cargos são 
da gerência. As pessoas são um cargo. Então, isso é muito ruim. O gerente, às vezes, ele é muito autocrático. Isso é uma força de conservação. Isso é errado. Não é errado, mas é antigo, entendeu?" (Entrevistado 5)

\section{c) Crescimento na Carreira e Desenvolvimento}

A variável política foi novamente apontada por vários indivíduos como grande influenciadora das possibilidades de crescimento na carreira, ainda que nada exista de forma declarada no Discurso da Companhia sobre essa variável, muitos destacaram que nem sempre há a prevalência de competências técnicas.

Aqui, os empregados ressaltam a política como característica da Cultura que não foi explicitada, transmitida pela organização de forma direta. Os empregados perceberam a existência dessa característica com o passar do tempo, quando já estavam alocados em suas respectivas áreas.

"Concordo que é uma super empresa. Eu não tenho dúvidas, né?! Só que o que eu comecei a pegar aqui é que, às vezes, você tem que tentar ficar agradando e agradando. Não é no sentido de fazer um trabalho bem feito. É de agradar, simplesmente, agradar, cair no gosto da pessoa.Se você não tiver empatia com outra pessoa, você não consegue avançar muito bem na sua carreira. Ou então, demora mais. Isso é uma coisa frustrante, mas infelizmente acontece em tudo quanto é lugar." (Entrevistado 2)

"Quando você está assumindo uma posição, você não assume só basicamente pela sua competência técnica, mas sempre com o viés do apoio de outra pessoa." (Entrevistado 4)

"Agora, existe a questão, dentro da cultura, do quem indica. Assim, trouxe uma pessoa para fazer determinada atividade, mas tinha aqui uma pessoa para fazer essa atividade. Para que trazer outra? Não, mas essa fui eu que trouxe." (Entrevistado 10)

"Não basta você ser bom, você tem que ter indicação. Então, assim, se não tiver alguém te olhando. Não, aquela menina ali é boa. Vamos dar uma oportunidade para ela. Não adianta."(Entrevistado 13)

"Pessoas de repente assumindo cargos que não estão preparadas para assumir tecnicamente. Até questão de perfil, porque você, para ser gerente, tem que ter perfil de um líder." (Entrevistado 7) 
Ratificando a influência da política na Cultura da Empresa X, alguns entrevistados demonstraram insatisfação quanto ao tempo que levaram para subir na carreira, especialmente quando se compararam à realidade do mercado. Isso também pode representar uma frustração uma vez que a Companhia prega no seu discurso a valorização do empenho por resultados.

"Pelo contrário, eu fui judiado e atrasado na minha carreira em dois anos. Em geral, um empregado junior leva quatro anos para chegar a pleno, eu levei seis. Foi no ano passado. É muito triste. No mercado, não acontece isso." (Entrevistado 5)

"Embora não seja uma empresa completamente pública, eu acho que ela carrega muito isso, sim. Tem muitas pessoas que você vê ai que estão ocupando determinados cargos, realizando determinadas atividades que - no papel existe uma exigência mas na prática você vê que se a pessoa cumpre $50 \%$ daquilo, é muito. (...) Olha, em relação à carreira, eu acho que é tudo muito amarrado e demorado, né?! Essa parte de carreira na Empresa X, na minha visão, ela anda muito diferente do mercado, né?! Que as pessoas hoje querem as coisas de forma mais rápida e muitas apresentam justificativas, realizam trabalhos, são merecedores, mas a empresa emperra isso. (...) Eu to aqui há seis anos, né?! Eu já levei no meu GD tudo dizendo superou as expectativas e eu não ganhei um nível." (Entrevistado 9)

\section{d) Meritocracia}

Para alguns, a meritocracia e a liderança são questionáveis, divergentes do Discurso na Companhia que privilegia Transparência e Resultados.

“É, tem que ter um ranking. Então... Assim, no fundo, no fundo... Você acaba muito que avaliando pela pessoa, né?! E o que eu via. Também era assim: ah esse ano você vai ser premiado, ano que vem você não vai, entendeu? Intercalavam. Não era uma coisa assim que... Era para deixar todo mundo feliz, entendeu?" (Entrevistado 6)

"Não tem meritocracia. Ele é igual para todo mundo. E aí, falam que GD conta para o avanço de nível. No final das contas o que vale é quem o gerente indicar. Ah, não... Tem uma parte que vem do GD, parte que vem do gerente e no final, o gerente indica ali quem ele quer para isso. O GD nem é tão determinante assim, não." (Entrevistado 12) 
“(...) Aquela questão da liderança responsável, entendeu? Do cara ser bom e ser um bom gestor. E, às vezes, eu vejo bons técnicos que não são bons gestores, entendeu? Às vezes, eu vejo gerentes gerais, no sentido ruim da palavra, entendeu? Assim, eu mando e tal. E eu acho que isso espelha muito no nosso dia-adia." (Entrevistado 10)

Para outros, ainda há oportunidades de carreira, inclusive com base no mérito, o que pode representar um fator motivacional de relevância para o empregado.

"Na verdade, eu estou em uma área da Engenharia que é muito boa de trabalhar. E assim: o mérito está em primeiro lugar. Têm os acomodados, mas eles também não são promovidos e fica por isso também, entendeu? Mas, assim, estou em uma área onde o merecimento está sempre em primeiro lugar. O reconhecimento pelo mérito." (Entrevistado 15)

"O que eu achei interessante também na Empresa X é isso. Esse lance de você ter carreira e ter crescimento e carreira gerencial. Esse é o lado que eu achava mais privado, assim, da empresa, que está ali no mercado. Então, têm que ter gerente, tem que ter gestores executivos, os caras que tocam aquele negócio. (...) $\mathrm{Na}$ Empresa $X$, você cresce na carreira, vira gerente, vira especialista. (...) Disso eu gostei e tem o lance de você, ao virar gerente, ter ganhos significativos de remuneração salarial e tal. Tudo isso para mim é motivação. E como eu tenho esse perfil mais de mercado assim, pelo histórico que eu vim, trabalhei em multinacional e tal. Essa coisa da carreira também, de possibilidade de crescimento e crescimento alto na carreira, isso para mim é muito interessante." (Entrevistado 12)

\section{d) Autonomia e Trabalho Desafiador}

A partir da rotina da Empresa, a visão dos entrevistados demonstra a coexistência de duas realidades, a depender da área onde cada entrevistado está lotado. Essa constatação reforça a existência de subculturas na Empresa X.

"Ah, sim. Eu acho que a gente tem bastante liberdade, né?! A gente tem autonomia. Eu acho assim que - pelo menos na área não industrial - as pessoas tem muito mais liberdade, né?! Tem muito mais acesso às informações e acesso ao gerente também, entendeu?" (Entrevistado 6)

"Não tem o negócio dos universitários lá? Que eles votam na Empresa X como empresa dos sonhos? Era isso que eu esperava, 
sabe? Uma empresa, onde eu iria ser super feliz, iria levantar todo dia e vir para cá super empolgada com o meu trabalho, iria me desenvolver assim, iria ver coisas diferentes, novas. Não estou dizendo que eu não vi. É óbvio que eu aprendi muito aqui, mas eu vejo colegas que são assim, que adoram o que fazem, que vem pra cá felizes e etc.. (...) para mim não foi assim, sabe?" (Entrevistado 1)

"O trabalho desafiador que aqui na minha vivência, na minha realidade não tem nada de desafiador, não. Assim, normal." (Entrevistado 7)

\section{e) Militarismo e Hierarquia}

O ditado popular: manda quem pode, obedece quem tem juízo parece ser uma realidade percebida e praticada por uma grande parte das empresas. Nesse ambiente, não há liderança e sim chefia e as decisões são centralizadas e discricionárias. Alguns entrevistados ressaltaram a cultura autocrática da Empresa $\mathrm{X}$, com resquícios da época do Militarismo, quando a hierarquia era a linha mestra.

"Do manda quem pode e obedece quem tem juízo. (Entrevistado 10)

(...) Então, assim, nossos gestores, é, alguns, né?! Principalmente, os mais velhos que vieram da cultura mais militar, pois havia uma cultura militar forte na Empresa X. A gente escuta muito isso. Mas eu acho que ela vem passando por transição e está mudando. Está em processo. (Entrevistado 12)

"A hierarquia, eu acho que ela tem que existir mesmo. Mas não emperrando o processo. E aí que vem o gestor. A hierarquia serve pra organizar um processo. Eu acho que ela é bem válida, mas existem gestores que emperram isso." (Entrevistado 10)

"Principalmente em refinaria. Quando eu sai do Cenpes e fui para uma Unidade do Abastecimento, a estrutura era hierárquica, assim, muito rígida. Eu não posso falar, por exemplo, direto com o chefe do meu chefe." (Entrevistado 14)

“(...) Hoje, eu já percebo um pouco mais como é que são as relações; como as relações se estabelecem. Por exemplo, eu não tenho essa coisa de hierarquia muito forte...Sou muito informal e eu recebi muitas criticas, no início, em função da minha informalidade." (Entrevistado 11) 


\section{f) Cumprimento de Expectativas}

Porquanto que a Empresa $\mathrm{X}$ não tenha prometido nada aos novos entrantes, expectativas foram criadas. A maior parte dos entrevistados concordou que, no geral, a Companhia conseguiu atender às suas expectativas.

\footnotetext{
"Acho que oitenta por cento." (Entrevistado 1)

"Eu acho que de certa forma sim.” (Entrevistado 3)

“Superou." (Entrevistado 4)
}

"Muito do que ela prometeu, ela cumpriu e muito bem cumprido, Para mim, até superou algumas expectativas e outras não." (Entrevistado 9)

“Superou.” (Entrevistado 13)

"Em grande parte sim." (Entrevistado 14)

"Superou mesmo." (Entrevistado 16)

Por outro lado, outros ressalvaram a insatisfação de não ter conseguido trabalhar com aquilo de que gostavam.

\footnotetext{
"Expectativa de trabalhar com que eu quero? No que eu gostava? Não." (Entrevistado 2)

“A atividade assim deixou um pouco a desejar." (Entrevistado 6)
}

\section{2.}

Análise do Programa de Formação de Empregados à luz das Teorias de Van Maanen

\section{a) Formal $x$ Informal}

Ainda que a Ambientação tenha por objetivo, além de dar as boas-vindas aos novos empregados e apresentar uma visão geral da Companhia, orientá-los quanto à postura desejada e disseminar a Cultura da Empresa, neste estudo, com base na teoria de Van Maanen (1978) sobre estratégias de socialização, o Programa não 
foi enquadrado como uma prática de socialização formal utilizada pela empresa. Dos 16 entrevistados, 13 entenderam que não houve um detalhamento formal de habilidades e atitudes esperadas pela empresa (VAN MAANEN, 1978) e, portanto, classificaram o Programa como uma estratégia de socialização informal.

“É, não tem algo formal, não. É informal isso. Tem um projeto para formalizar isso de certa forma, né?! Que é a gestão e competência individual específica, que vai mapear a competência. Esse projeto está com o a minha área e vai mapear competências, habilidades e atitudes." (Entrevistado 3)

"Informal, informal. Porque esse detalhamento ele não é feito nem em concurso público." (Entrevistado 5)

Reforçando esse entendimento, alguns entrevistados justificaram a sua posição levando em conta que grande parte do seu aprendizado ocorreu por experiência própria.

Entrevistador: Você acha que na empresa o seu papel, como recém-chegado, foi explicitado e enfatizado pela organização, com um detalhamento formal de habilidades e atitudes esperadas ou grande parte do teu aprendizado ocorreu por experiência própria?

“Ocorreu por experiência própria.” (Entrevistado 9)

"Não, não houve nada formal do que se esperava: minhas competências, nada disso. Vai, chegou... Você vai trabalhar com determinada coisa e vai aprendendo ali." (Entrevistado 12)

Para Van Maanen (1978), o processo formal prepara a pessoa para ocupar determinado status na organização, enquanto o informal prepara para assumir uma função. Nessa linha, a socialização formal geralmente ocorre anteriormente à informal. Na Informal, o recém-chegado é alocado em seu posto de trabalho na organização e deve aprender os processos desenvolvidos no seu departamento. A primeira parte trata de habilidades e atitudes gerais e a segunda de ações específicas e necessárias para desempenhar um papel na organização.

Dessa forma, quando há uma brecha separando os dois tipos de aprendizagem, pode haver uma desilusão com a socialização formal, levando o indivíduo a desconsiderar praticamente tudo o que ele aprendeu na parte formal da 
socialização, dado que o recém-chegado não consegue mais ver a relevância do seu treinamento inicial.

Isso pode ter acontecido, neste estudo, em razão do tempo decorrido após a realização do Programa de Formação de Empregados. Não há garantias de que o entendimento dos empregados na data da entrevista corresponda exatamente à percepção que tiveram na época da Ambientação e do Curso de Formação, pois algumas informações podem ter sido perdidas ao longo do tempo.

Além disso, na época em que os entrevistados participaram da Ambientação e do Curso de Formação, em 2006, não tinha sido criado o Projeto Cultura em Formação. Esse projeto foi criado em 2007 para tratar especificamente dos Valores, Comportamentos e Cultura da Empresa X, o que nos faz inferir de que havia uma lacuna nessa questão.

\section{b) Coletivo x Individual:}

Quando questionados se o processo de socialização do qual haviam participado deveria ser classificado como individual ou coletivo, a quase totalidade dos entrevistados (15) considerou que a socialização foi em massa, até mesmo em razão do processo seletivo da Empresa $\mathrm{X}$ naquele ano, em especial, ter recrutado uma grande quantidade de pessoas.

Entrevistador: Você foi introduzida ao trabalho individualmente com questões específicas para o teu cargo ou foi junto com grupo de novos membros reunidos, onde todos fizeram perguntas de forma coletiva?

"Coletiva. Uma maior galera foi contratada ao mesmo tempo." (Entrevistado 6)

"Não, foi com todo mundo. (...) eram oitenta pessoas... oitenta administradores." (Entrevistado 2)

Outros entrevistados reforçaram que a entrada inicial, inclusive, no local de trabalho também foi em conjunto com novos recém-chegados.

"Quando eu entrei, foi com outra colega da turma, e já tinham mais quatro da turma anterior, que tinham acabado de chegar e 
estavam esperando justamente a gente chegar para juntar e eles passarem tudo junto para a gente." (Entrevistado 14)

Para Van Maanen (1978), a socialização é coletiva quando os novos membros são reunidos e processados por experiências idênticas com resultados similares. No caso em estudo, pode-se inferir que os novos entrantes, ao passar pelo programa de socialização juntos, desenvolveram uma identificação um com o outro, uma consciência coletiva.

\section{c) Seqüencial x Não seqüencial:}

Van Maanen (1978) explica que na socialização seqüencial o indivíduo deve passar por uma série de fases para alcançar um papel definido e um status dentro da organização. Em uma socialização não seqüencial, o processo é alcançado em um único estágio transacional. Nesse caso, as técnicas não seqüenciais são realizadas provisoriamente e independem das relações com outras etapas anteriormente realizadas.

No caso da Empresa em estudo, 14 dos 16 entrevistados consideraram que o processo de socialização por que passaram foi marcado por uma série de etapas, ainda que - para alguns - a visão de carreira não tenha ficado tão bem entendida.

"Eu não sei se foi tão detalhado ... Mas eu me lembro do orientador do curso falando claramente: "olha, vocês vão ficar essas duas primeiras semanas aqui na FIRJAN, logo na primeira reunião que a gente teve. (...) Aí, você assina o contrato de trabalho. (...) E aí, na ambientação, onde começou a se falar como é que seria essa nossa introdução na Empresa $X$, no ambiente, na cultura da Empresa X... Foi ali que o orientador falou que a gente iria ter um programa de curso de formação; que a gente iria ter uma fase do vivencial; que a gente iria ter aquela ambientação; depois a gente iria ter um curso de formação; depois iria ter uma parte vivencial. "E, depois, viríamos direto para a área." (Entrevistado 2)

"Foi seqüencial. No próprio curso de formação, houve uma seqüência, desde o início até a distribuição das vagas. Depois, quando eu sentei na minha estação de trabalho, essa seqüência individualizada continuou. Fui apresentado à direção do 
compartilhado, fui apresentado às áreas de interface... e acho que foi seqüencial, sim.” (Entrevistado 8)

“É, eu acho que ele veio em etapas, mas a gente não tem a noção ainda ... Acho que, até hoje não tem, a noção de carreira, não. (...) $\mathrm{Eu}$ acho assim, que vem em etapas: primeiro você conhece o mundo Empresa X, depois você vem em uma escolinha, onde a gente passou pelos modos, depois você vai pra vaga que é outro processo, outra fase difícil. Aí, chega à área, entendeu? Mas daí pra você ter essa visão de carreira. Tipo assim, onde é que eu quero chegar. Não sei, talvez por ser muito grande, entendeu? E você desconhecer algumas áreas..." (Entrevistado 10)

\section{d) Fixo x Variável:}

Para Van Maanen (1978), os processos de socialização diferem quanto às informações e à certeza que o indivíduo tem sobre a mensuração do tempo que se leva para ocorrer uma transição. Processos fixos dão ao recrutado um conhecimento preciso do tempo que ele levará para completar um determinado estágio. Já em processos variáveis, não é dada a informação ao recrutado do tempo necessário para passar para outra fase.

No caso em estudo, os entrevistados (15), em sua maioria, foram informados do tempo necessário para passar de trainee para empregado, por exemplo.

"Acho que logo quando a gente entrou, o orientador falou que o curso de formação de administrador levava uns cinco meses, né?!" Então, foi dada a informação. (Entrevistado 8)

“É... (...), mas eu acho que foi meio torto, né?! Porque a gente iria ter o vivencial que cortaram em cima da hora, né?! Então, para gente deu esse ruído assim. A gente entrou achando que iam ser seis meses, né, mas foram quatro.” (Entrevistado 11)

Dessa forma, o entendimento geral foi de que o processo de socialização permitiu aos empregados, na época, conhecer o início e o fim de cada fase. Por outro lado, não houve relatos sobre o tempo necessário para ganhar uma promoção. Todavia, não podemos inferir que eles não tinham conhecimento desse tempo, apenas que nada foi relatado a respeito de crescimento na carreira. 


\section{e) Serial x Disjuntivo:}

A partir do momento em que os entrevistados foram alocados na área, a grande maioria (11) foi preparada por membros mais experientes para desempenhar suas funções.

“(...) foi um membro mais experiente que me ajudou."
(Entrevistado 7)

"Alguém que estava lá e estava tomando outras funções e eu compartilhava com ele." (Entrevistado 5)

"Alguém me treinou, mas não para assumir a função dele." (Entrevistado 16)

"Foi mais o gerente mesmo quem me ensinou." (Entrevistado 13)

"Quem me passou o treinamento foi um consultor contratado." (Entrevistado 9)

Enquanto que, para os demais entrevistados (5), não havia alguém disponível para mostrar o caminho a ser seguido. Nesse caso, eles tiveram que aprender sozinhos o trabalho que deveriam desempenhar. Segundo Van Maanen (1978), esse processo dá ao recém-chegado a oportunidade de ser inventivo e original, mas também pode proporcionar complicação e confusão para o recémchegado.

“(...) o da prática ninguém cuidou. Foi in the job. (...)Foi aquele negócio: chegou, tem que fazer: ah, como é que eu faço?Aí, você vai falando com o cara aqui do lado, com o outro ali e tal. Você vai vendo como tem que fazer o negócio ali." (Entrevistado 2)

"Na verdade, eu aprendi tudo basicamente sozinho, junto com o coordenador. (...) foi um caso particular porque quando eu cheguei aqui o coordenador não tinha equipe (...). Então, a gente fez, digamos assim... construiu a nossa coordenação... A coordenação com as atividades que a gente tem de certa forma até hoje, entendeu? Então, foi uma construção em conjunto; era uma coordenação bem nova." (Entrevistado 3) 
“(...) É disso que eu estou falando. A gente aprende mais sozinho. A pessoa fala assim: Agora você vai cuidar do GD. E ai, você vai cuidar e eu vim aqui para o Rio... E ai, entrei em um curso, olhava assim e ai tentava entender aquela ferramenta. Aprendi a mexer sozinha na ferramenta, entendeu?Não tive tutor, mentor, nada desses programas." (Entrevistado 10)

Dessa forma, no caso da empresa em estudo, a maior parte dos entrevistados classificou o processo de socialização por que passou como serial já que foram preparados por membros mais experientes para assumir suas funções na organização, ainda que não fossem as funções daqueles que os treinava. Para Van Maanen (1978), esse tipo de estratégia representa uma garantia de que a organização não vai mudar com o tempo, mas que, por outro lado, pode ser considerada uma estagnação, já que a forma de se fazer não muda, não há inovação.

\section{f) Por competição ou por Concurso:}

Os entrevistados foram questionados se o Programa de Formação do qual participaram representou mais uma estratégia de socialização por competição ou por concurso.

Considerando que - para Van Maanen (1978) - quando os recém-chegados são separados em programas distintos de socialização com base nas diferenças de habilidades, ambição ou experiência, o processo tem um aspecto competitivo. Já no processo contexto ou concurso, evita-se uma separação entre os recrutados, independentemente de idade, sexo e experiência. Nesse sentido, cada pessoa começa com igualdade com os outros participantes.

No caso da Empresa em estudo, 15 entrevistados classificaram o período em que estavam na Ambientação como uma estratégia por concurso, já que havia várias pessoas de diversas formações, não apenas administradores participando das palestras de apresentação da Companhia, sem discriminação de idade, sexo e experiência.

“Foi todo mundo junto, né?!”(Entrevistado 16)

“Tudo junto.” (Entrevistado 1) 
"Foi a segunda aí. Evitando-se a separação por..." (Entrevistado 5)

"Não houve separação, não. Eu vi tudo junto, todo mundo junto. Por habilidades não. Não houve separação, eu não me lembro em nenhum momento." (Entrevistado 9)

"Não, eu acho que é tudo junto. Não teve essa segregação, não. Porque lá a gente foi separado por curso, mas enfim... Acho que a formação mesmo, de administrador, não teve assim...O pessoal que é mais de orçamento. O pessoal que é mais de desempenho, o pessoal que é mais de $\mathrm{RH}$, não. Não, as habilidades anteriores..." (Entrevistado 10)

"Não. Não teve separação na ambientação. Depois a separação foi por cargo específico, né?! Mas ambientação todo mundo junto. Não teve separação por idade, nem por sexo." (Entrevistado 12)

\section{g) Por investidura ou Despojamento:}

Essas estratégias estão relacionadas ao grau em que a pessoa confirma sua identidade ou destrói para fazer parte da organização. Investidura ratifica e estabelece a viabilidade e a utilidade das características que a pessoa já possuía. Pode até mesmo não ser parte da identidade da empresa, mas algo que a empresa está precisando naquele momento. Por exemplo, as empresas contratam altos executivos pensando em como suas características pessoais podem ajudar a empresa. Por outro lado, os processos de desapropriação ou despojamento negam e recusam certas característica do novo entrante (VAN MAANEN, 1978).

Com base nessa teoria, uma minoria dos entrevistados entendeu que houve a confirmação do perfil individual de cada um na medida em que a organização levou em consideração o currículo no momento da distribuição e alocação das vagas.

"Não, ai que eu acho que na fase da entrevista, quando a gente manda os currículos, eles olham a nossa experiência anterior. Ai ela conta! Na hora da vaga!" (Entrevistado 10)

"Sim, foi. Foi a minha primeira opção, foi a primeira opção deles, foi um casamento perfeito assim..." (Entrevistado 11)

"Eu acho que houve nesse sentido porque a gente teve que 
elaborar um currículo, no qual você falava das tuas experiências, das tuas características, capacidades e tal. E também abriu espaço para o cara conhecer as áreas e escolher, na opinião dele, em quais ele gostaria de trabalhar. Então, a empresa levou sim em consideração o fato das áreas conheceram os perfis dos caras, através dos currículos, e ai, viram aqueles que se encaixariam melhor para as atividades e também se ouviu o empregado onde ele gostaria mais de trabalhar. Então acho que...(...) Ela buscou identificar quais são os perfis que existem e tentar colocar aquele perfil numa vaga que tivesse mais haver com o novo empregado. Esse esforço, eu acho que ela faz e acho que é bem legal." (Entrevistado 12)

Enquanto que os demais (10) classificaram o processo como uma estratégia de despojamento, já que entenderam que não foram escolhidos por suas características pessoais, e sim apenas alocados nas vagas conforme os interesses da organização.

"Foi o seguinte: eu não tinha gostado de nenhuma vaga. E essa vaga, ninguém tinha ido fazer a apresentação e ninguém sabia o que era. Então, ninguém a escolheu. Ai, eu falei: eu vou para essa aí. Não sei o que é. Foi assim..."(Entrevistado 16)

Entrevistador: No seu processo de socialização, a organização buscou confirmar o seu perfil utilizando as características que você já possuía...?

“Não, de jeito nenhum. Foi por despojamento.” (Entrevistado 5)

"Ah, eu sinto isso: que foi... adaptar o meu perfil, assim..." (Entrevistado 14)

“(...) procurou adaptar o meu perfil aos interesses dela." (Entrevistado 7)

"Não, não teve isso. Foi tudo no mesmo bolo e não importava o perfil de cada um na questão das destinações das vagas, né?! De repente, até com os nossos currículos, as áreas tentaram adaptar o perfil da gente com o perfil da área, mas, na maioria dos casos, não colou muito, não." (Entrevistado 13) 
6.

\section{Conclusão}

Este estudo teve como objetivo analisar se os valores transmitidos pela Companhia foram internalizados pelos empregados.

Para alcançar esse objetivo, estudou-se o caso de administradores que participaram juntos do processo de socialização de uma Empresa do Ramo de Energia, a Empresa X. Tanto a Ambientação quanto o Curso de Formação representaram táticas de socialização que visavam transmitir valores, normas, crenças e comportamentos.

A análise dos resultados da pesquisa foi dividida em quatro etapas: período anterior à entrada organizacional, período de participação na Ambientação e no Curso de Formação, período entre a alocação de fato na área e a data da entrevista e análise do processo de socialização sob a percepção dos empregados à luz das teorias de Van Maanen $(1978,1996)$.

No início das entrevistas, os empregados foram questionados sobre as expectativas reais antes da entrada na organização. Essas expectativas estão relacionadas a três categorias: fatores motivacionais para participar do processo seletivo público, imagem que tinham da Empresa e o que achavam que a Empresa esperava deles.

Com relação aos fatores motivacionais, foi possível observar que as expectativas das pessoas antes da entrada na organização mesclavam objetivos de carreira (trabalhar com o que gostam, atuar como nível superior; fatores circunstanciais ou relacionados ao ambiente de vida (ex: influência da família/amigos, estar procurando emprego), e vantagens que ela oferece (ex: estabilidade; salário).

A imagem que tinham da Empresa também foi importante para apoiar a decisão que haviam tomado de entrar na organização. Todos os empregados, de certa maneira, já tinham alguma informação sobre a Empresa até mesmo em razão da sua amplitude e diversidade de atuação. A imagem que tinham da empresa era positiva. Alguns a viam como a Empresa dos sonhos, uma Empresa que permite equilibrar vida profissional e pessoal e que oferece possibilidades de crescimento 
na carreira enquanto que outros a viam como uma Empresa com características similares ao setor privado, ágil e dinâmica.

A partir das entrevistas, podemos inferir que os entrevistados achavam que poderiam contribuir com a Empresa oferecendo os conhecimentos anteriores obtidos a partir da sua experiência profissional, e buscando trabalhar com dedicação, dinamismo e novas idéias.

Nessa primeira etapa da análise, foi possível inferir que os empregados ao aceitarem entrar na empresa, enxergavam que poderiam se encaixar no perfil desejável pela Companhia.

$\mathrm{Na}$ segunda etapa da análise, os entrevistados foram questionados especificamente sobre a Ambientação e o Curso de Formação. As respostas convergiram para o entendimento de que a Companhia, por meio desses dois momentos, buscou apresentar seus objetivos, valores, normas, crenças e comportamentos desejados em prol de uma identificação e confiança com os novos entrantes.

Os entrevistados concordaram que a socialização ajudou-os a conhecer melhor a Empresa, seu tamanho, áreas de negócio, interfaces e sua cultura. Também foi citado pelos entrevistados que o processo de socialização representou uma possibilidade de alinhar as expectativas dos novos entrantes às necessidades da Companhia.

Nessa linha, podemos inferir que a transmissão da cultura contribuiu para que os empregados compreendessem o funcionamento da Empresa $\mathrm{X}$ e buscassem se adaptar àquela realidade que se apresentava. Podemos inferir, também, que as experiências desse período contribuíram para consolidar um melhor alinhamento indivíduo-organização.

Considerando que a socialização interfere na relação entre o indivíduo e a organização, grande parte dos temas citados pelos entrevistados, tais como: nacionalismo, amor pela Empresa, qualidade de vida, preocupação com o empregado, gestão de Segurança, Meio Ambiente e Saúde, Segurança da Informação, Ética e Responsabilidade Social sugerem o esforço da Empresa em direcionar o comportamento dos empregados em prol de seus objetivos organizacionais, ou seja, a Empresa X, mediante o seu processo de socialização, buscava o alinhamento cultural de forma que o novo entrante se sentisse membro- 
participante da organização. Dessa forma, podemos considerar que tanto a Ambientação quanto o Curso de Formação foram processos de aprendizagem por meio dos quais os empregados puderem entender normas, valores e atitudes da Empresa X.

A intenção de assegurar a continuidade dos valores centrais e normas da Empresa $\mathrm{X}$ ficou mais evidente quando os entrevistados foram questionados sobre o perfil do empregado padrão. Segundo eles, a cultura da Empresa X direciona o empregado para adotar determinado comportamento. Para eles, o empregado padrão da Empresa X é aquele bem cuidado, compromissado, obediente e que tem orgulho da Empresa. Alguns entrevistados também ressaltaram que existe uma diferença entre o empregado que tem mais tempo de casa e o recém-chegado. Para eles, os empregados antigos tendem a ser mais avessos às mudanças, mais acomodados e menos dinâmicos. No entanto, não houve unanimidade quanto a esse entendimento, pois, em algumas áreas, essa diferença entre novos e antigos não foi confirmada, conforme a própria declaração dos entrevistados.

Podemos dizer que o processo de socialização foi importante na construção do perfil desse empregado padrão até porque segundo Fischer e Van Maanen (apud SAKS; GRUMAN, 2011, tradução nossa) a socialização organizacional foca em como os novos entrantes ajustarão suas condutas e aprenderão comportamentos, atitudes e habilidades necessárias para desenvolver suas funções e se encaixar como membro efetivo da nova organização.

Com relação ao período em que os empregados já estavam alocados nas suas respectivas áreas, o nível de engajamento e de alinhamento com os valores e normas foi tema relevante e bastante citado.

Vale ressaltar que o engajamento pode ser descrito como a chave direcionadora das atitudes, comportamentos e desempenho dos indivíduos (BATES, 2004; BAUMRUK, 2004; HARTER; SCHMIDT; HAYES,2002; RICHMAN, 2006, tradução nossa).

Nessa linha, os entrevistados argumentaram que a motivação de permanecerem na Companhia está relacionada a um conjunto de fatores: dinheiro, status, estabilidade, segurança do emprego e fazer o que gosta. Outros ainda argumentaram que estão simplesmente acomodados. 
Com base nas declarações acima, foi possível observar que os indivíduos são motivados tanto por fatores subjetivos (qualidade de vida, preocupação com pessoas, bom ambiente) quanto por fatores objetivos (salários, benefícios), conforme destacado nos estudos de Heslin (2003), Baruch (2004) e Lounsbury et al. (2004).

Quando perguntamos sobre os valores explícitos pela Companhia, as respostas foram quase unânimes. Os entrevistados compartilham desses valores, reconhecem a sua importância para a organização e entendem que o empregado da Empresa $\mathrm{X}$ deve segui-los.

Pode-se inferir que os valores transmitidos pela Companhia foram internalizados pelos empregados. Isso quer dizer que podemos considerar que a socialização conseguiu assegurar a continuidade dos valores centrais e normas. Podemos inferir também que os empregados se sentem membros-participantes da Empresa X. Há, possivelmente, um sentimento de pertencimento; de identificação, de forma geral, com os valores transmitidos explicitamente pela Empresa X, ainda que com algumas ressalvas da sua aplicação na prática.

Com relação à aplicação desses valores na prática, a literatura de Van Rekom, Van Riel e Wirenga (2006) reforça que os valores definidos pela ideologia não são necessariamente aqueles que efetivamente orientam o comportamento no dia-a-dia.

Ainda durante a terceira etapa da análise, os entrevistados também foram questionados quanto à coerência entre o discurso e a prática da Companhia. Eles destacaram algumas características da Empresa $\mathrm{X}$ referentes a valores e cultura organizacional. Para eles, alguns valores estão na Cultura, mas de forma velada; outros valores são patrocinados pela Companhia, mas na prática não podem ser observados e outros ainda diferem do que foi ideologicamente exposto pela Companhia.

Nesse contexto, as percepções dos indivíduos quanto à realidade que se apresenta podem interferir no alinhamento cultural tão desejável pela Companhia, especialmente quanto aos valores que não estão explícitos.

No caso de decepções nos indivíduos, causadas pelas divergências entre o discurso e a prática da Companhia, perdas de produtividade e motivação no trabalho podem ocorrer. 
Para O’Reilly, Chatman e Caldwell, (1991), o alinhamento indivíduoorganização está associado a níveis decrescentes de rotatividade de pessoal e a altos níveis de satisfação no trabalho, comprometimento e atração. Ou seja, o desalinhamento pode aumentar a probabilidade de resultados negativos.

Entre os pontos destacados pelos entrevistados em que a prática não condiz com os conceitos de valores ideologicamente patrocinados, tem-se:

a) A empresa anunciou durante a Ambientação que, por ser uma empresa de grande porte, com muitas possibilidades, seria possível trabalhar em vários lugares/setores. No entanto, a prática não se confirmou, pois, ainda que haja regras, o poder de decisão está nas mãos dos Gerentes, conforme declarações de alguns dos entrevistados;

b) As pessoas destacaram com bastante ênfase a falta de uniformidade no tratamento de questões corporativas. Isso se deve ao fato do grande poder de decisão que possuem os ocupantes de função gerencial. As normas existem, mas a aplicação varia de gerência para gerência, conforme destacam os entrevistados.

c) Mesmo que, durante a Ambientação, palestras tenham sido proferidas, inclusive sobre as possibilidades de carreira e desenvolvimento, os entrevistados, na prática, questionaram a aplicação dos critérios do avanço de nível bem como o nível de transparência do processo, alegando novamente excesso de autonomia dos Gerentes. Adicionalmente, a variável política foi novamente apontada por vários indivíduos como grande influenciadora das possibilidades de crescimento na carreira e da aplicação da meritocracia. Muitos destacaram que nem sempre há a prevalência de competências técnicas.

d) A influência partidária está presente na Cultura da Corporação, talvez de forma velada. Nada foi dito durante o Programa de Formação de Empregados sobre a presença da política na cultura da Empresa. Os empregados ressaltaram a política como característica da Cultura que não foi explicitada, ou seja, transmitida pela organização de forma direta. Os empregados perceberam a existência dessa característica com 
o passar do tempo, quando já estavam alocados em suas respectivas áreas;

e) Os entrevistados também destacaram a influência do Militarismo e da Hierarquia nas relações do dia a dia ainda que nada tenha sido explicitado durante o processo de socialização;

A última etapa da análise se refere à classificação do processo de socialização da Empresa X com base nas teorias de Van Maanen $(1978,1996)$ segundo a percepção dos entrevistados.

Para eles, o Programa de Formação de Empregados da Empresa $\mathrm{X}$ foi classificado como informal já que não houve um detalhamento formal de habilidades e atitudes esperadas pela Empresa. Foi alegado também que grande parte do aprendizado de alguns ocorreu por experiência própria.

Quando questionados se o processo de socialização do qual haviam participado deveria ser classificado como individual ou coletivo, a maioria considerou que a socialização foi em massa, até mesmo em razão do processo seletivo da Empresa $\mathrm{X}$ naquele ano, em especial, ter recrutado uma grande quantidade de pessoas. Outros entrevistados reforçaram que a entrada inicial, inclusive, no local de trabalho também foi junto com novos recém-chegados.

Com relação às fases do processo de socialização, a maioria dos entrevistados considerou que a socialização por que passaram foi marcada por uma série de etapas, ainda que - para alguns - a visão de carreira não tenha ficado tão bem entendida.

Para os entrevistados, o processo de socialização também pode ser classificado como fixo já que a maioria foi informada do tempo necessário para passar de trainee para empregado, por exemplo. Por outro lado, não houve relatos sobre o tempo necessário para ganhar uma promoção. Todavia, não podemos inferir que eles não tinham conhecimento desse tempo, apenas que nada foi relatado a respeito de tempo necessário para o crescimento na carreira.

Quando questionados se o processo de socialização deveria ser classificado como serial ou disjuntivo, a maior parte dos entrevistados classificou a socialização como serial já que foram preparados por membros mais experientes 
para assumir suas funções na organização, ainda que não fossem as funções daqueles que os treinava.

Quanto à estratégia adotada, se competição ou concurso, a maioria classificou o período em que estavam na Ambientação como uma estratégia por concurso, até porque havia várias pessoas de diversas formações, não apenas administradores participando das palestras de apresentação da Companhia, sem discriminação de idade, sexo e experiência.

Quanto ao grau de adaptação e/ou aproveitamento do perfil do novo entrante, a maioria classificou processo como uma estratégia de despojamento uma vez que entenderam que não foram escolhidos por suas características pessoais, e sim apenas alocados nas vagas conforme os interesses da organização. 
7.

\section{Considerações Finais}

Podemos verificar ainda que o processo de socialização do empregado na empresa $\mathrm{X}$ não se restringiu à Ambientação e ao Curso de Formação, pois a socialização continuou após o término do Curso e o início do trabalho de fato. Segundo Feldman (1976), o desenvolvimento de habilidades necessárias para o trabalho é uma das partes do processo de socialização. Na Empresa X, a compreensão do papel a ser desempenhado pelos novos empregados só ocorreu após o término do Curso de Formação, com sua alocação em uma gerência da empresa.

Por fim, a partir das respostas dos entrevistados, foi possível verificar a coexistência de realidades distintas, a depender da área onde cada entrevistado está lotado. Essa constatação reforça a existência de subculturas na Empresa X. 


\section{8. \\ Referências bibliográficas}

ACEVEDO, José M.; YANCEY, George B. Assessing new employee orientation programs. Journal of Workplace Learning, Bingley, v. 23, n. 5, p. 349-354, 2011.

AKTOUF, Omar. O simbolismo e a cultura da empresa: dos arcabouços conceituais às lições empíricas. In: CHANLAT, Jean F. (Org.). O indivíduo na organização: dimensões esquecidas. São Paulo: Atlas, 1994. v. 2.

ALLEN, N. J.; MEYER, J. P. Organizational socialization tactics: a longitudinal analysis of links to newcomers commitment and role orientation. Academy of Management Journal, [S.1.], v. 4, p. 847-858, 1990.

ANDERSON, E.; OLIVER, R. L. Perspectives on behavior-based versus outcome-based salesforce control systems. Journal of Marketing, [S.1.], v. 51, p.76-88, out. 1987.

ASHFORTH, B.E.; MAEL, F. Social identity and the organization. Academy of Management Review, [S.1.], v. 1, p. 20-39, 1989.

ASHFORTH, B. E.; SAKS, A. M. Socialization tactics: longitudinal effects on newcomer adjustment. Academy of Management Journal, [S.1.], v. 1, p. 149$178,1996$.

BARRETT, Richard. Libertando a alma da empresa: como transformar a organização numa entidade viva. São Paulo: Cultrix, 2000.

Building a values-driven organization: a whole system approach to cultural transformation. Oxford: Elsevier, 2006.

BACKHAUS, Kristin. Importance of person-organization fit to job seekers. Career Development International, [S.1.], v. 8, n. 1, p. 21-26, 2003.

BOOG, Gustavo; CASADO, Tânia; DUTRA, Joel. Título. In: JORNADA PROSPECTIVA DE RH, 1., 2006, Rio de Janeiro. Anais... Rio de Janeiro: Petrobras, 2006.

BAUMRUK, R. The missing link: the role of employee engagement in business success. Workspan, [S.1.], v. 47, p. 48-52, 2004.

BATES, S. Getting engaged. HR Magazine, [S.1.], v. 49, no. 2, p. 44-51, 2004.

BOXX, W. R.; ODOM, R. Y.; DUNN, M. G. Organizational values and value congruency and their impact on satisfaction, commitment and cohesion. Public Personnel Management, [S.1.], v. 20, p. 195-205, 1991. 
BARUCH, Y. Transforming careers: from linear to multidirectional career paths: organizational and individual perspectives. Career Development International, [S.1.], v. 9, n. 1, p. 58-73, 2004.

BAUER, T. N.; MORRISON, E. W; CALLISTER, R. R. Organizational socialization: a review and directions for future research. Research in Personnel and Human Resource Management, [S.1.], v. 16, p. 149-214, 1998.

BHARGAVA, S.; MATHUR, R. An empirical study on transforming 21st century organizations through values. In: BI-ANNUAL CONFERENCE OF THE INTERNATIONAL SOCIETY FOR THE STUDY OF WORK AND ORGANIZATIONAL VALUES, 8., 2002, [S.1.]. Proceedings... [S.1.]: [s.n.], 2002.

BILHIM, João Abreu de Faria. Gestão estratégica de recursos humanos. 3. ed. Lisboa: Instituto Superior de Ciências Sociais e Políticas, 2007. ISBN 972-872671-6.

BORGES, L. de O. et al. A síndrome de burnout e os valores organizacionais: um estudo comparativo em hospitais universitários. Psicologia: reflexão e crítica, Porto Alegre, v. 15, n. 1, p. 189-200, 2002.

CABLE, Daniel M.; PARSONS, Charles K. Socialization tactics and person organization fit. Personal Psychology, [S.1.], v. 54, p. 1-23, 2001.

CABLE, D. M.; JUDGE, T. A. Person-organization fit, job choice decisions and organizational entry. Organizational Behavior \& Human Decision Processes, [S.1.], v. 67, p. 294-311, 1996.

CARLESS, S. A. Person-job fit versus person-organization fit as predictors of organizational attraction and job acceptance intentions: a longitudinal study.

Journal of Occupational and Organizational Psychology, [S.1.], v. 78, p. 411429, 2005.

CHAO, G. T. et al. Organizational socialization: its content and consequences. Journal of Applied Psychology, Washington, DC, v. 79, no. 5, p. 730-743, 1994.

CHATMAN, J. A. Improving international organizational research: a model of person-organization fit. Academy of Management Review, [S.1.], v. 14, n. 3, p. 333-349, 1989.

Matching people and organizations: selection and socialization in public accounting firms. Administrative Science Quarterly, [S.1.], v. 36, p. 459-484, 1991.

Matching people and organizations: selection and socialization in public accounting firms. Administrative Science Quarterly, [S.1.], v. 36, n. 3, p. 459484, 1991. 
CRESWELL, J. W. Projeto de pesquisa: métodos qualitativo, quantitativo e misto. 2. ed. Porto Alegre: Artmed, 2007.

CHRISTENSEN, Edward W.; GORDON, George G. An exploration of industry, culture and revenue growth. Organization Studies, [S.1.], n. 3, p. 397-422, 1999.

COOPER-THOMAS, Helena D.; ANDERSON, Annelies; VAN VIANEN, Neil. Changes in person: organization fit: the impact of socialization tactics on perceived and actual $\mathrm{P}-\mathrm{O}$ fit. European Journal of Work and Organizational Psychology, [S.1.], v. 13, n. 1, p. 52-78, 2004.

CORTES, Leonardo Lopes; SILVA, José Roberto Gomes. Construção do contrato psicológico de indivíduos que ingressam em organizações do setor público no atual contexto brasileiro: estudo de caso em uma empresa Estatal. [S.1.]: EnANPAD, 2006.

DUTTON, J. E.; DUKERICH, J. M.; HARQUAIL, C. V. Organizational images and member identification. Administrative Science Quarterly, [S.1.], v. 2, p. 239-263, 1994.

DE BAKER. S. Hire Power de. Best's Review, [S.1.], v. 109, n.1, 2008.

DUTRA, Ivan; SOUZA, Maria José Barbosa; FELIX, Luiz Antônio. Pesquisa de marketing. Londrina, 2003. Apostila da disciplina Organizações e mercado, Mestrado em Administração, Programa de Pós-Graduação AUEM, Universidade Estadual de Londrina.

ELFENBEIN, H. A.; O'REILLY III, C. A. Fitting in: the effects of relational demography and person-culture fit on group process and performance. Group Organization Management, [S.1.], v. 32, 2007.

EMPRESA X. Plano Estratégico da Empresa X 2020. Rio de Janeiro, 2011. 2011. Projeto Estratégico de Recursos Humanos 2007/2008. Rio de Janeiro,

FELDMAN, Daniel Charles. A contingency theory of socialization.

Administrative Science Quarterly, [S.1.], v. 21, 1976.

FLICK, Uwe. An introduction to qualitative research. 4. ed. London: Sage Publications, 2009.

FOGARTY, Timothy J. Socialization and organizational outcomes in large public accounting firms. Journal of Managerial Issues, [S.1.], v. 12, 2000.

FREITAS, M. E. de. Cultura Organizacional: formação, tipologias e impactos. São Paulo: Makron, 1991. 
GARAVAN, Thomas N.; MORLEY, Michael. The socialization of high- potential graduates into the organization: initial expectations, experiences and outcomes.

Journal of Managerial Psychology, [S.1.], v. 12, n. 2, p. 118-137, 1997.

GE, Jianhua; SU, Xuemei; SHOU, Yan. Organizational socialization, organizational identification and organizational citizenship behavior: an empirical research of chinese high-tech manufacturing enterprises. Nankai Business

Review International, [S.1.], v. 1, n. 2, p.166-179, 2010.

GIL, Antonio Carlos. Como elaborar projetos de pesquisa. 4. ed. São Paulo: Atlas, 2002.

GONÇALVES, Cristina Faria Fidelis. Estatística. Londrina: Ed. UEL, 2002.

HARTER, J. K.; SCHMIDT, F. L.; HAYES, T. L. Business-unit level relationship between employee satisfaction, employee engagement and business outcomes: a meta-analysis. Journal of Applied Psychology, [S.1.], v. 87, p. 268-279, 2002.

HESLIN, P. A. Self and other referent criteria of career success. Journal of Career Assessment, [S.1.], v. 11, n. 3, p. 262-286, 2003.

HOFFMAN, B. J; WOEHR, D. J. A quantitative review of the relantionship between person-organization fit and the behavioral outcomes. Journal of Vocational Behavior, v. 68, n.3, p. 389-399, 2006.

HOFSTEDE, Geert. Attitudes, values and organizational culture, disentangling the concepts. Organization Studies, [S.1.], v. 19, n. 3, p. 477-492, 1998.

HOFSTEDE, G. H. Cultures and organizations: software of the mind. New York: McGraw-Hill Book Company, 1991.

HOFSTEDE, Geert. et. al. Measuring organizational cultures: a qualitative and quantitative study across twenty cases. Administrative Science, [S.1.], n. 35, p.286-316, 1990.

HOLTON III, Elwood F.; RUSSELL, Craig J. The relationship of anticipation to newcomer socialization processes and outcomes: a pilot study. Journal of Occupational and Organizational Psychology, [S.1.], v. 70, p. 163-172, 1997.

JOHANN, Silvio Luiz. Gestão da cultura corporativa: como as organizações de alto desempenho gerenciam sua cultura organizacional. 3. ed. São Paulo: Saraiva, 2006.

JONES, G. R. Socialization tactics, self-efficacy and newcomers adjustments to organizations. Academy of Management Journal, [S.1.], v. 2, p. 262-79, 1986.

JUDGE, T. A.; CABLE, D. M. Applicant personality, organizational culture and organization attraction. Personnel Psychology, [S.1.], v. 50, n. 2, p. 359-394, 1997. 
KABANOFF, B.; DALY, J. Espoused values of organizations. Australian Journal of Management, [S.1.], v. 27, p. 89-97, 2002.

KIM, T. Y.; CABLE, D. M.; KIM, S. P. Socialization tactics, employee proativity and person-organization fit. Journal of Applied Psychology, [S.1.], v. 2, p. 232$240,2005$.

KLENKE, K. Corporate values as multi-level, multi-domain antecedents of leader behaviors. International Journal of Manpower, [S.1.], v. 26, n. 1, p. 50-68, 2005.

KRISTOF, A.L. Person-organization fit: an integrative review of its conceptualizations, measurement, and implications. Personnel Psychology, [S.l.], v. 49, p. 1-49, 1996.

LAUVER, K.J.; KRISTOF-BROWN, A. Distinguishing between employees' perceptions of person-job fit and person-organization fit. Journal of Vocational Behavior, [S.1.], v. 59, p. 454-470, 2001.

LOPEZ, Tará; MCMILLAN-CAPEHART, Amy. Elements of salesperson control: an organizational theory perspective. Journal of Business \& Industrial Marketing, [S.1.], v. 24, no. 2, p. 98-107, 2009.

LOUIS, Merly Reis. Surprise and sense making: what newcomers experience in entering unfamiliar organizational settings. Administrative Science Quartely, [S.1.] n. 25, p. 226-251, jun. 1980.

LOUNSBURY, J. W. et. al. Personality, Career satisfaction and life satisfaction: test of directional model interests. Journal of Career Assessment, [S.1.], v. 12, n. 4, p. 395-406, 2004.

MAEL, F. A.; TETRICK, L.E. Identifying organizational identification. Educational and Psychological Measurement, [S.1.], v. 4, p. 813-24, 1992.

MEGLINO, B. M.; RAVLIN, E. C. Individual values in organizations: concepts, controversies and research. Journal of Management, [S.1.], v. 24, n. 3, p. 295330, 1998.

MENGUC, Bulent; HAN, Sang-Lin; AUH, Seigyoung. A test of a model of new salespeople's socialization and adjustment in a collectivist culture. Journal of Personal Selling \& Sales Management, [S.1.], v. 27, no. 2, p. 149-167, 2007.

MICHAILOVA, S.; HUTCHINGS, K. National cultural influences on knowledge sharing: a comparison of China and Russia. Journal of Management Studies, [S.1.], v. 43, n. 3, p. 383-405, 2006.

MILLER, V. D; JABLIN, F. M Information seeking during organizational entry: influences, tactics, and a model of the process. Academy of Management Review, [S.1.], v. 1, p. 92-120, 1991. 
MINTZBERG, Henry. Safari da Estratégia: um roteiro pela selva do planejamento estratégico. Porto Alegre: Bookman, 2000.

MORGAN, Gareth. Imagens da organização. Tradução: Cecília Whitaker Bergamini, Roberto Coda. São Paulo: Atlas, 1996.

OLIVEIRA, F. A., TAMAYO, A. Inventário de perfis de valores organizacionais. Revista de Administração, [S.1.], v. 39, n. 2. p. 129-140, 2004.

O'REILLY, C. A. Corporations, culture, and commitment: motivation and social control in organizations. Management California Review, [S.1.], v. 31, n. 4, p. 9$25,1989$.

O'REILLY, C. I.; CHATMAN, J.; CALDWELL, D. People and organizational culture: a profile comparison approach to assessing person-organization fit. Academy of Management Journal, [S.1.], v. 34, p. 487-516, 1991.

Organizational commitment and psychological attachment: the effects of compliance, identification, and internalization on prosocial behavior. Journal of Applied Psychology, [S.1.], v. 71, p. 492-499, Aug.1986.

OUCHI, W.; MAGUIRE, M. A. Organizational control: two functions, Administrative Science Quarterly, [S.1.], v. 20, p. 559-569, Dec. 1975.

POSNER, B. Z. Person-organization values congruence: no support for individual differences as a moderating influence. Human Relation, [S.1.], v. 45, n. 4, p. 351$361,1992$.

PETTIGREW, A. On studying organizational cultures. Administrative Science Quarterly, [S.1.], v. 24, p. 570-581, 1979.

PETTIGREW, A. M. A Cultura das organizações é administrável? In: FLEURY, M. T. L., FISCHER, R. M. Cultura e Poder nas Organizações. Editora Atlas, 1996.

RICHMAN, A., Everyone wants an engaged workforce: how can you create it? Workspan, [S.1.], v. 49, p 36-39, 2006.

RICHARDOSN, Roberto Jarry. Pesquisa social. 2 ed. São Paulo: Atlas, 1989.

RYAN, A. M.; SCHMIT, M. J., An assessment of organizational climate and a PE fit: a tool for organizational change. International Journal of Organizational Analysis, [S.1.], v. 4, n. 1, p. 75-95, 1996.

ROUSSEAU, D.; PARKS, J. The contracts of individuals and organizations. In CUMMINGS, L. L.; STAW, B. M. (Eds). Research in organizational behavior. Greenwich, CT: JAI Press, 1992. v. 15, p. 1-47. 
SAKS, A. M.; ASHFORTH, B. E. Organizational socialization: making sense of the past and present as a prologue for the future. Journal of Vocational

Behavior, [S.1.], v. 51, p. 234-279, 1997.

SAKS, Alan M.; GRUMAN, Jamie A. Getting newcomers engaged: the role of socialization tactics. Journal of Managerial Psychology, [S.1.], v. 26, no. 5, p. 383-402, 2011.

SANTOS, Vânia Martins dos Santos; SILVA, Adriana Oliveira da Silva; CALDERÓN, Patrícia Asunción Loaiza. Estratégias de Socialização: a forma mais eficaz para a integração entre indivíduo e organização. In: SIMPÓSIO DE EXCELÊNCIA EM GESTÃO E TECNOLOGIA, [2012?], [S.1.]. Anais... [S.1.]: UNIGRANRIO, [2012?].

SCHEIN, E. H. Coming to a new awareness of organizational culture, Sloan Management Review, [S.1.], v. Winter, p. 3-16, 1984.

SCHEIN, Edgar H. Organizational Culture and Leadership. San Francisco: Jossey Bass, 1992.

Organizational culture and leadership. [S.1.]: Jossey-Bass, 1989. Organizational socialization and the profession of management. Industrial Management Review, Cambridge, Mass., v. 9, p. 1-15, 1968.

SCHNEIDER, B. The people make the place. Personnel Psychology, [S.1.], v. 40, n. 3, p. 437-53, 1987.

SHERIDAN, John E. Organizational culture and employee retention. The academy of Management Journal, [S.1.], v. 35, n 5, p. 1036-1056, 1992.

SHINYASHIKI, Gilberto Tadeu. Socialização organizacional: implicações na gestão de recursos humanos. In: INTERNATIONAL CONFERENCE OF IBEROAMERICAN ACADEMY OF MANAGEMENT, 3rd. São Paulo, 2003. Anais... São Paulo: [s.n.], 2003.

SILVERTHORNE, Colin, The impact of organizational culture and personorganization fit on organizational commitment and job satisfaction in Taiwan. Leadership \& Organization Development Journal, [S.1.], v. 25, no. 7, p. 592599, 2004.

SMIRCICH, Linda. Concepts of culture and organizational analysis.

Administrative Science Quartely, [S.1.], n. 28, p. 339-355, set. 1983.

TAMAYO, A.; BORGES, L. Valores del trabalho e valores de las organizaciones. In: ROS, M.; GOUVEIA, V.V. Psicologia Social de los Valores Humanos: desarrolos teóricos, metodológicos y aplicados. Madri: Biblioteca Nueva, 2000. 
Valores do trabalho e das organizações. In: ROS, M.; GOUVEIA, V. V. Psicologia social dos valores humanos. Desenvolvimentos teóricos, metodológicos e aplicados. São Paulo: SENAC, 2006.

TAMAYO, A; MENDES, A. M.; PAZ, M. G. T. Inventário de valores organizacionais. Estudos de Psicologia, [S.1.], v. 5, n. 2, p. 289-315, 2000. TEIXEIRA, Sebastião. Gestão das Organizações. 2. Ed. [S.1.]: McGraw Hill, 2010.

TEVES, Nilda. Diagnóstico de cultura organizacional. Rio de Janeiro: Empresa $\mathrm{X}, 2005$.

TICHY, Noel M. Managing change strategically: the technical, political and cultural keys. Organizational dynamics, [S.1.], n. 9, p. 59-80, 1982.

TOMEI, Patrícia Amélia; RUSSO; Giuseppe Maria; ANTONACCIO, Carla F. Bottino. Cultura Empreendedora: guia prático para seleção de empreendedores. Rio de Janeiro: Office Book Editora, 2008.

TROMPENAARS, F. Nas ondas da cultura: como entender a diversidade cultural nos negócios. São Paulo: Educator, 1994.

VAN MAANEN, Jon. People processing: strategies of organizational socialization. [S.1.]: Organizational Dynamics, 1978.

Processando as pessoas: estratégias de socialização organizacional. In: FLEURY, Maria Teresa Leme [et al]. Cultura e poder nas organizações. São Paulo: Atlas, 1996.

VAN MAANEN, Jon; SHEIN, E. H. Toward a theory of organizational socialization. In STAW, M. B.; CUMMINGS, L. L. (Ed.). Research in organizational behavior. Greenwich, Conn.: JAI Press, 1979. v. 1, p.209-264.

VAN REKOM, J.; VAN RIEL; C. B. M.; WIRENGA, B. A methodology for assessing organizacional core values. Journal of Management Studies, Oxford, v. 43, n. 2, p. 175-201, mar. 2006.

WANOUS, J. P; REICHERS, A. E. New employee orientation programs. Human Resource Management Review, [S.1.], v. 10 n 4, p. 18-36, 2000. 


\section{APÊNDICE A - ROTEIRO SEMI-ESTRUTURADO DE ENTREVISTA}

Finalidade da Pesquisa: Coletar subsídios para analisar se os valores discursados pela Companhia foram internalizados pelos empregados após o processo de socialização, decorridos aproximadamente seis anos da participação no Programa de Formação de Empregados (Ambientação e Curso de Formação).

\section{Perfil do Respondente}

a) Nome e formação e Idade; Tempo de Empresa X, Experiência prévia;

b) É ou já foi chefe? Por quanto tempo?

c) Já pensou em sair da empresa? Se sim, por que pensou nisso?

d) Consegue se ver trabalhando por um longo tempo na Companhia? Pretende se aposentar pela empresa?

Categoria 1: Expectativas do entrevistado antes da entrada na organização

a) Por que se inscreveu no concurso público para esta empresa? Quais eram suas expectativas sobre a Empresa? O que buscava?

b) Qual era a imagem que você tinha da Empresa?

c) O que você achava que a Empresa esperava de você? Como você achava que poderia contribuir para o crescimento da Empresa?

Categoria 2: Validade da Ambientação e do Curso de Formação

a) Como foi participar da Ambientação? Como foi participar do Curso de Formação? Agregou valor, conhecimento, te ajudou a se familiarizar com a Empresa X?Valeu à pena?

Se não houvesse este programa faria diferença? Por quê?

Categoria 3: Conteúdo da Ambientação e do Curso de Formação

a) Quais e que tipo de informações você recebeu durante a Ambientação (perfil da Empresa, cultura, valores, crenças e normas) e durante o Curso de Formação?

b) Do que você se lembra sobre o que a empresa pregava como valores organizacionais durante as palestras? E sobre Cultura Empresa X? E sobre Imagem da Empresa? Exemplifique

c) Durante a ambientação e durante o Curso de Formação se exemplificava o que era considerado um comportamento desejado/esperado pela Companhia ou o comportamento de um "empregado padrão Empresa X"?

Categoria 4: Identificação com os Valores Organizacionais e com os Comportamentos

a) O que é ser empregado padrão Empresa $X$ para você? Você se considera um?

b) Você se sente identificado com a Companhia? Com a cultura Empresa X, com os valores e com as normas?

c) O que te fez ficar até hoje na Companhia?
( ) Senso de Dever
( ) Patriotismo 
( ) Fazer o que gosta

( ) Acreditar no trabalho

( ) Orgulho da Companhia

( ) Autonomia para trabalhar

( ) Falta de opção

( ) Outro:

d) Você acha que é esperado do empregado padrão Empresa $X$ que ele se comporte/atue com base nos preceitos de desenvolvimento sustentável (desenvolvimento econômico e social e meio ambiente saudável), respeito à vida (excelência nas questões de saúde, segurança e meio ambiente), da diversidade humana e cultural (respeito às diferenças, não discriminação e igualdade de oportunidades), transparência e ética?

e) Você acha que é esperado do empregado padrão Empresa X que ele busque trabalhar em equipe?

f) Você acha que é esperado do empregado padrão que ele busque atingir resultados (geração de valor para as partes interessadas, com foco em disciplina de capital e gestão de custos)?

g) E quando ele atinge um determinado resultado, com alto desempenho, você acha que ele espera ser valorizado e reconhecido de forma diferenciada?

h) Você acha que é esperado do empregado padrão Empresa $X$ que ele esteja pronto para mudanças e aceite a responsabilidade de inspirar e criar mudanças positivas?

i) Você acha que é esperado do empregado padrão Empresa $\mathrm{X}$ que ele seja empreendedor (supere desafios) e inovador?

j) Você acha que o empregado padrão espera da Companhia que ela invista nele e no seu desenvolvimento?

k) Você acha que é esperado do empregado padrão Empresa $X$ que ele sinta orgulho de trabalhar na Empresa X?

1) Você acha que é esperado do empregado padrão Empresa $X$ que ele siga o exemplo dos seus Líderes (Gerentes, Coordenadores)?

Categoria 5 : Categoria: Comparação entre Discurso versus Prática

a) Os valores acima citados, as normas e crenças preconizadas durante as palestras puderam ser observados por você nesses anos? O que você consegue perceber que foi dito, mas não pôde ser observado e/ou sentido por você após ter sido alocado na área? Você percebeu incoerência, diferença e/ou dissonância entre o discurso e a prática, ou seja, o que foi discursado pela Companhia durante o programa de socialização pode ser observado no dia a dia?

b) Acredita que a Companhia cumpriu com o que prometeu, as suas expectativas foram atendidas? Se não, o que faltou?

Categoria 6 : Sobre as práticas de socialização a luz das teorias de Van Maanen: 
Para Van Maanen, há sete pares de estratégias de socialização empregadas pelas empresas, podendo ser combinadas de diversas formas. Entre elas, citam-se: Formal ou Informal, Individual ou Coletiva, Seqüencial ou Não seqüencial, Fixa ou Variável, Serial ou Disjuntiva, por competição ou por concurso, investidura ou despojamento.

Com base na sua experiência, o programa de socialização da Empresa $X$ composto pela: Ambientação (Dimensão Institucional) e pelo Curso de Formação (que inclui a Dimensão Técnica, a Vivencial, a Gestão de Negócios, a Distribuição de Vagas, a Formatura até a Alocação Inicial), e ainda o tempo de trabalho efetivo na área:

a) Você acha que na empresa o seu papel, como recém-chegado, foi explicitado e enfatizado pela organização, com um detalhamento formal de habilidades e atitudes esperadas ou grande parte do teu aprendizado ocorreu por experiência própria? (Formal x Informal)

b) Quando você entrou na empresa, você foi introduzido ao trabalho individualmente com questões específicas para o teu cargo, ou com o grupo dos novos membros reunidos, onde todos fizeram perguntas de forma coletiva? (Individual ou Coletivo)

c) O seu programa de socialização foi marcado por uma série de etapas identificáveis, ou seja, foi dado ao recém-chegado um caminho bem entendido para a sua carreira dentro da organização ou o programa de socialização foi alcançado em um único estágio transacional? (Seqüencial e não Seqüencial)

d) O tempo do seu programa de socialização (ambientação, curso de formação até a alocação inicial) tinha início e fim determinados ou não foi dada a informação do tempo necessário de cada fase? (Fixo ou Variável)

e) No seu caso, você foi preparado por um membro mais experiente para assumir a função dele na organização ou foi a área de Recursos Humanos quem cuidou sozinha de todos os aspectos do treinamento? (Serial ou Disjuntivo)

f) $\mathrm{Na}$ época da sua socialização, os recém-chegados foram separados em programas diferentes de socialização com base nas habilidades, ambição ou experiência ou houve uma participação e cooperação maior entre os indivíduos, evitando-se uma separação entre os recém-chegados, independentemente de idade, sexo e experiência? (por Competição ou por Concurso)

g) No seu processo de socialização, a organização buscou confirmar o seu perfil, utilizando as características que você já possuía ou a organização procurou adaptar o seu perfil aos interesses dela, ou seja, seus valores antigos e identidades pessoais foram desfeitos e substituídos por novos? (Por investidura ou Por despojamento) 